\title{
12. SITE 634: NORTHWEST PROVIDENCE CHANNEL ${ }^{1}$
}

\author{
Shipboard Scientific Party ${ }^{2}$
}

\section{HOLE 634A}

Date occupied: 3 March 1985, 1500 EST

Date departed: 8 March 1985, 1845 EST

Time on hole: 5 days, $3 \mathrm{hr}, 45 \mathrm{~min}$

Position: $25^{\circ} 23.02^{\prime} \mathrm{N}, 77^{\circ} 18.88^{\prime} \mathrm{W}$

Water depth (sea level; corrected m, echo-sounding): 2835 (includes $13^{\circ}$ slope correction)

Water depth (rig floor; corrected m, echo-sounding): 2846

Bottom felt ( $m$, drill pipe): 2867

Total depth (m): 3343

Penetration (m): 479.4

Number of cores: 32

Total length of cored section (m): 322.5 (including two washed intervals)

Total core recovered $(\mathrm{m}): 27.3$

Core recovery $(\%): 8.5$

Oldest sediment cored:

Depth sub-bottom (m): 479.4

Nature: chert, chalk, and limestone

Age: early Campanian

\footnotetext{
${ }^{1}$ Austin, J. A., Jr., Schlager, W., Palmer, A. A., et al., 1986. Proc., Init. Repts. (Pt. A), ODP, 101

2 James A. Austin Jr. (Co-Chief Scientist), Institute for Geophysics, University of Texas at Austin, Austin, TX 78751; Wolfgang Schlager (Co-Chief Scientist), Rosenstiel School of Marine and Atmospheric Sciences, Miami, FL 33149 (current address: Vrije Universiteit, Instituut v. Aardwetenschappen, Postbus 7161, 1007 MC Amsterdam, Netherlands); Amanda A. Palmer, Staff Scientist, Ocean Drilling Program, Texas A\&M University, College Station, TX 77843; Paul A. Comet, The University, Newcastle-Upon-Tyne, Newcastle, United Kingdom (current address: Core Labs Singapore, 24A-Lim Teck Boo Rd., Singapore 1953); André Droxler, Rosenstiel School of Marine and Atmospheric Sciences, Miami, FL 33149 (current address: Department of Geology, University of South Carolina, Columbia, SC 29208); Gregor Eberli, Geologisches Institut, ETH-Zentrum, Zürich, Switzerland (current address: Fisher Island Station, University of Miami, Miami, FL 33139); Eric Fourcade, Laboratoire de Stratigraphie, Université Pierre et Marie Curie, 4 Place Jussieu 75230, Paris Cedex 05, France; Raymond Freeman-Lynde, Department of Geology, University of Georgia, Athens, GA 30602; Craig S. Fulthorpe, Department of Geological Sciences, Northwestern University, Evanston, IL 60201; Gill Harwood, Department of Geology, The University, Newcastle-Upon-Tyne, NE1 7RU United Kingdom; Gerhard Kuhn, Geologisches Institut Göttingen, Federal Republic of Germany (current address: Alfred Wegener Institut für Polarforschung, Columbus Center, D-2850 Bremerhaven, West Germany); Dawn Lavoie, NORDA Code 363, Seafloor Geosciences Division, NSTL, MS 39529; Mark Leckie, Woods Hole Oceanographic Institution, Woods Hole, MA 02543 (curren address: Department of Geology and Geography, University of Massachusetts, Amherst, MA 01003); Allan J. Melillo, Department of Geological Sciences, Rutgers University, New Brunswick, NJ 08903 (current address: Chevron U.S.A., New Orleans, LA 70114); Arthur Moore, Marathon Oil Company, P.O. Box 269, Littleton, CO 80160; Henry T. Mullins, Department of Geology, Syracuse University, Syracuse, NY 13210; Christian Ravenne, Institut Français du Pétrole, B.P. 311, 92506 Rueil Malmaison Cedex, France; William W. Sager, Department of Oceanography, Texas A\&M University, College Station, TX 77843; Peter Swart, Fisher Island Station, University of Miami, Miami, FL 33139 (current address: Marine Geology and Geophysics, Rosenstiel School of Marine and Atmospheric Sciences, Miami, FL 33149); Joost W. Verbeek, Dutch Geological Survey, P.O. Box 157, 2000 A.D. Haarlem, Netherlands; David K. Watkins, Department of Geology, University of Nebraska, Lincoln, NE 68588; Colin Williams, Borehole Research Group, Lamont-Doherty Geological Observatory, Palisades, NY 10964.
}

Measured velocity $(\mathrm{km} / \mathrm{s}):>5.0$, Hamilton Frame, with wide scatter; 2.87 , average interval velocity on regional seismic profiles

Principal results: Site 634 in Northwest Providence Channel was occupied from 3 through 8 March 1985 . One hole was drilled at $25^{\circ} 23.02^{\prime} \mathrm{N}$, $77^{\circ} 18.88^{\prime} \mathrm{W}$, in $2835 \mathrm{~m}$ water depth. Hole $634 \mathrm{~A}$ penetrated to $479 \mathrm{~m}$ with a rotary bit. The interval from 6 to $144 \mathrm{~m}$ below seafloor (mbsf) was washed because the site is less than $500 \mathrm{~m}$ from DSDP Site 98. Recovery in the cored intervals was $5.8 \%$. Site 634 was an attempt to deepen DSDP Site 98 to what is commonly called the "megabank," the mid-Cretaceous platform thought to underlie both Bahama banks and basins. The site had to be abandoned above this target because of poor hole conditions.

The following sequence was penetrated: (1) Units I and II, 0-6 m sub-bottom; periplatform ooze with some chalk and hardgrounds, late Pliocene to Pleistocene in age; (2) Unit III, 144-182 m sub-bottom; nannofossil chalk with chert nodules, late Paleocene to early Eocene in age; and (3) Unit IV, 182-479 m sub-bottom; alternation of nannofossil chalk and detrital limestones with some chert. Limestones consist of skeletal grainstones and rudstones, interpreted as turbidites, and of breccias with pebble-sized clasts of shallow-water limestones in chalk matrix, tentatively interpreted as debris flows; proportions of these lithologies are poorly known because of low recovery; age is early to late Campanian.

The basal unit of chalk and sediment gravity flows probably represents the debris apron of a carbonate platform. This apron grades upward into a carbonate slope that was bypassed by turbidity currents and on which carbonate ooze accumulated slowly (with several hiatuses). The transition from basin floor to slope may reflect the combined effects of upbuilding of the Cretaceous Bahama Bank and the downward cutting of the nearby Great Bahama Canyon.

The tie between borehole stratigraphy and seismic profiles is good and leads to a revision of the ages of two prominent reflectors. The reflector at $140 \mathrm{~m}$ sub-bottom is early Eocene rather than Oligocene, and the one at $280 \mathrm{~m}$ sub-bottom is late Campanian rather than early Eocene.

Compensated neutron and gamma-spectroscopy logs run in the pipe provide detailed information on porosity and basin lithologies that largely compensates for poor core recovery.

\section{BACKGROUND AND OBJECTIVES}

\section{Background}

\section{Introduction}

Both Sites 634 and 635 probably would not have been drilled during ODP Leg 101 had the top of the interpreted mid-Cretaceous "megabank" been penetrated either at Site 626 (BAH-1-C) or at Site 632 (BAH-11-C). Site 634 constituted a reoccupation of DSDP Site 98 (Hollister, Ewing, et al., 1972). Permission to deepen this site to an inferred buried platform top had been granted prior to DSDP Leg 76.

Site 635 (BAH-3-A) was located in the thalweg of Northeast Providence Channel (the Great Bahama Canyon of Andrews et al., 1970) approximately $2 \mathrm{n}$. mi northwest of Site 98, where the inferred platform top beneath DSDP Site 98 either cropped out or was shallowly buried and therefore easily accessible. BAH-3-A was an alternate site, to be drilled only if time was available at the end of the leg and/or if more deeply buried shallow-water carbonates could not be recovered at either Site 626 or 632 . Both eventualities occurred during Leg 101. 


\section{Discussion}

The scientific importance of dating the drowning of carbonate platforms worldwide and the consequent implications for the geologic history of the Bahamas have already been explained (see "Background and Objectives" sections for Sites 626, 627, and 631 chapters). Results at both Sites 626 and 627 tended to support the "megabank" hypothesis for the origin of Bahamian banks and troughs (Paulus, 1972; Sheridan et al., 1981). However, failure to sample the section below $300 \mathrm{~m}$ sub-bottom in Exuma Sound because of the presence of migrating hydrocarbons prevented calibration of long-range seismic stratigraphic correlations (J. Ladd and R. Sheridan, unpubl. data).

One of these correlations tied Exuma Sound stratigraphy to that beneath the Straits of Florida through Northwest and Northeast Providence channels (Sheridan et al., 1981; J. Ladd and R. Sheridan, unpubl. data; Fig. 1). Site 634 was designed to provide ground truth along these tie-lines by deepening Site 98 to the acoustic surface-velocity discontinuity interpreted by Sheridan et al. (1981) as the top of an Albian-Aptian carbonate platform.

Site 98 intermittently sampled an Upper Cretaceous (upper Santonian-lower Campanian) to Holocene section down to 357 m sub-bottom. The Cretaceous rocks were bioclastic turbidites containing perireef limestone (Hollister, Ewing, et al., 1972; Fig. 2). Velocity information from multichannel seismic lines in the vicinity of Site 98 suggested that the sub-bottom depth of the platform there was approximately $800 \mathrm{~m}$ and that seismic recognition of the platform on the flanks of Northeast Providence Channel was rather poor (see "Seismic Stratigraphy" section, this chapter). In contrast, Site 635 (BAH-3-A) provided excellent acoustic recognition of the top of the platform (at approximately $150-200 \mathrm{~m}$ sub-bottom). In spite of these advantages, Site BAH-3A was rated lower than BAH-3 because of its location directly in the axis of one of the world's largest submarine canyons (Andrews et al., 1970; Fig. 3). Not only would spudding in be difficult in possible talus accumulations, but the platform top itself might be eroded, effectively preventing calibration of its submergence and subsequent subsidence. In contrast, a deep-penetration attempt at BAH-3 (near Site 98) would increase the chances of recovering a complete and well-dated section across the inferred mid-Cretaceous drowning event. Therefore, Site 635 was drilled only after poor hole conditions terminated Site 634 approximately $300 \mathrm{~m}$ short of the platform top (see "Sedimentology," "Biostratigraphy," "Seismic Stratigraphy," and "Summary and Conclusions" sections, this chapter).

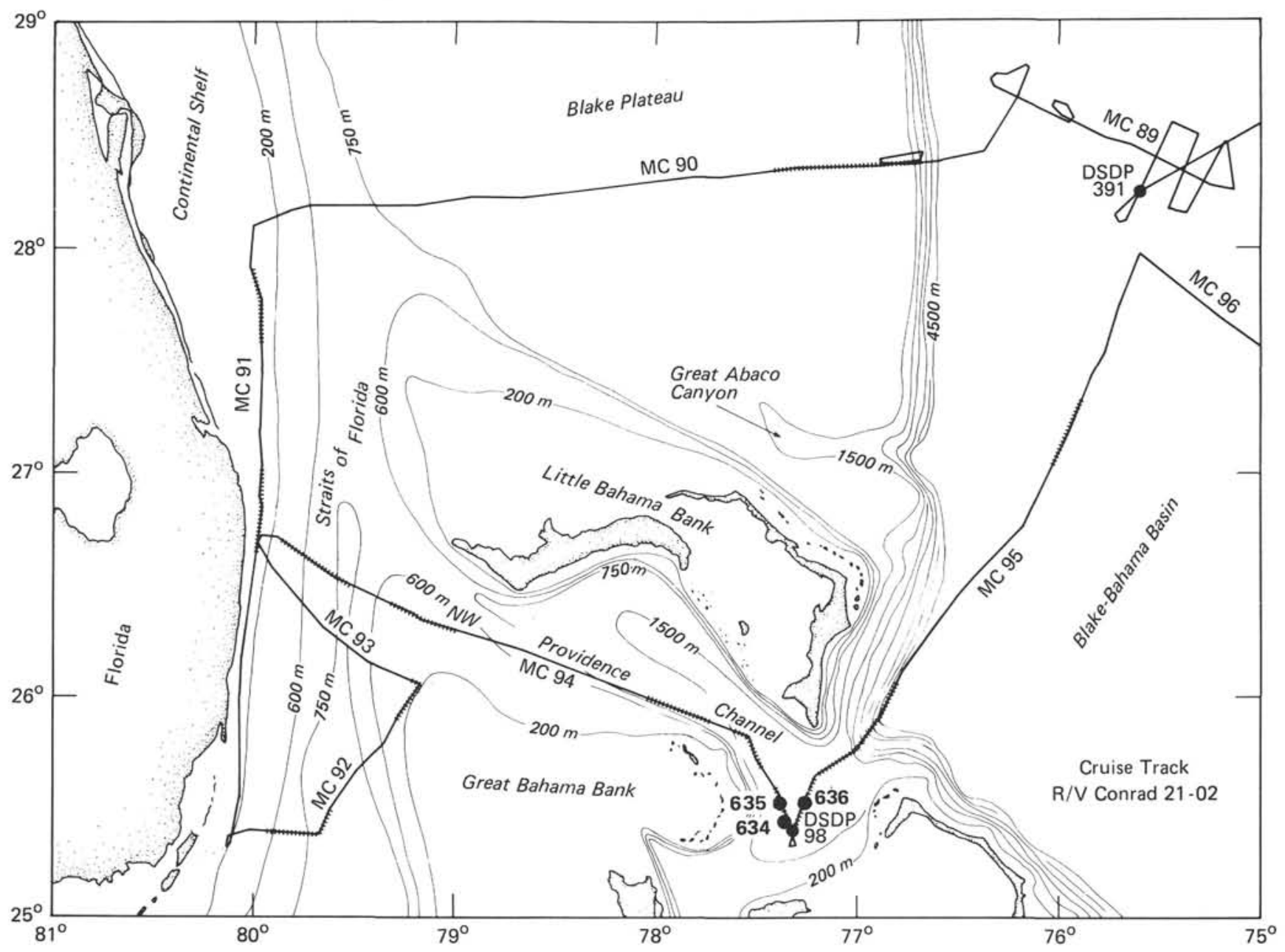

Figure 1. Location map of multichannel seismic-reflection lines in the vicinity of DSDP Site 98 and ODP Sites 634, 635, and 636. After Sheridan et al. (1981). 


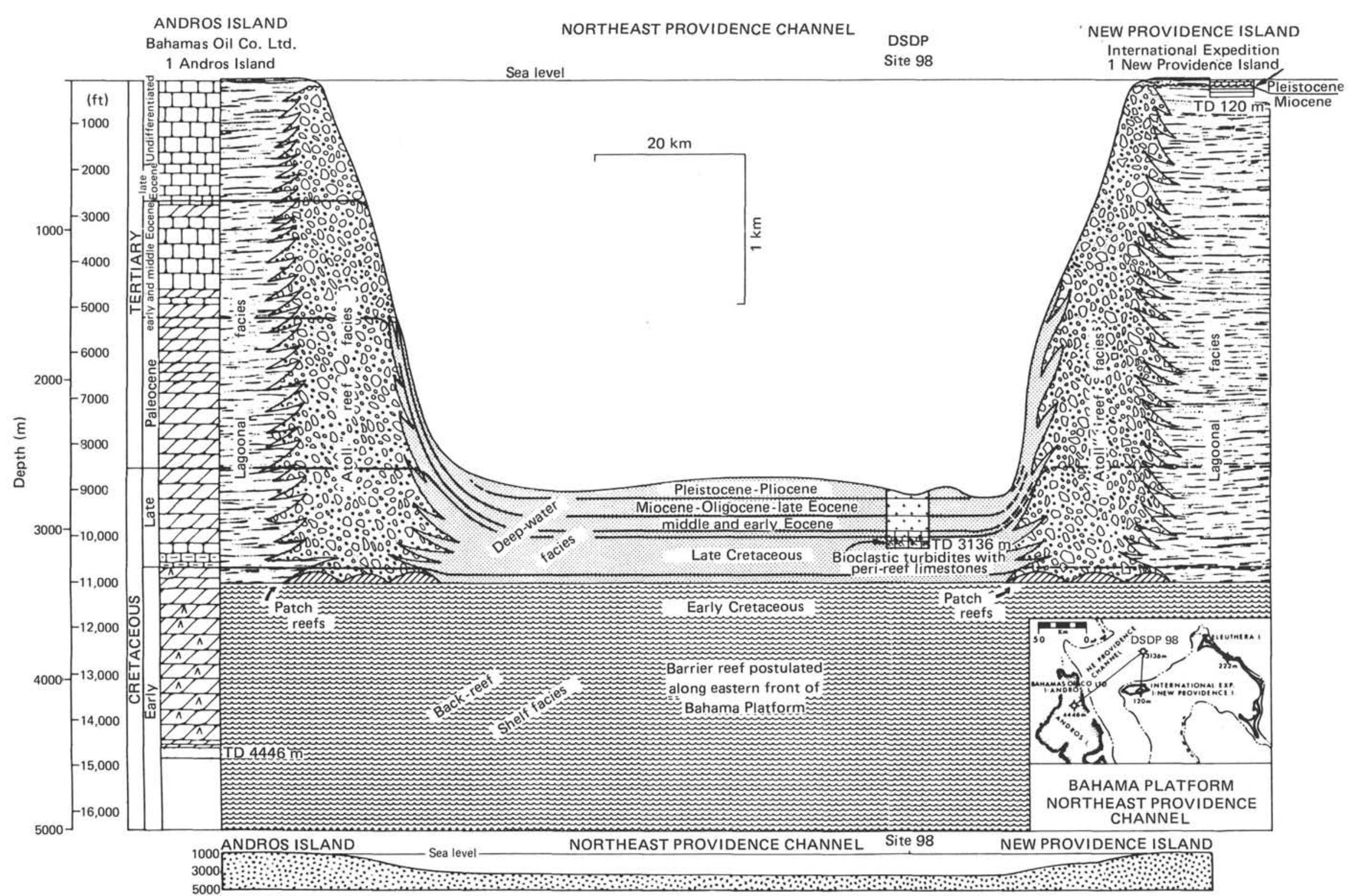

Figure 2. Cross section of a part of the Bahama Platform through DSDP Site 98 from Andros Island to New Providence Island, showing the relationships of shallow-water bank and shelf facies to the deep-water channel facies. Time lines are based on ages from the Andros Island well and Site 98. After Paulus (1972). 


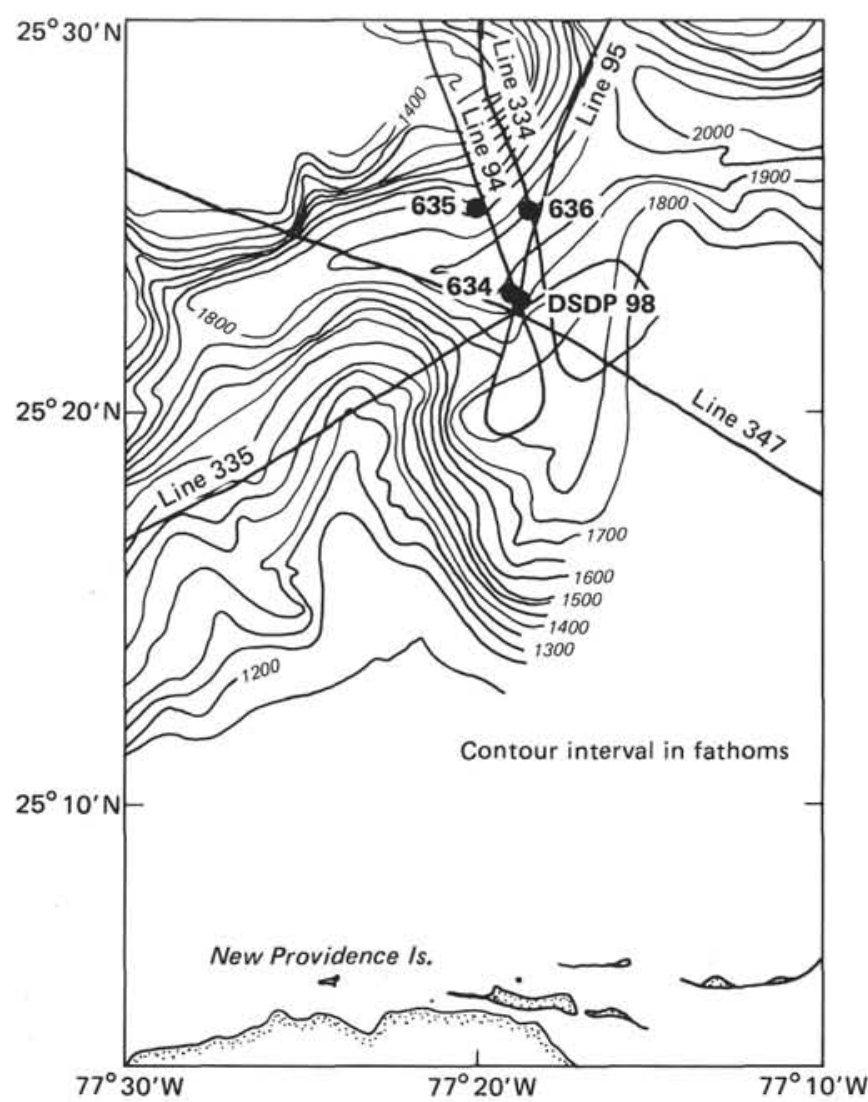

Figure 3. Locations of Sites 634,635 , and 636 relative to regional seismic coverage in Northeast Providence Channel.

\section{Objectives}

Drilling at both Sites 634 and 635 was designed to address the following questions:

1. What is the geologic significance of the prominent acoustic horizon velocity discontinuity beneath Northeast Providence Channel? Does it represent the top of a drowned shallow-watercarbonate platform?

2. What is the age and nature of platform drowning in the vicinity of Northeast Providence Channel? How do sediments at Sites 634 and 635 compare with the section recovered at Site 627 ?

3. If drowning occurred in both places at the same time, as suggested by the "megabank" hypothesis, why does the platform top sit at approximately $1.5 \mathrm{~km}$ depth north of Little Bahama Bank (Site 627) and at roughly $3.6 \mathrm{~km}$ in the vicinity of DSDP Site 98 ?

4. Are the long-range seismic stratigraphic correlations through this part of the Bahamas valid? Are the interpreted ages of so-called regional acoustic horizons in this location consistent with those sampled by Leg 101 north of Little Bahama Bank and in Exuma Sound?

5. Is the platform top eroded? Can such erosional episodes be related to seismic signatures on multichannel lines collected near Site 635 ?

\section{OPERATIONS SUMMARY}

The JOIDES Resolution approached DSDP Site $98\left(25^{\circ}\right.$ $22.95^{\prime} \mathrm{N}, 77^{\circ} 18.68^{\prime} \mathrm{W}$ ) from the northeast in the early afternoon of 3 March after an 18-hr transit from Exuma Sound. After reducing speed to $4 \mathrm{kt}$, the ship turned west at $1258 \mathrm{hr}$ and crossed the site at $1316 \mathrm{hr}$. Navigation was by satellite, LORAN $\mathrm{C}$, and radar bearings off New Providence Island approximately $15 \mathrm{n}$. mi to the south (Fig. 3). After turning around, drill pipe was run in the hole (RIH) to a depth of $2754 \mathrm{~m}$ while a final approach was made. A beacon was dropped at $1500 \mathrm{hr}$, and the ship's position was stabilized (within a radius of $30 \mathrm{~m}$ ) by 1530 hr. The Site 634 position is as follows: $25^{\circ} 22.973-23.057^{\prime} \mathrm{N}$, $77^{\circ} 18.830-920^{\prime} \mathrm{W}$ (the range of good SATNAV fixes obtained on site), approximately $0.2 \mathrm{n}$. mi west-northwest (downslope, on the eastern flank of Northeast Providence Channel) of the Site 98 location. The water depth measured on the $12-\mathrm{kHz}$ system was $2755 \mathrm{~m}$ (uncorr.), $2761 \mathrm{~m}$ (corr.), but a slope angle of $13^{\circ}$ estimated from nearby multichannel seismic line 334 (Fig. 3) resulted in an additional correction of $+74 \mathrm{~m}$ for a corrected water depth of $2835 \mathrm{~m}$ and $2846 \mathrm{~m}$ to the rig floor. The water depth at Site 98 was $2750 \mathrm{~m}$ (corr.).

A successful mud-line rotary core was retrieved at $0320 \mathrm{hr}, 4$ March, from a sub-rig floor depth of $2867 \mathrm{~m}$. At that point, washing commenced to a depth of $144 \mathrm{~m}$ sub-bottom, where competent sediments necessitated pulling the center bit at $0840 \mathrm{hr}$. A wash core (Core 634A-2R, 144.0-153.6 m sub-bottom) recovered $7.2 \mathrm{~m}$ of indurated chalk and intercalated nodular chert at $1130 \mathrm{hr}$, and the decision was made to core continuously from that point.

Round-trip times between cores averaged less than $1.5 \mathrm{hr}$ through Core $634 \mathrm{~A}-11 \mathrm{R}$ at $239.6 \mathrm{~m}$ sub-bottom. Sediment recovery was generally less than $15 \%$, particularly after sand and chert fragments began to fill in around the drill-bit assembly during coring of Core 634A-6R (182.1-191.5 m sub-bottom). By Core 634A-14R (258.2-267.8 m sub-bottom), $20 \mathrm{bbl}$ of mud was being used every $20 \mathrm{~m}$ to condition the hole. From Core $634 \mathrm{~A}-11 \mathrm{R}$ to Core $634 \mathrm{~A}-21 \mathrm{R}$, intervals between cores lengthened to more than $2 \mathrm{hr}$.

After no recovery at all in Cores 634A-17R through 634A-21R (287.1-335.3 $\mathrm{m}$ sub-bottom), the decision was made to wash either to the base of the section sampled at DSDP Site $98(357 \mathrm{~m}$ sub-bottom) or until the sediments became competent enough to sample effectively. A center bit was reinserted into the drill string, and washing commenced to $354.6 \mathrm{~m}$ sub-bottom. When Core 634A-22R (354.6-364.2 m sub-bottom) recovered $0.6 \mathrm{~m}$ of early Campanian lithified grainstones at $0340 \mathrm{hr}, 6 \mathrm{March}$, continuous coring commenced again. However, recovery in Cores $634 \mathrm{~A}-22 \mathrm{R}$ through $634 \mathrm{~A}-26 \mathrm{R}$ to a sub-bottom depth of $402.5 \mathrm{~m}$ averaged only $2.9 \%$.

In order to save additional time in a part of the section that continued to show such poor recovery, permission was requested and granted to core only once for every two core lengths of section penetrated. Cores $634 \mathrm{~A}-27 \mathrm{R}$ and $634 \mathrm{~A}-28 \mathrm{R}$ each sampled $19.3 \mathrm{~m}$ of section (402.5-441.1 m sub-bottom), and average recovery improved to $6.0 \%$, so continuous coring began once more. Sloughing of unconsolidated material into the well bore continued throughout this interval, and as much as $40 \mathrm{bbl}$ of mud was used intermittently to control the sloughing. It was necessary also to pull the bit $50 \mathrm{~m}$ above the bottom of the hole in order to keep the drill string clear before recovery of Core 634A-28R.

While cutting Core 634A-31R (460.3-469.9 m sub-bottom) between 2100 and $2200 \mathrm{hr}, 6 \mathrm{March}$, the pipe became stuck, and an overpull of $100,000 \mathrm{lb}$ was necessary to free it. Circulation was reestablished only after pulling out of the hole $(\mathrm{POOH})$ about $40 \mathrm{~m}$. After retrieving Core 634A-31R at $0130 \mathrm{hr}$, $7 \mathrm{March}$, a center bit was used to redrill the plugged interval, and an additional $20 \mathrm{bbl}$ of mud was used to condition the hole. This operation was completed by $0745 \mathrm{hr}$.

Unfortunately, the pipe became stuck again while cutting Core 634A-32R (469.9-479.4 m sub-bottom), and the decision then was made to abandon further drilling attempts at this location. Core 634A-32R came on deck at $1010 \mathrm{hr}, 7$ March. 
The drill string was $\mathrm{POOH}$ to $421 \mathrm{~m}$ sub-bottom in order to clear all obstructions, and Hole $634 \mathrm{~A}$ was displaced with prehydrated gel as a hole-conditioning agent prior to logging. No outof-pipe logging was attempted at Site 634 because of the poor hole conditions. Logging (compensated neutron, natural gamma ray, and an experimental gamma spectroscopy tool) in the pipe began at $1330 \mathrm{hr}, 7 \mathrm{March}$. Both the compensated neutron tool and the natural gamma ray were run from the mud line to $421 \mathrm{~m}$ sub-bottom. The gamma spectroscopy tool then was run between 140 and $300 \mathrm{~m}$ sub-bottom, an interval of particular interest for both regional seismic and geologic correlations.

Logging continued until approximately $1700 \mathrm{hr}, 8 \mathrm{March}$. No cementing of Hole 634A was necessary, and the mud line was cleared at $1755 \mathrm{hr}$. Because the decision had already been made to proceed to nearby BAH-3-A (Site 635) with approximately $2300 \mathrm{~m}$ of drill string in the water, the Resolution left for that location at a speed of 1.0-1.5 kt in dynamic-positioning mode with thrusters extended at $1845 \mathrm{hr}, 8 \mathrm{March}$.

The coring summary for Site 634 appears in Table 1.

\section{SEDIMENTOLOGY}

\section{Introduction}

A single hole was drilled at Site 634 with a total penetration of $479.4 \mathrm{~m}$ sub-bottom. The interval between 6.4 and $144 \mathrm{~m}$ sub-bottom was washed. The total cored section was $322.5 \mathrm{~m}$, and total recovery was $27.3 \mathrm{~m}(8.5 \%)$.

Sediments at Site 634 are divided into four major lithologic units, all of which can be correlated with those at DSDP Site 98 (Hollister et al., 1972). The upper and lower boundaries of each unit cannot always be precisely defined because of poor recov- ery and discontinuous coring. Unit I, 0-3.1 m sub-bottom, consists of calcareous ooze. Unit II, 3.1-6.4 m sub-bottom, contains calcareous ooze and chalk. Unit III, 144-182.1 m sub-bottom, consists of hard chalk with chert. Unit IV, 182.1-479.4 m sub-bottom, contains interbedded calcareous grainstones, rudstones, and chalk, with some boundstones, floatstones, and cherts. Figure 4 summarizes the lithologic units plus smear slide data.

\section{Unit I (0-3.1 m sub-bottom; Core 634A-1R-1 to Sample 634A-1R-3, $11 \mathrm{~cm}$ )}

Unit I consists of calcareous ooze, slightly laminated in places, with some burrowing. This burrowing is emphasized by gray pyrite staining and slight color differences. The color ranges from pale brown (10YR 6/3) through very pale brown (10YR 7/3) to mottled light gray (10YR 7/2) and white (2.5Y 7/2). Smear slide data (Fig. 4) indicate nannofossils to be the primary constituents, with subordinate, fine-sand-sized planktonic foraminifers, skeletal fragments, and pteropods. Rare chalky clasts (?cemented aggregates of the ooze) are present near the base of the unit. A pteropod-rich sand layer, possibly the result of winnowing, is present at $2.60 \mathrm{~m}$ sub-bottom. Needles, probably aragonite, are visible in smear slides (about 5\%) throughout the unit, and aragonite is shown to be present by $\mathrm{x}$-ray-diffraction (XRD) analyses (see "Inorganic Geochemistry" section, this chapter). These needles indicate that the unit is composed of periplatform ooze. The base of the unit is defined at the top of a chalky layer in Core 634A-1R-3, $3.10 \mathrm{~m}$ sub-bottom. Unit I has been dated as late Pleistocene ( $<80,000 \mathrm{yr})$ in age ("Biostratigraphy" section, this chapter).

Table 1. Coring summary, Site 634.

\begin{tabular}{|c|c|c|c|c|c|c|c|}
\hline $\begin{array}{c}\text { Core } \\
\text { no. }\end{array}$ & $\begin{array}{l}\text { Core } \\
\text { type }^{a}\end{array}$ & $\begin{array}{l}\text { Date } \\
\text { (Mar. } \\
1985)\end{array}$ & Time & $\begin{array}{l}\text { Sub-bottom } \\
\text { depths } \\
\text { (m) }\end{array}$ & $\begin{array}{l}\text { Length } \\
\text { cored } \\
\text { (m) }\end{array}$ & $\begin{array}{l}\text { Length } \\
\text { recovered } \\
\text { (m) }\end{array}$ & $\begin{array}{l}\text { Percentage } \\
\text { recovered }\end{array}$ \\
\hline \multicolumn{8}{|c|}{ Hole 634A } \\
\hline 1 & $\mathbf{R}$ & 4 & 0320 & $0-6.4$ & 6.4 & 6.37 & 99 \\
\hline 2 & $\mathbf{R}$ & 4 & 1130 & $144.0-153.6$ & 9.6 & 7.22 & 75 \\
\hline 3 & $\mathbf{R}$ & 4 & 1300 & $153.6-163.1$ & 9.5 & 0.40 & 4 \\
\hline 4 & $\mathbf{R}$ & 4 & 1415 & $163.1-172.4$ & 9.3 & 3.75 & 40 \\
\hline 5 & $\mathbf{R}$ & 4 & 1545 & $172.4-182.1$ & 9.7 & 0.06 & 0 \\
\hline 6 & $\mathrm{R}$ & 4 & 1715 & $182.1-191.5$ & 9.4 & 1.23 & 13 \\
\hline 7 & $\mathbf{R}$ & 4 & 1900 & $191.5-201.1$ & 9.6 & 0 & 0 \\
\hline 8 & $\mathbf{R}$ & 4 & 2015 & $201.1-210.7$ & 9.6 & 0.04 & 0 \\
\hline 9 & $\mathbf{R}$ & 4 & 2137 & $210.7-220.3$ & 9.6 & 0 & 0 \\
\hline 10 & $\mathbf{R}$ & 4 & 2315 & $220.3-229.9$ & 9.6 & 0.18 & 1 \\
\hline 11 & $\mathbf{R}$ & 5 & 0105 & $229.9-239.6$ & 9.7 & 0.79 & 8 \\
\hline 12 & $\mathbf{R}$ & 5 & 0255 & $239.6-248.6$ & 9.0 & 0.02 & 0 \\
\hline 13 & $\mathbf{R}$ & 5 & 0515 & $248.6-258.2$ & 9.6 & 0.86 & 8 \\
\hline 14 & $\mathbf{R}$ & 5 & 0730 & $258.2-267.8$ & 9.6 & 0.25 & 2 \\
\hline 15 & $\mathbf{R}$ & 5 & 0915 & $267.8-277.4$ & 9.6 & 0.04 & 0 \\
\hline 16 & $\mathbf{R}$ & 5 & 1200 & $277.4-287.1$ & 9.7 & 0.15 & 1 \\
\hline 17 & $\mathbf{R}$ & 5 & 1415 & $287.1-296.8$ & 9.7 & 0.07 & 0 \\
\hline 18 & $\mathbf{R}$ & 5 & 1600 & $296.8-306.4$ & 9.6 & 0.06 & 0 \\
\hline 19 & $\mathbf{R}$ & 5 & 1800 & $306.4-316.0$ & 9.6 & 0.05 & 0 \\
\hline 20 & $\mathbf{R}$ & 5 & 1950 & $316.0-325.6$ & 9.6 & 0 & 0 \\
\hline 21 & $\mathbf{R}$ & 5 & 2200 & $325.6-335.3$ & 9.7 & 0 & 0 \\
\hline 22 & $\mathbf{R}$ & 6 & 0340 & $354.6-364.2$ & 9.6 & 0.65 & 6 \\
\hline 23 & $\mathbf{R}$ & 6 & 0530 & $364.2-373.8$ & 9.6 & 0.09 & 0 \\
\hline 24 & $\mathbf{R}$ & 6 & 0740 & $373.8-383.3$ & 9.5 & 0.04 & 0 \\
\hline 25 & $\mathbf{R}$ & 6 & 0945 & $383.3-392.9$ & 9.6 & 0.55 & 5 \\
\hline 26 & $\mathbf{R}$ & 6 & 1145 & $392.9-402.5$ & 9.6 & 0.07 & 0 \\
\hline 27 & $\mathbf{R}$ & 6 & 1400 & $402.5-421.8$ & 19.3 & 0.28 & 1 \\
\hline 28 & $\mathbf{R}$ & 6 & 1615 & $421.8-441.1$ & 19.3 & 2.05 & 10 \\
\hline 29 & $\mathbf{R}$ & 6 & 1815 & $441.1-450.7$ & 9.6 & 0.71 & 7 \\
\hline 30 & $\mathbf{R}$ & 6 & 2045 & $450.7-460.3$ & 9.6 & 0.43 & 4 \\
\hline 31 & $\mathbf{R}$ & 7 & 0130 & $460.3-469.9$ & 9.6 & 0.56 & 5 \\
\hline 32 & $\mathbf{R}$ & 7 & 1010 & $469.9-479.4$ & 9.5 & 0.06 & 0 \\
\hline
\end{tabular}

${ }^{\mathrm{a}} \mathrm{R}=$ rotary. 


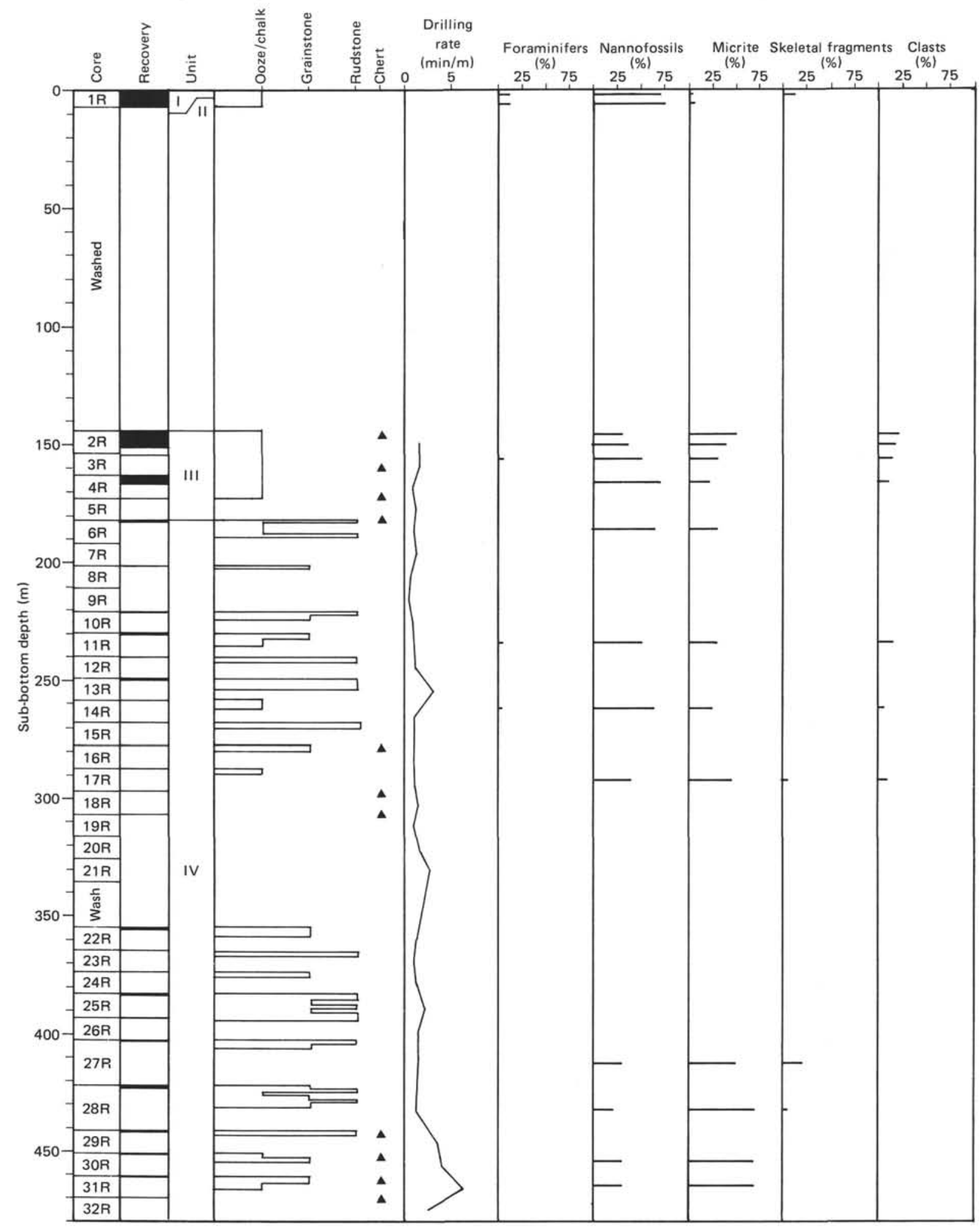

Figure 4. Summary of lithologic and smear slide data, Site 634.

Unit II (3.1-6.4 m sub-bottom; Sample 634A-1R-3, 11 $\mathrm{cm}$, to base of Core 634A-1R)

The top of Unit II is marked by a chalk layer at Sample 634A-1R-3, $11 \mathrm{~cm}$, which corresponds to a biostratigraphic break between the lower Pliocene and upper Pleistocene (see "Biostra- tigraphy" section, this chapter). This break is coincident with a pronounced color change from predominantly pale browns (see above) to white $(2.5 \mathrm{Y} 8 / 2)$ plus a change from ooze to ooze plus friable chalk layers. In Sections 634A-1R-3 and 634A-1R-5, chalks total approximately $70 \%$; Sections 634A-1R-4 and 634A$1 \mathrm{R}$, CC contain only calcareous ooze. Unit II is slightly bur- 
rowed and contains abundant (up to 5\%) flecks of (probable) limonite. The composition of the sediment is similar to that in Unit I, predominantly nannofossils with subordinate planktonic foraminifers (Fig. 4). No pteropods are present. Although needles $(3 \%)$, apparently of aragonite, are visible in smear slides, $\mathrm{XRD}$ analyses indicate an absence of aragonite (see "Inorganic Geochemistry" section, this chapter). Unit II is interpreted as being periplatform ooze of early Pliocene age (see "Biostratigraphy" section, this chapter). The base of Unit II is marked at the bottom of Core $634 \mathrm{~A}-1 \mathrm{R}$, although patchy coring below this depth at DSDP Site 98 indicates that this unit may continue through to the lower-middle Eocene at about $110 \mathrm{~m}$ sub-bottom.

\section{Unit III (144-182.1 m sub-bottom; Core 634A-2R to base of Core $634 \mathrm{~A}-4 \mathrm{R}$ )}

No cores were taken between 6.4 and $144 \mathrm{~m}$ sub-bottom. The top of Unit III is placed at the top of Core 634A-2R (144 m subbottom). Unit III consists of chalk and hard chalk (white, $2.5 \mathrm{Y}$ $8 / 2,10$ YR $8 / 2$, and 10YR 8/1) with chert at Samples 634A-2R-1, 25-30 cm, 634A-2R-1, 125-150 cm (Fig. 6), 634A-2R-2, 71-72 $\mathrm{cm}, 634 \mathrm{~A}-2 \mathrm{R}-3,124-126 \mathrm{~cm}$ and $134-136 \mathrm{~cm}, 634 \mathrm{~A}-2 \mathrm{R}-4,53-57$ $\mathrm{cm}$, and $634 \mathrm{~A}-3 \mathrm{R}, \mathrm{CC}$. The chert has irregular boundaries in many places (Fig. 5), is pale yellow (5Y 7/3), and is very fine grained with few or no carbonate inclusions.

Unit III displays moderate burrowing, along with indistinct layering, at many places (Fig. 6). Zoophycos-type feeding traces obliquely crosscut the sediments (Sample 634A-4R-1, 50-60 cm). Some inclined layers are present, at $12^{\circ}$ from the horizontal $(634 \mathrm{~A}-2 \mathrm{R}-1,75-80 \mathrm{~cm})$ and at approximately $7^{\circ}(634 \mathrm{~A}-2 \mathrm{R}-5$, $85-102 \mathrm{~cm}$, and $634 \mathrm{~A}-4 \mathrm{R}-3)$. These inclined layers could indicate either low-angle slumping or, perhaps more likely, the depositional slope.

Micrite and nannofossils are the dominant components of Unit III sediments (Fig. 4). The relative percentage of micrite decreases with depth in this unit, whereas that of nannofossils increases. This could be a depositional trend, or it may be the result of diagenesis. Lithified clasts are also a major component; foraminifers are rare. Traces of volcanic glass were noted in Samples 634A-2R-4, $75 \mathrm{~cm}$, and 634A-3R-1, $30 \mathrm{~cm}$. No aragonite needles were observed, and XRD analyses show no aragonite to be present (see "Inorganic Geochemistry" section, this chapter). Round specks of pyrite, in discontinuous laminae in places, occur in Core 634A-2R and in Core 634-4R, where limonitic specks are also present. In spite of the lack of identifiable aragonite, this unit is considered to have been originally deposited as periplatform ooze.

Recovery was variable: $75 \%$ in Core $634 \mathrm{~A}-2 \mathrm{R}, 4 \%$ in Core $634 \mathrm{~A}-3 \mathrm{R}$, and $40 \%$ in Core $634 \mathrm{~A}-4 \mathrm{R}$. Core $634 \mathrm{~A}-5 \mathrm{R}$ contained only a single piece of chert, which may have fallen from higher in Unit III. The age of the sediments in Unit III is latest Paleocene to early Eocene (see "Biostratigraphy" section, this chapter).

\section{Unit IV (182.1-479.4 m sub-bottom; Core 634A-6R to Core 634A-32R)}

Unit IV commences at the top of Core $634 \mathrm{~A}-6 \mathrm{R}$ with the first occurrence of coarse-grained sediments. It is possible that an early Eocene-latest Paleocene to late Campanian unconformity is present within the interval of Core 634A-5R (172.4-182 m sub-bottom) (see "Biostratigraphy" section, this chapter).

Recovery in Unit IV was generally poor, varying between $0 \%$ and $13 \%$ (Core 634A-6R), with 14 (out of a total of 27) cores giving zero to trace recovery. Core $634 \mathrm{~A}-6 \mathrm{R}$ consists predominantly of hard white chalk (10YR $8 / 1$ and whiter); little chalk was recovered in the remainder of this unit. At DSDP Site 98, however, chalk was recovered throughout the Campanian (Fig. 6;

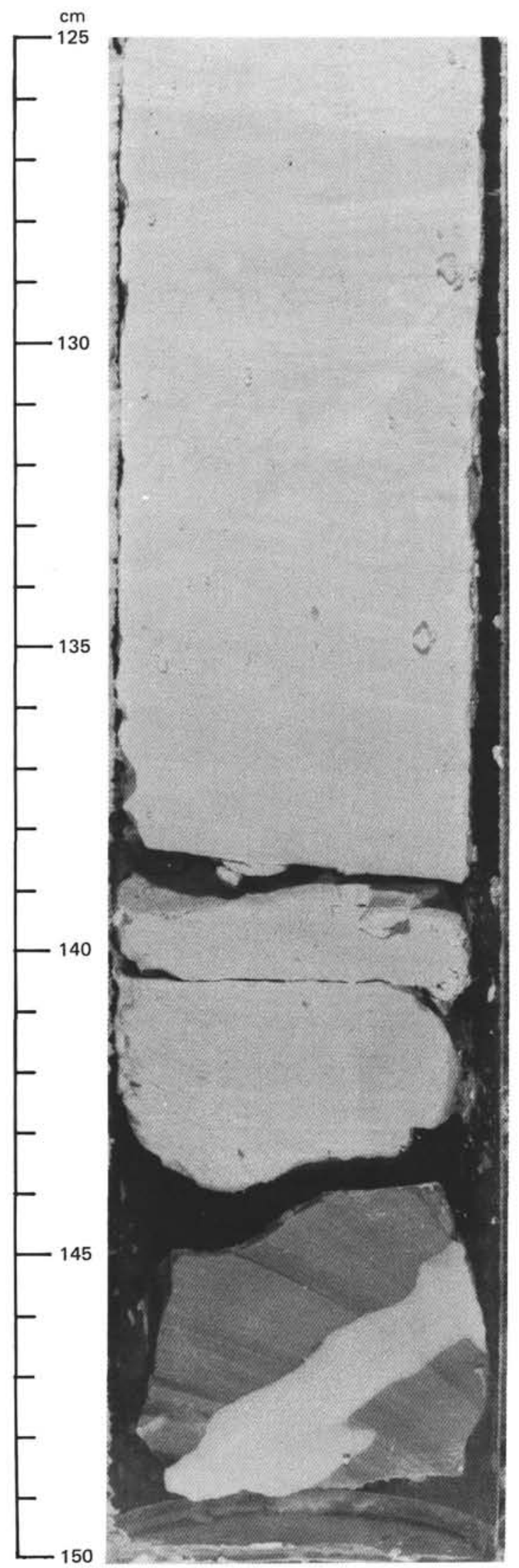

Figure 5. Burrowed and laminated chalk overlying chert in Unit III, Sample $643 \mathrm{~A}-2 \mathrm{R}-1,125-150 \mathrm{~cm}$. Chert only partly replaces chalk. 


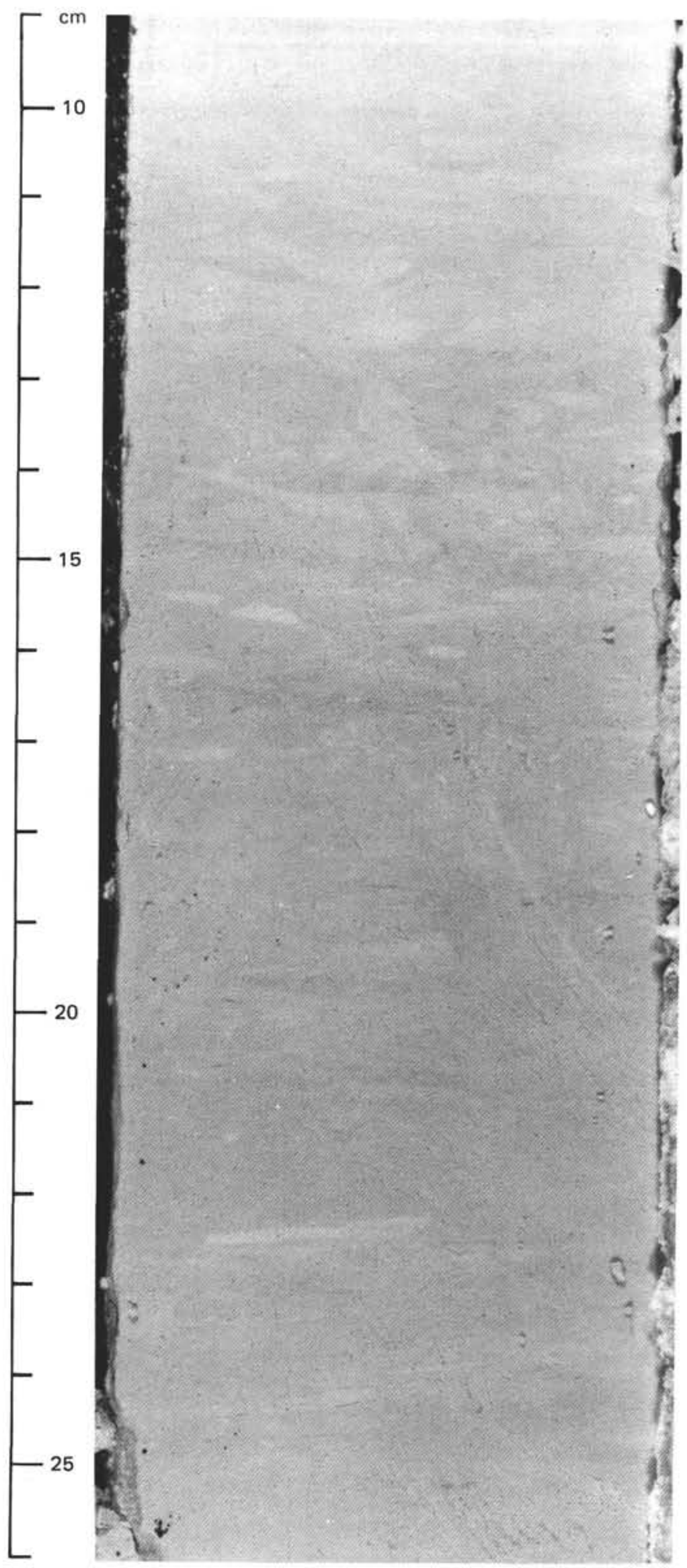

Figure 6. Burrows and laminations in chalk, Unit III, Sample 634A-2R$4,9-26 \mathrm{~cm}$. Some parallel, inclined burrows visible at $22-25 \mathrm{~cm}$.

Hollister et al., 1972). The presence of both chalk and possible minor ooze is inferred by correlation with DSDP Site 98 , by the recovery of small amounts of chalk (Fig. 4), and by the overall poor recovery. The chalk may have been ground up and washed out, with only the harder grainstones and rudstones remaining within the core barrel. Chalk was recovered in Samples 634A-
$11 \mathrm{R}-1,30-57 \mathrm{~cm}$ (with ooze at 57-65 cm), 634A-14R-1 and CC, 634A-17R, CC, 634A-28R-2, 8-14 cm, 634A-30R-1, 0-15 cm, and $634 \mathrm{~A}-31 \mathrm{R}-1,52-58 \mathrm{~cm}$.

The chalk consists primarily of nannofossils and micrite. The percentage of obvious nannofossils in smear slides decreases with depth, whereas the micrite content increases. Limonite flecks are present in many places, and limonitic laminations occur in Sample 634A-30R-1, 13-14 cm (Fig. 7). Pyrite occurs in chalk in Section 634A-17R, CC. Obvious burrowing is not commonly visible, but a single burrow filled with coarser sediment (packstone) occurs in Sample 634A-14R-1, 6-7 cm.

The coarse-grained sediments consist primarily of lithified grainstones and rudstones, with rare boundstones and floatstones. They are composed of skeletal debris and lithified lime-

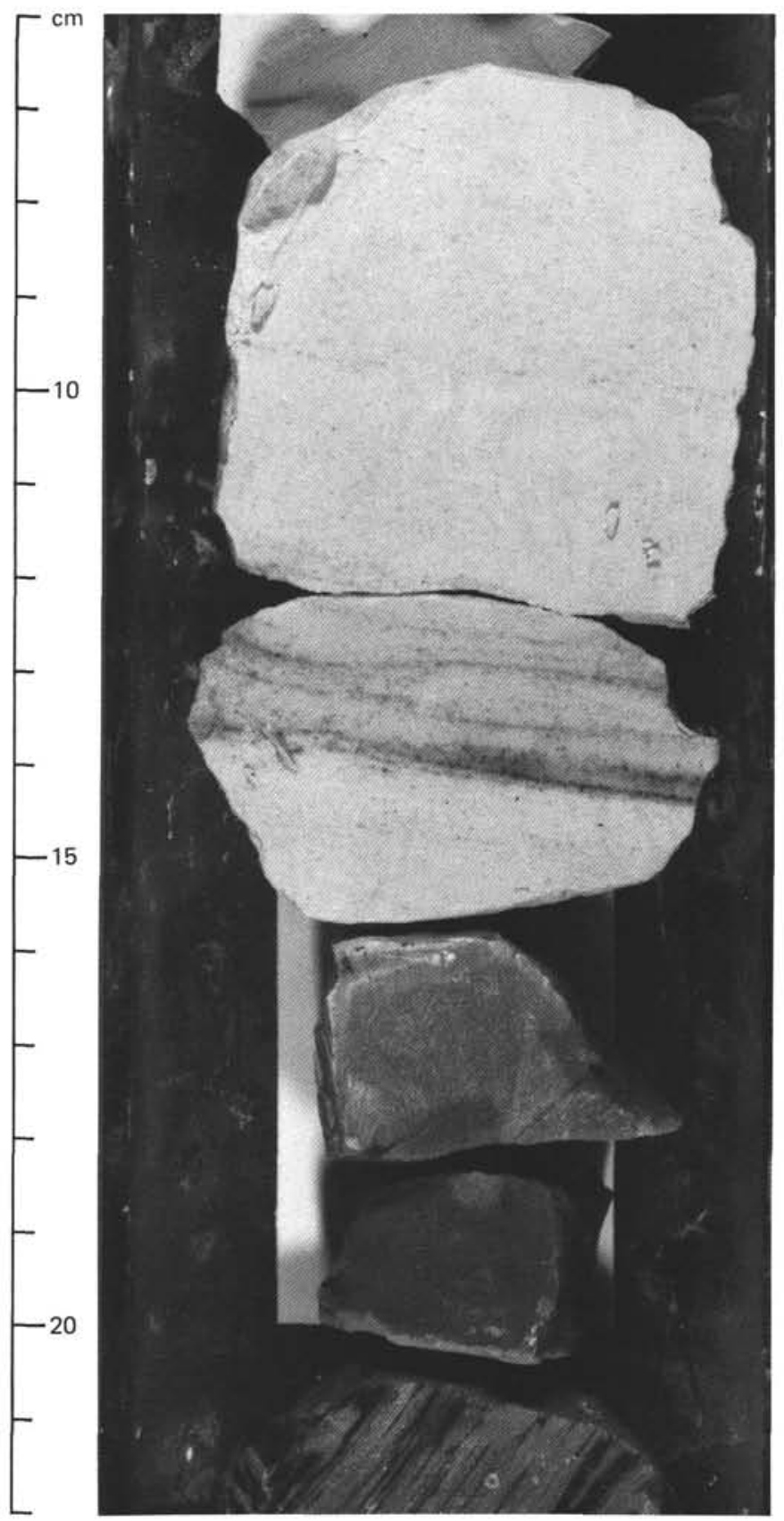

Figure 7. Chalk overlying chert in Unit IV, Sample 634A-30R-1, 6-22 $\mathrm{cm}$. Prominent limonitic laminations are present in chalk at $13-14 \mathrm{~cm}$. 
stone clasts and, in places, chalk clasts. Their predominant color is white (10YR $8 / 1$, with some $10 \mathrm{YR} 8 / 2$ and $2.5 \mathrm{Y} 8 / 2$ ). These coarse-grained sediments can be divided into two types: type A, sediments that were obviously lithified in situ; and type $\mathrm{B}$, sediments that were possibly lithified on an adjacent carbonate platform and were transported downslope as cobbles or boulders.

Type A sediments are commonly friable, although some are well cemented. Color is commonly white (10YR $8 / 1,10 \mathrm{YR} 8 / 2$, or $2.5 \mathrm{Y} 8 / 2$ ). The sediments range from clean, well-sorted, medium-sand-sized grainstones (Sample 634A-22R-1, 0-60 cm) to poorly sorted, friable, coarse grainstones and rudstones with angular to subrounded clasts (Fig. 8). The former contain subrounded to rounded skeletal grains plus foraminifers, whereas the latter contain chalk, lithoclasts, and skeletal grains. Rudist fragments are common within these sediments and commonly average $0.5-0.8 \mathrm{~cm}$ in diameter. Platy grains are oriented subparallel to the horizontal (Fig. 8). Grain size ranges from medium sand through granules to coarse pebbles. Within the lower part of Unit IV (Cores 634A-28R and 634A-32R), poorly sorted, friable grainstones and rudstones contain numerous chalk clasts

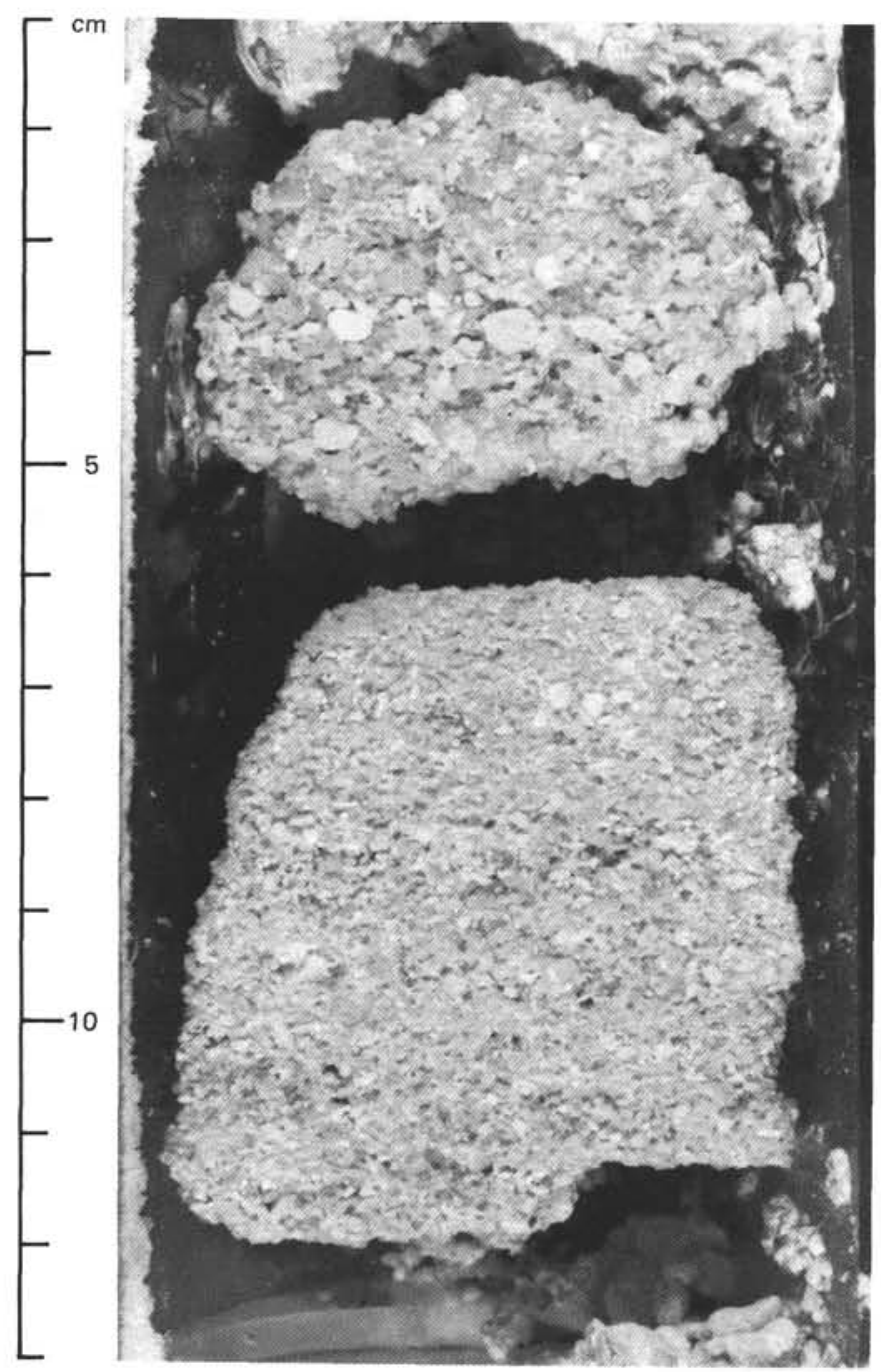

Figure 8. Type A, lithified in situ, coarse grainstones and rudstones in Unit IV, Sample 634A-6R, CC, 1-13 cm. Some subhorizontal orientation of platy fragments is apparent. with, in addition, common spots and streaks of probable limonite, giving the sediments a yellowish hue (2.5Y 8/2). A single clast of limonite-stained ooze is also present (Fig. 9). Small $(<0.6 \mathrm{~cm})$ clasts of chert are also present in some of these sediments. These type A grainstones and rudstones are interpreted to be derived jointly from an adjacent shallow-water-carbonate platform (most skeletal grains) and from slope sediments (chalk and chert clasts). They were redeposited as sands and gravels in sediment gravity-flow deposits at the toe of the depositional slope or along the basin margins.

The type B sediments comprise white (mostly 10YR $8 / 2$ ), well-cemented grainstones and rudstones with rare boundstones and floatstones. Skeletal clasts include rudists, echinoids, gastropods, hydrozoans, bivalves, corals, peloids, and encrusting and larger foraminifers; rudists are the most common skeletal clasts and may be greater than $2 \mathrm{~cm}$ across. Grains are rounded to angular, the shape being dependent on skeletal origin. Many skeletal fragments have micritized borders. Two large rudist fragments were present (Fig. 10; Samples 634A-10R, CC and 634A$27 \mathrm{~W}-1,5-9 \mathrm{~cm})$. This assemblage characterizes shallow-water platform-margin carbonates during the Campanian. The skeletal grains are commonly tightly cemented together and are present in cobbles up to $7 \mathrm{~cm}$ in diameter. We interpret these limestone fragments to be platform-derived clasts that were washed out, during drilling, from layers of rubble with a chalk or foraminiferal-sand matrix. Remnants of a chalk matrix were present on the clasts in some places; unlithified foraminiferal sands were recovered at DSDP Site 98 (see discussion). Other pieces of similar lithology have well-developed moldic porosities with little or no chalk fill (Figs. 11 and 12), although a partial late spar fill is present.

The grains within type B grainstones and rudstones are derived from the adjacent carbonate platform. They may have been reworked as gravity deposits before cementation on the platform, with later cementation on the basin floor. However, the contrast in cementation between these sediments and the more friable type A grainstones and rudstones suggests that type B sediments were cemented on the platform from whence they were derived in the form of boulders and cobbles. Shore-based diagenesis studies will aid evaluation of their origin.

One piece of fine-grained chert (a possible result of downhole collapse) is present near the top of Core 634A-6R. There is

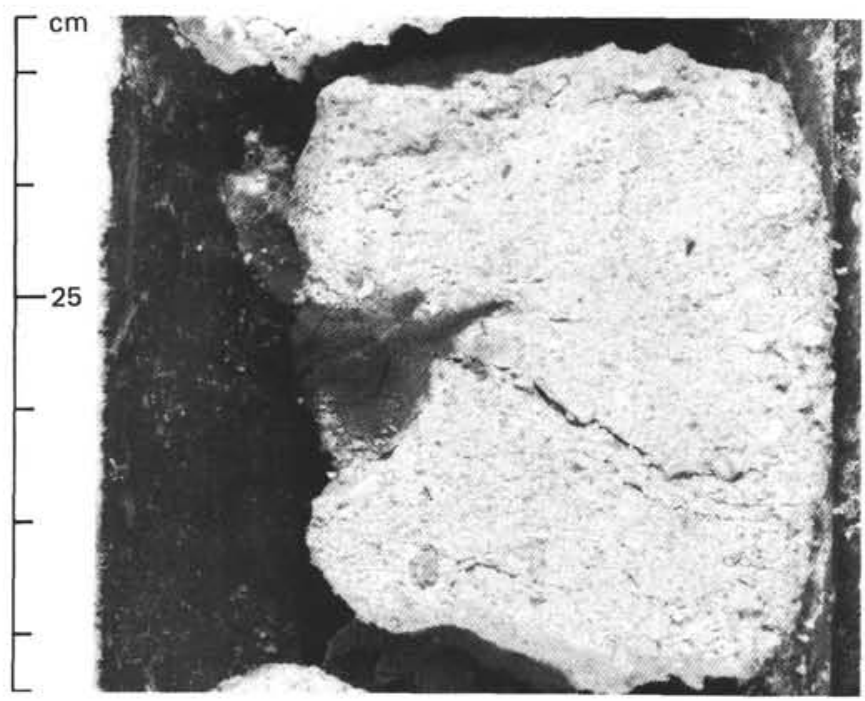

Figure 9. Soft clast of limonite(?) in grainstone, Sample 634A-28R-1, $25-26 \mathrm{~cm}$. Grainstone has a high percentage $(>40 \%)$ of chalk clasts. 


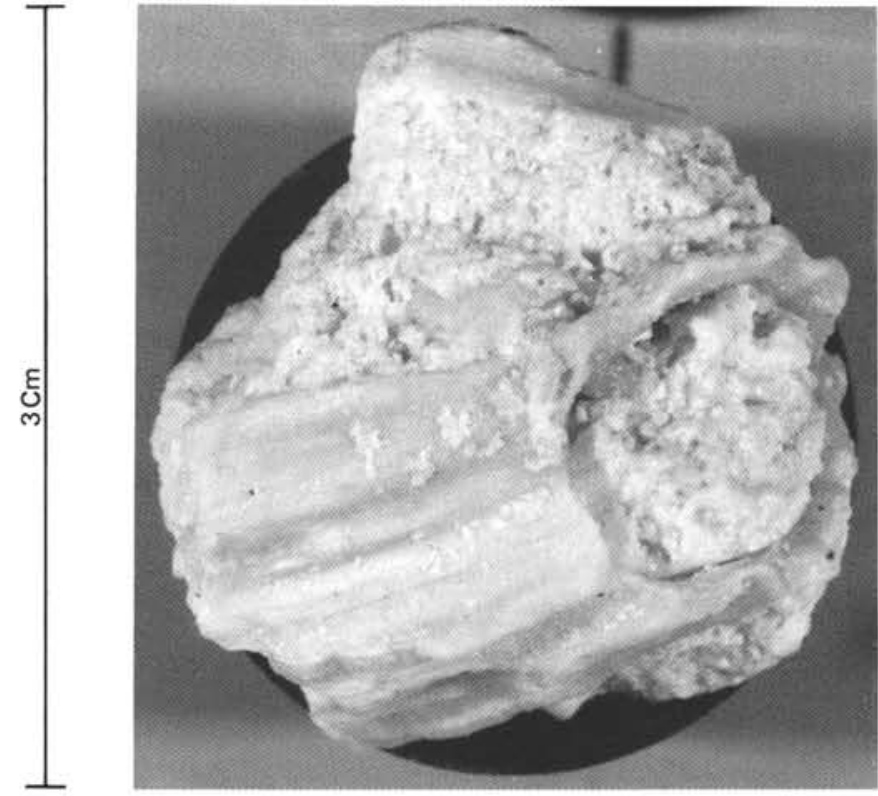

Figure 10. Almost-complete rudist valve, Section 634A-10R, CC; diameter of rudist is $3 \mathrm{~cm}$.

little further chert until Section 634A-16R, CC (278.0 m subbottom), where coarser grained cherts are present. Chert constitutes the only recovery in Cores 634A-18R and 634A-19R, but then it is not recovered until Samples $634 \mathrm{~A}-29 \mathrm{R}-1,51-53 \mathrm{~cm}$, and 634A-29R, CC (441.6-441.8 m sub-bottom) and is then present to the base of Hole 634A. Chert is particularly abundant in Samples 634A-30R-1, 15-34 cm, and 634A-31R-1, 25-48 cm. Colors are white $(7.5 \mathrm{YR} 8 / 0,10 \mathrm{YR} 7 / 1)$, light gray $(2.5 \mathrm{Y} 6 / 1$, 5Y 5/1, 7.5YR 5/0, 7.5YR 6/1, and 10YR 6/1), gray, and dark grayish brown (2.5Y 4/2).

Ghosts of former carbonate grains, particularly rudist clasts, are visible within these cherts (Figs. 13 and 14). The grains have a similar size range to those in adjacent grainstones and rudstones. Some laminated cherts are also present (Samples 634A$31 \mathrm{R}-1,24-25 \mathrm{~cm}$, and 634A-32R, CC). Other cherts contain clasts of a previous generation of chert, similar to the chert clasts present in type A grainstones and rudstones. Silicification occurs preferentially in certain grains and cements in these sediments. Unit IV cherts are distinct from the compact, fine-grained cherts of Unit III and can be readily distinguished from these. Their evolution will form a further shore-based study.

\section{Summary}

Unit I: 0-3.1 m sub-bottom; Sections 634A-1R-1 to $634 \mathrm{~A}-1 \mathrm{R}-3,11 \mathrm{~cm}$, upper Pleistocene calcareous ooze.

Unit II: 3.1-6.4 m sub-bottom; Sample $634 \mathrm{~A}-1 \mathrm{R}-3,11 \mathrm{~cm}$, to base of Core 634A-1R, lower Pliocene calcareous ooze and friable chalk.

6.4-144 m sub-bottom: washed.

Unit III: $144-182.1 \mathrm{~m}$ sub-bottom; Core 634A-2R to base of Core 634A-5R, lower Eocene hard chalk with chert.

Unit IV: $182.1-479.4 \mathrm{~m}$ sub-bottom; Core $634 \mathrm{~A}-6 \mathrm{R}$ to $634 \mathrm{~A}-32 \mathrm{R}$, interbedded calcareous grainstones, rudstones, and chalk of early to late Campanian age, with varying amounts of chert.

\section{Discussion}

The depositional environments of Units I, II, and III are similar. All three units are composed of periplatform ooze with varying degrees of lithification. The older unit, Unit III, is entirely chalk at Site 634 . These sediments are characteristic of bypass slopes, which exhibit high relief between platform and ba-
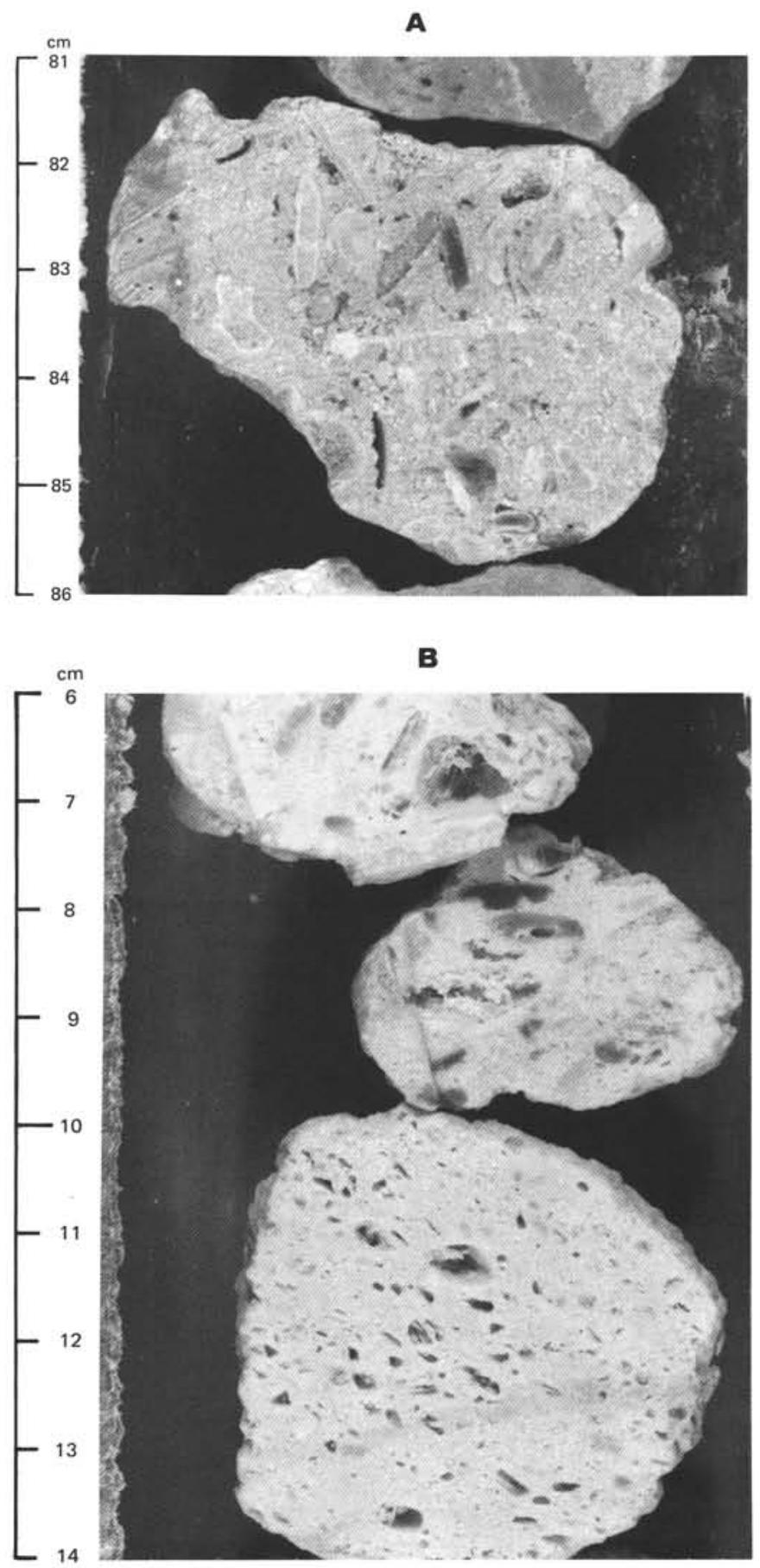

Figure 11. Type B grainstones, Unit IV. A. Cemented grainstone-rudstone with some remaining primary porosity, Sample 634A-28R-1, 81$86 \mathrm{~cm}$. B. Cemented grainstone cobbles with well-developed moldic porosity. Later calcite spar is present in some molds. Sample 634A-10R, CC, $6-14 \mathrm{~cm}$.

sin (although they also can be found on accretionary and eroded slopes). Some $4500 \mathrm{~m}$ of relief characterizes the Northeast Providence Channel system today.

Gravity deposits were absent from Units I, II, and III. In contrast, Unit IV contains many gravity-flow deposits interbedded with chalks. Clasts in the sediment gravity flows were derived from both slope and platform, indicating deposition on a flat basin floor near the base of the slope, as proposed by Schla- 


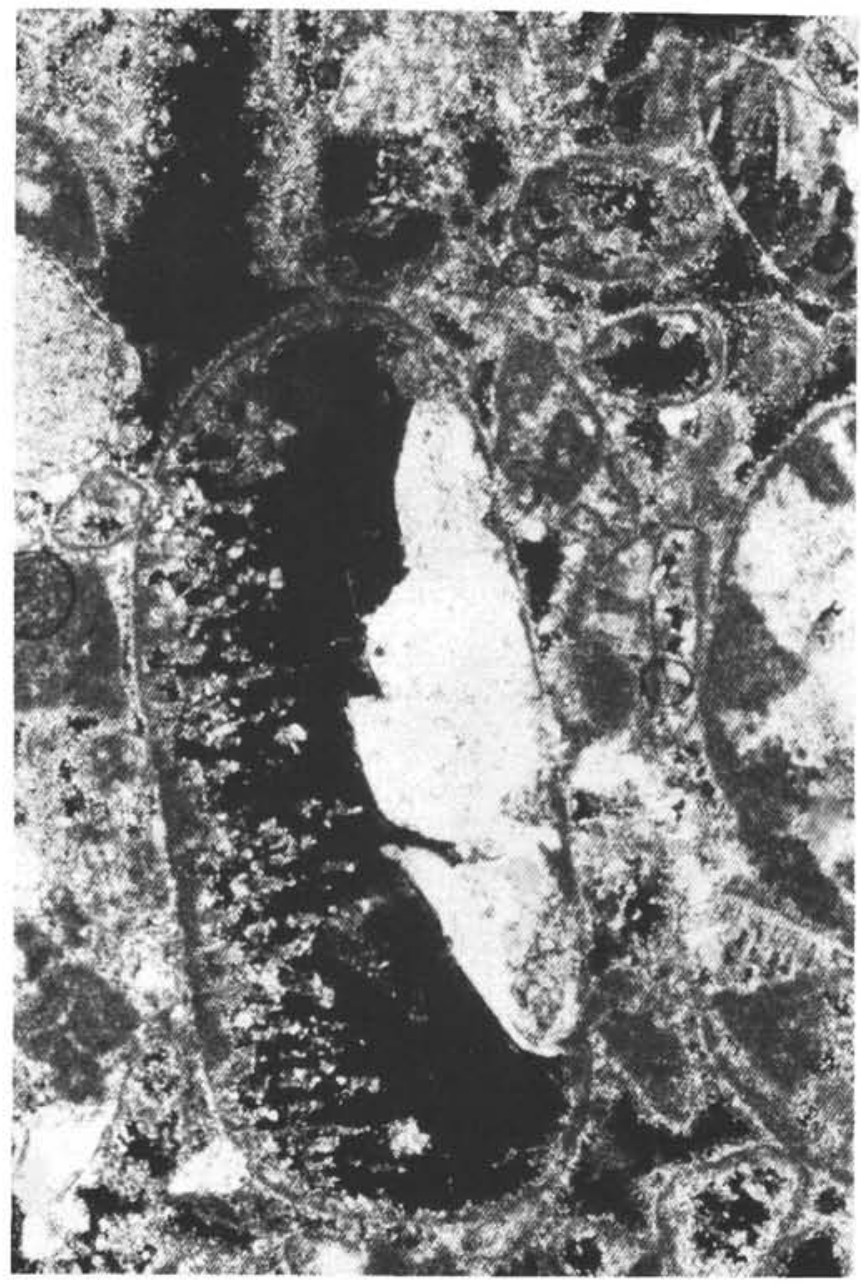

Figure 12. Thin-section photomicrograph of moldic porosity with later spar fill, Section 634A-8R, CC. Crossed nicols; long dimension of photomicrograph is $32 \mathrm{~mm}$.

ger and Ginsburg (1981) for the coeval deposits in DSDP Site 98. Evidence indicates that the relief between platform and basin was much less during the Campanian than at present, with estimates of relief varying between $300 \mathrm{~m}$ (Paulus, 1972) and $1500 \mathrm{~m}$ (Freeman-Lynde et al., 1981).

The type B clasts in Unit IV are similar to those at the foot of the Campeche Escarpment reported by Halley et al. (1984). They interpreted the moldic porosity to have formed in deep water by selective leaching of aragonite. They discounted a shallow-water origin because of the absence of chalk within the moldic porosity. The presence of many cemented grainstones and rudstones without moldic porosities can be considered evidence against deep-water development of moldic porosity in situ. Porosity evolution and the diagenesis of these sediments will form part of a shore-based study.

Recovery throughout Unit IV was poor (3.4\%); thus the exact proportions of the different sediments which make up the unit are not known. However, wireline logs run through this section allow estimation of these proportions (see "Seismic Stratigraphy" section, this chapter). The interdigitation of chalks with coarse, platform-derived sediments indicates a constant background sedimentation with sporadic incursions of gravity deposits. These vary from well-sorted medium sands through poorly sorted rudstones to cobbles and boulders and are interpreted as turbidites and debris flows. Unit IV has been dated as early

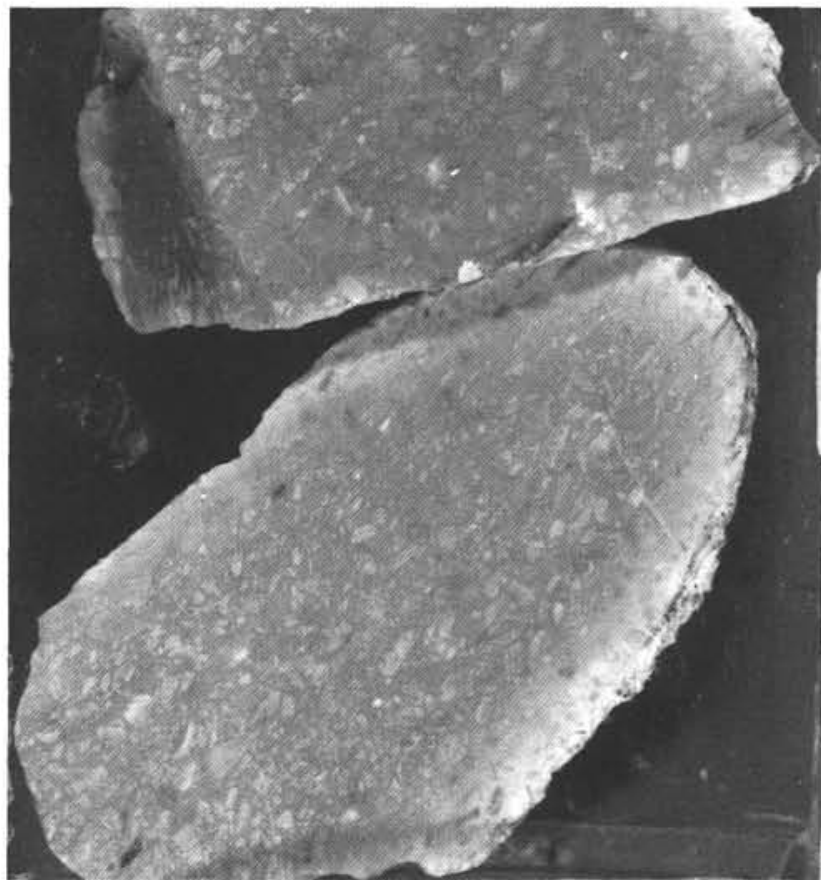

Figure 13. Chert in Unit IV, showing ghosts of former carbonate grains, Section 634A-16R, CC.

Campanian at the base to late Campanian at the top with a constant average accumulation rate (see "Biostratigraphy" section, this chapter).

\section{Comparison with DSDP Site 98}

A comparison between the lithologic units present at both sites is shown in Figure 15. Although coring was not continuous at either site, there is a good lithologic and biostratigraphic correlation at the top of the Campanian. Site 98 (Hollister et al., 1972) only penetrated $354 \mathrm{~m}$ of sediment; Site 634 continued to $479.4 \mathrm{~m}$ but encountered no new lithologic units (Fig. 15).

At DSDP Site 98, Campanian oozes and unlithified foraminiferal sands were recovered, whereas all sediment of this age recovered at Site 634 was lithified. In addition, chalk and ooze formed most of the Campanian sediment recovered at Site 98, with lithified rudstone subordinate. This supports the assertion that chalk and foraminiferal sands are present at Site 634 but were not recovered, having been largely washed out. Furthermore, lower Eocene ooze was recovered at Site 98 compared to chalk alone at Site 634. We are not certain if this is the result of slight differences in diagenesis between the two sites or if these discrepancies can be explained by changes in drilling techniques.

\section{BIOSTRATIGRAPHY}

\section{Introduction}

Drilling at Site 634 recovered an incomplete section from Campanian to Quaternary containing ooze, chalk, chert, and limestone with a total penetration to $479 \mathrm{~m}$ sub-bottom. The Cenozoic section contains pelagic ooze, periplatform ooze, chalks, and cherts bearing abundant to common planktonic microfossils. The Campanian section includes pelagic chalk interbedded with chert and limestone turbidites derived from the nearby platform. Much of this platform material is barren of planktonic microfossils. Fortunately, enough interbedded chalk was recovered to allow biostratigraphic assignment of the Campanian sequence.

All samples are from core catchers unless otherwise specified. 


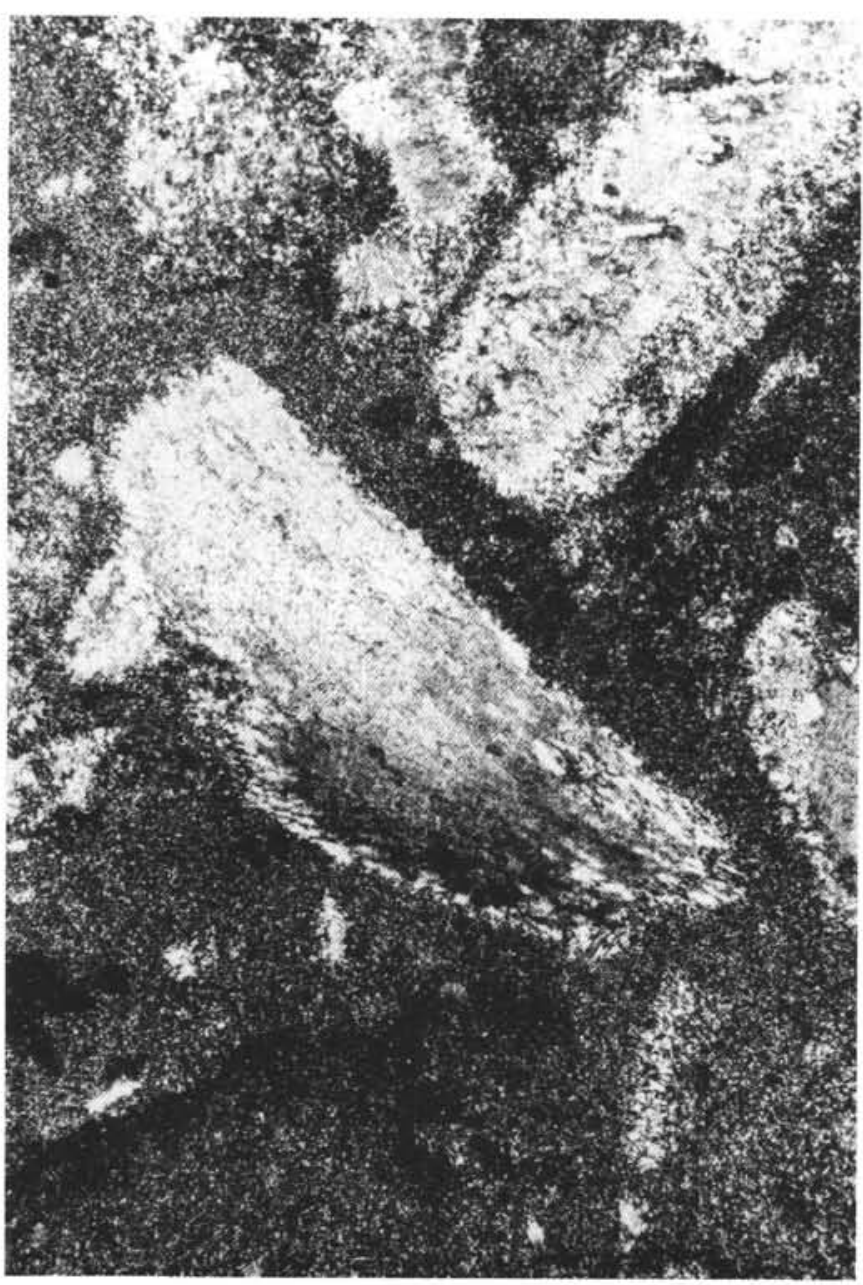

Figure 14. Thin-section photomicrograph of upper chert shown in Figure 13, showing carbonate grain in matrix of chert, Section 634A-16R, CC. Crossed nicols; long dimension of photomicrograph is $32 \mathrm{~mm}$.

\section{Calcareous Nannofossils}

The top of the mud-line core (Core $634 \mathrm{~A}-1 \mathrm{H}, 1 \mathrm{~cm}$ ) contains abundant Emiliania huxleyi, indicating the Emiliania huxleyi Acme Zone of Gartner (1977). This zone correlates with the latest Pleistocene and Holocene. At the base of this core (Sample 634A-1H, CC), the co-occurrence of Amaurolithus primus, Amaurolithus delicatus, Amaurolithus amplificus, and Discoaster asymmetricus indicates Zone NN12, which correlates with part of the early Pliocene. Following the recovery of the mudline core, the hole was washed down to $144 \mathrm{~m}$ sub-bottom.

Section 634A-2H, CC contains an abundant, moderately preserved assemblage that includes Discoaster multiradiatus, Discoaster barbadiensis, Tribrachiatus contortus, and Tribrachiatus orthostylus. This assemblage is assigned to Zone NP10, which correlates with the earliest Eocene. A similar assemblage occurs in Cores $634 \mathrm{~A}-3 \mathrm{H}$ through $634 \mathrm{~A}-4 \mathrm{H}$, although $T$. orthostylus is absent. This indicates the older part of Zone NP10. In Core $634 \mathrm{~A}-5 \mathrm{H}$, only chert was recovered, which could not be assigned an age based on nannofossils.

Core recovery was very poor $(2.6 \%)$ in the interval from Core 634A-6H (191.5 m sub-bottom) through 634A-31R (469.9 m subbottom). There was no recovery for some cored intervals, and only pieces of hard limestone and/or chert (barren of nannofossils) in others. Therefore, only samples from this interval that contain nannofossil assemblages are discussed.
Sample 634A-6R-1, $23 \mathrm{~cm}$, contains an assemblage with common Arkhangelskiella cymbiformis, Broinsonia parca, Quadrum trifidum, Quadrum nitidum, Broinsonia signata, Tranolithus orionatus, and Reinharditites levis. This assemblage is assigned to the older part of the Tranolithus phacelosus Zone, which correlates with the latest Campanian. This same latest Campanian assemblage continues down through Section 634A6R, CC.

Section 634A-7R, CC contains a similar assemblage with the addition of Reinhardtites anthophorus and Eiffellithus eximius, indicating the Quadrum trifidum Zone. This zone correlates with the late Campanian. Samples from Cores 634A-11R and 634A-14R contain Lithastrinus grilli, Ceratolithoides aculeus, and Quadrum nitidum without Quadrum trifidum, indicating the $Q$. nitidum Zone of early late Campanian age. Core 634A17R contains an assemblage with Ceratolithoides aculeus, Reinhardtites anthophorus, and Broinsonia parca without Quadrum nitidum, indicating the $C$. aculeus Zone. This zone correlates with the late early Campanian.

The presence of Broinsonia parca and the absence of Marthasterites furcatus and Ceratolithoides aculeus in samples from Cores $634 \mathrm{~A}-22 \mathrm{R}$ and $634 \mathrm{~A}-23 \mathrm{R}$ indicate the Calculites ovalis Zone, which correlates with the early Campanian. Section 634A$27 \mathrm{R}, \mathrm{CC}$ contains a nannofossil assemblage that is not age diagnostic.

Samples 634A-28R-1, $129 \mathrm{~cm}$, and 634A-28R, CC contain assemblages that include specimens assigned to Marthasterites sp. cf. $M$. furcatus. The occurrence of this taxon with rather primitive specimens of Broinsonia parca suggests zonal assignment to the $B$. parca Zone of the earliest Campanian. This assignment must be considered tentative, however, as no specimens of $M$. furcatus have been observed in assemblages from Core 634A-30R or Core 634A-31R. Sample 634A-28R-1, $129 \mathrm{~cm}$, is assigned to the same zone as Section 634A-28R, CC, although some notable differences in the assemblages from these two samples exist. Sample 634A-28R-1, $129 \mathrm{~cm}$, is from the matrix of a rudstone, whereas Section 634A-28R, CC is from pelagic chalk. The assemblage from the rudstone has a lower diversity than that from the pelagic chalk. In addition, the rudstone assemblage contains common Nannoconus truitti, which is unusual in a pelagic assemblage of this age. The lower diversity and abundance of nannoconids suggests that the rudstone matrix was originally deposited in shallower water relative to the in-situ pelagic material.

Cores 634A-30R and 634A-31R contain common, moderately preserved assemblages that include specimens of primitive Broinsonia parca, suggesting assignment to the $B$. parca Zone of earliest Campanian age. The absence of $M$. furcatus, however, suggests the younger $C$. ovalis Zone. As a result, these cores are tentatively assigned to the combined $B$. parca/C. ovalis zones, which correlate with the early Campanian. The basal core of the hole (Core 634A-32R) consists of chert, which cannot be dated with nannofossils.

\section{Planktonic Foraminifers}

Late Pleistocene planktonic foraminifers of the Globorotalia truncatulinoides Zone (N23) are present in Core 634A-1R, Sections 1 and 2. Early Pliocene foraminifers of the Globorotalia margaritae Zone $(\mathrm{N} 18 / \mathrm{N} 19)$ are present in the lower half of Core 634A-1R.

Cores $634 \mathrm{~A}-2 \mathrm{R}$ and $634 \mathrm{~A}-3 \mathrm{R}$ (144.0-163.1 m sub-bottom) are earliest Eocene in age, Morozovella subbotinae Zone (P6b). Diagnostic taxa include Morozovella subbotinae, $M$. formosa gracilis, and Acarinina wilcoxensis. Core $634 \mathrm{~A}-4 \mathrm{R}$ (172.4 m subbottom) is latest Paleocene in age, Morozovella velascoensis Zone (P5/P6a), as indicated by the occurrence of Morozovella velascoensis and $M$. occlusa. 

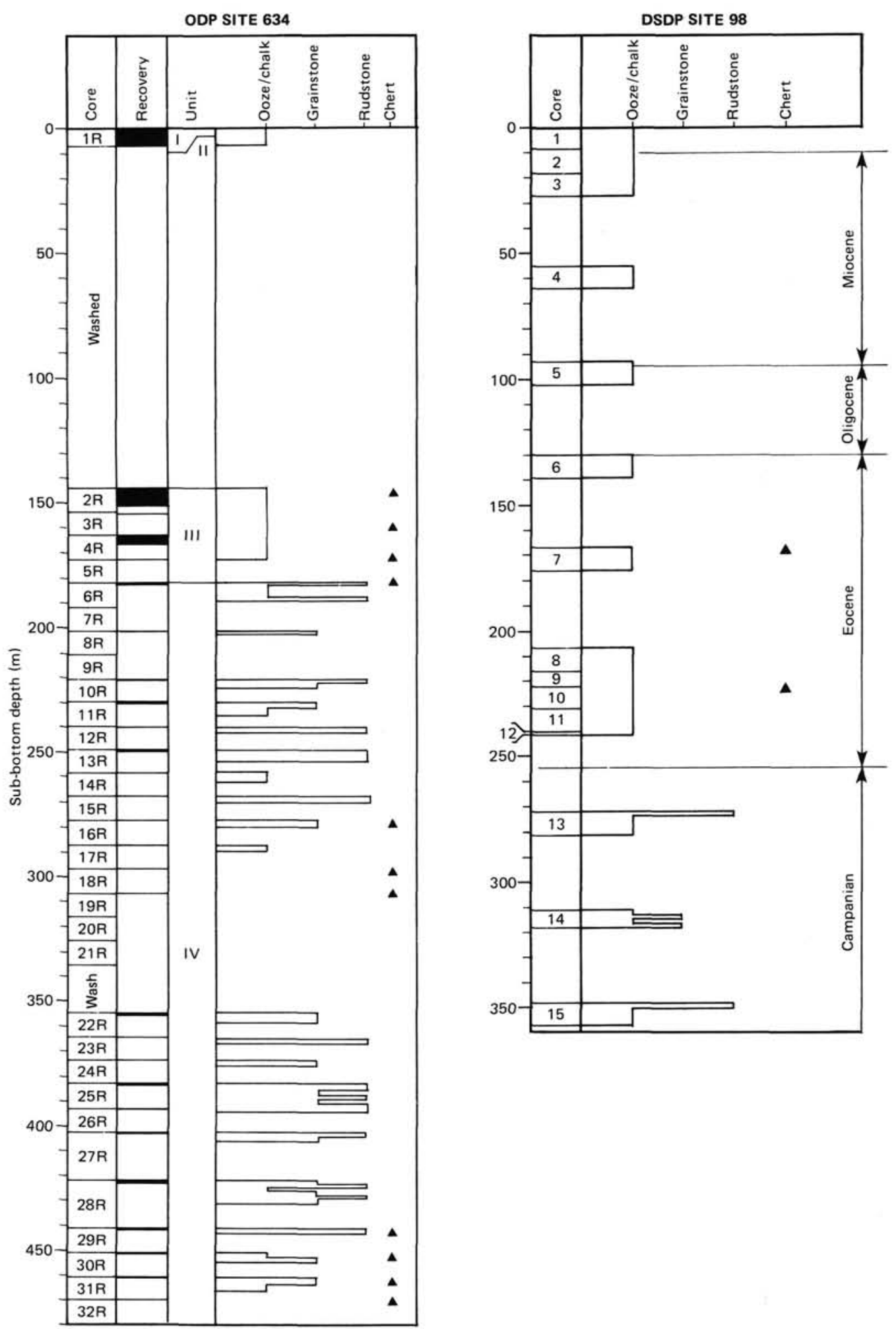

Figure 15. Lithologic comparison of ODP Site 634 and DSDP Site 98.

Core 634A-5R (182.1 m sub-bottom) was recovered empty. A thick uppermost Santonian(?)-Campanian section is present in Cores $634 \mathrm{~A}-6 \mathrm{R}$ to $634 \mathrm{~A}-32 \mathrm{R}$ (182.1-479.4 m sub-bottom). A latest Campanian age, Globotruncana calcarata Zone, is suggested for Section 634A-6R-1, based on the presence of the nominate taxon. Cores 634A-6R, CC and 634A-7R (201 m sub-bottom) are assigned to the late Campanian Globotruncana ventricosa
Zone. Diagnostic taxa include Globotruncana ventricosa, $G$. subspinosa, G. stuartiformis, G. fornicata, G. arca, G. rosetta, $G$. orientalis, and G. atlantica. Below Core 634A-7R, age determinations are sporadic owing to poor core recovery.

Core 634A-11R (239.6 m sub-bottom) is assigned to the late Campanian Globotruncana ventricosa Zone. A mid-Campanian age (lower $G$. ventricosa Zone?) is suggested for Core 634A- 
14R ( $267.8 \mathrm{~m}$ sub-bottom), based on the co-occurrence of Globotruncana sp. cf. G. elevata and $G$. subspinosa. The presence of Globotruncana elevata and G. stuartiformis in Core 634A17R ( $296.8 \mathrm{~m}$ sub-bottom) indicates the early Campanian Globotruncana elevata Zone. Core 634A-22R (364.2 m sub-bottom) is assigned an early Campanian age based on the presence of $G$. stuartiformis, $G$. sp. cf. $G$. angusticarinata, and $G$. sp. cf. $G$. orientalis. The occurrence of Globotruncana arca in Core 634A28R (441.1 m sub-bottom) suggests an age no older than Campanian for this level. A latest Santonian-earliest Campanian age is suggested for Cores 634A-30R and 634A-31R ( $469.9 \mathrm{~m}$ subbottom), based on the co-occurrence of Globotruncana stuartiformis and $G$. angusticarinata.

\section{Larger Foraminifers}

\section{Hole 634A}

The upper part of this hole was washed, so it was not possible to study the section. However, Akers (1972) identified $\mathrm{He}$ terostegina antillea, Miogypsina panamensis, Lepidocyclina (Lepidocyclina) canelli, and Camerina sp. cf. C. panamensis from Section 98-5, CC (102 m sub-bottom). This redeposited assemblage is of late Oligocene Zone NP25 (Sphenolithus ciperoensis Zone).

In Hole 634A, rare, poorly preserved Amphistegina spp. occur in Section 634A-3R, CC. This sample has been assigned to the early Eocene by planktonic foraminifers and nannofossils.

The interval from Cores 634A-6R through 634A-32R contains many pieces of rudist limestone interbedded with Campanian cherts and chalks. A thin section from Section 634A-6R-1 contains Torreina torrei and ?Sulcorbitoides sp. A thin section from the rudist limestone in Section 634A-8R, CC (210 m subbottom) contains Pseudorbitoides $\mathrm{sp}$. This genus is known from the Campanian-Maestrichtian. In thin section 634A-11R, CC (239.6 m sub-bottom), Cuneolina sp., Sulcorbitoides pardoi, and Sulcoperculina vermunti are present.

At DSDP Site 98, samples from Sections 98-13, CC (281 m sub-bottom) and 98-14-1 (318 m sub-bottom) contain Pseudorbitoides israelskyi, Orbitoides tissoti, and Ctenorbitoides cardwelli. These species are considered by Hottinger (1972) to indicate a Campanian age (Globotruncana calcarata Zone; Hollister, Ewing, et al., 1972).

Thin sections from pieces of reworked platform limestone634A-13R, 2-5 cm, 634A-25R, CC, 634-26R-1, 4-5 cm, 634A28R-1, 88-90 cm, 634A-28R-1, 100-102 cm, 634A-28R-1, 127$129 \mathrm{~cm}, 634 \mathrm{~A}-29 \mathrm{R}-1,42-45 \mathrm{~cm}$, and 634A-30R, CC-found in chalk of Campanian age with Globotruncana and nannofossils, contain Cuneolina parva, Textularidae, Discorbidae, and Miliolidae, with the algae Thaumatoporella parvovesiculifera and Baccinella irregularis. This assemblage can be assigned an age from Albian to Campanian.

The larger foraminifers recovered from Cores $634 \mathrm{~A}-6 \mathrm{R}$ to 634A-11R suggest that these limestones are derived from a Campanian platform-margin facies that was lithified and subsequently reworked into a deeper water facies during the Campanian. It is also possible, however, that the limestone clasts bearing specimens of Cuneolina parva and Baccinella irregularis (as in Cores $634 \mathrm{~A}-13 \mathrm{R}$ to $634 \mathrm{~A}-30 \mathrm{R}$ ) are derived from the erosion of an escarpment of mid-Cretaceous limestone during the Campanian.

\section{SEDIMENT-ACCUMULATION RATES}

A thin upper Pleistocene section unconformably overlies a lower Pliocene section in Core 634A-1R (Fig. 16). At least 2 m.y. is missing within this sequence. Hole $634 \mathrm{~A}$ was then washed to a depth of $144 \mathrm{~m}$ sub-bottom. An uppermost Paleocene-lower- most Eocene section is present in Cores $634 \mathrm{~A}-4 \mathrm{R}$ to $634 \mathrm{~A}-2 \mathrm{R}$. This sequence accumulated at a rate of $8-36 \mathrm{~m} / \mathrm{m}$.y., but the lower end of this range is more likely based on results from Sites 627 and 628. A stratigraphic break of about 17-18 m.y. separates Paleogene strata in Core 634A-4R from Campanian strata in Core 634A-6R. A thick section of Campanian chalk with interbedded chert and calciturbidites accumulated at an average rate of about $37 \mathrm{~m} / \mathrm{m}$.y. The upper Campanian section accumulated at an average rate of about $27 \mathrm{~m} / \mathrm{m}$.y., whereas the lower Campanian (?uppermost Santonian) section accumulated twice as rapidly with an average rate of about $60 \mathrm{~m} / \mathrm{m}$.y. Upper Campanian chalk at Site 627 accumulated at a rate similar to that of the upper Campanian of Site 634 .

\section{INORGANIC GEOCHEMISTRY}

\section{Interstitial Water}

Three samples were taken from Site 634, one from the mudline core and two from a moderately cemented chalk of late $\mathrm{Pa}-$ leocene and early Eocene age. These data show (see Table 2) only small differences from surface seawater at this site. This similarity may be a result of contamination from normal seawater, although the condition of the samples indicated that only minor amounts of modern seawater would be present.

\section{X-Ray Studies}

$\mathrm{X}$-ray studies show that aragonite was almost completely absent from Hole 634A (see Table 3 and Fig. 17). In fact, aragonite was present only in one sample taken from $1.90 \mathrm{~m}$ sub-bottom. By the next sample, at $2.90 \mathrm{~m}$ sub-bottom, it had disappeared. This contrasts with studies undertaken at DSDP Site 98 (Zemmels et al., 1972), which showed aragonite to depths of 64 $\mathrm{m}$. However, an examination of the age assignments for the two sites (see "Biostratigraphy" section, this chapter) reveals that sedimentation rates at Site 634 were extremely low compared to those of Site 98 . The disappearance of aragonite at both sites corresponds to the Pliocene/Pleistocene boundary.

A feature common to both Site 98 and Site 634 is the ubiquitous presence of clay minerals and sheet silicates in the uppermost $250 \mathrm{~m}$. These minerals were identified by Zemmels et al. (1972) as mixtures of mica, montmorillonite, chlorite, kaolinite, and palygorskite. We have identified them, however, as illitemontmorillonite mixtures, kaolinite, and/or palygorskite. Brown staining and infill of a fine-grained sediment in the Cretaceous portion of Hole $634 \mathrm{~A}$ proved to be a mixture of quartz, calcite, and dolomite.

\section{Carbonate-Bomb Data}

Only a few samples were obtained for carbonate-bomb analysis, which indicates (Fig. 18 and Table 4) that carbonate content increases downhole from less than $86 \% \mathrm{CaCO}_{3}$ in the upper $175 \mathrm{~m}$ of Hole $634 \mathrm{~A}$ to more than $96 \% \mathrm{CaCO}_{3}$ below $175 \mathrm{~m}$ sub-bottom.

\section{ORGANIC GEOCHEMISTRY}

Seven rock samples were taken for analysis using the RockEval method, and six samples were taken for analysis of hydrocarbon gases by gas chromatography. The Rock-Eval data are given in Table 5 .

All the samples taken at this site were ooze and chalk and contained little or no organic material. This scarcity of organic matter is shown by the small bitumen $\left(\mathrm{S}_{1}\right)$ and kerogen $\left(\mathrm{S}_{2}\right)$ peak values (see Table 5). The low $\mathrm{S}_{2} / \mathrm{S}_{3}$ values indicated that this kerogen was highly oxidized. $\mathrm{T}_{\max }$ values were mostly low (immature), and one overmature value was also noted. $\mathrm{T}_{\max }$ scatter indicated mixed sources of detrital organic matter. 


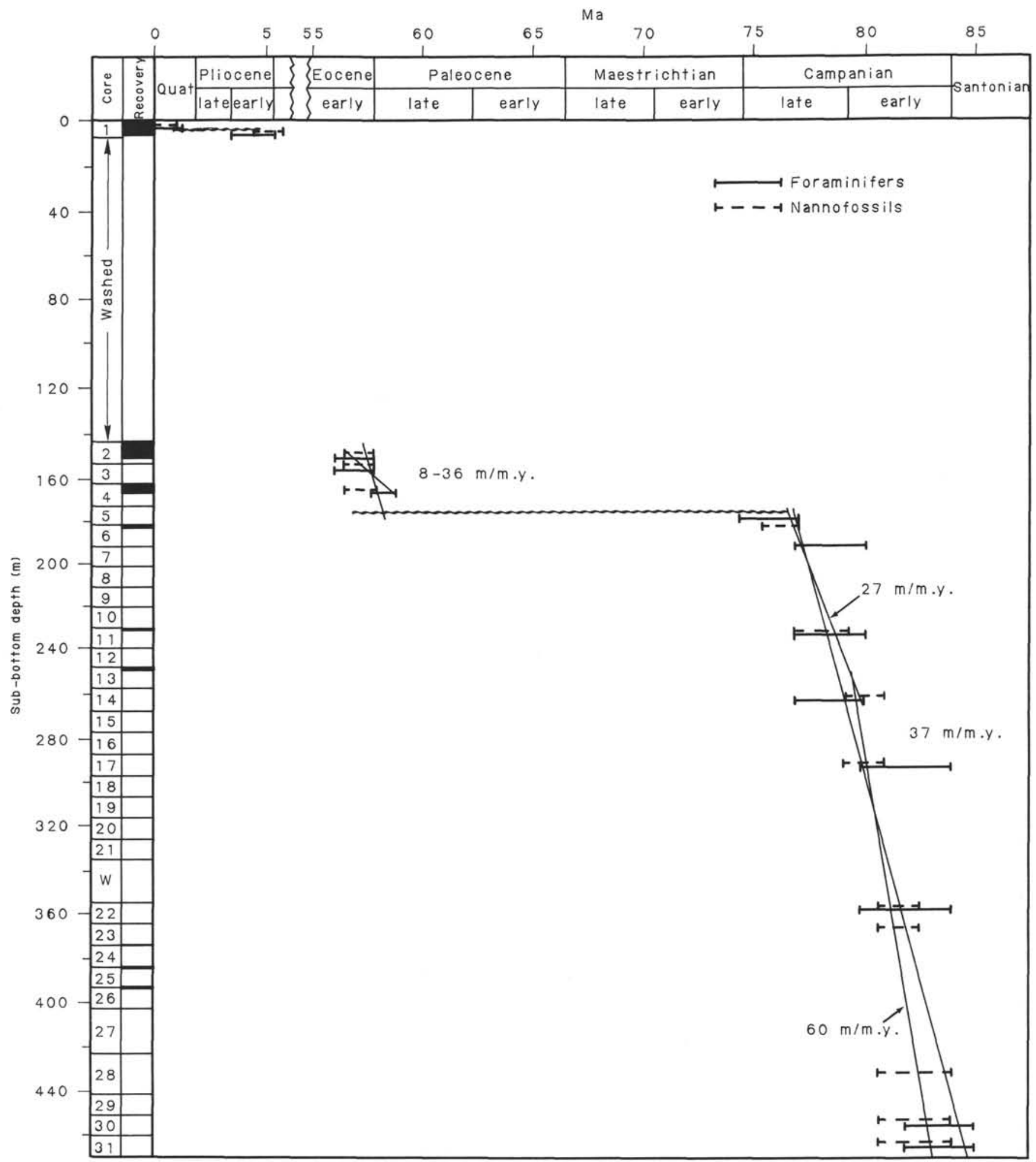

Figure 16. Sediment-accumulation rates, Site 634.

\section{PALEOMAGNETISM}

\section{Natural Remanent Magnetization}

Because of low recovery in Hole 634A, oriented paleomagnetic samples were taken only from two cores, $634 \mathrm{~A}-2 \mathrm{R}$ and $634 \mathrm{~A}-4 \mathrm{R}$. Both cores consist of lower Eocene chalk (see "Bio- stratigraphy" section, this chapter) from 144 to $170 \mathrm{~m}$ sub-bottom. In all, sixteen $12-\mathrm{cm}^{3}$ minicore samples were drilled from these sediments.

All of the samples were sufficiently magnetized so they could be measured with the shipboard Molspin spinner magnetometer. The NRM inclinations were all positive (normal polarization), 
Table 2. Analyses of interstitial waters from Hole 634A.

\begin{tabular}{cccccccc}
\hline $\begin{array}{c}\text { Sub-bottom } \\
\text { depth } \\
(\mathrm{m})\end{array}$ & $\mathrm{pH}$ & $\begin{array}{c}\text { Alkalinity } \\
(\mathrm{m}) \mathrm{kg} / \mathrm{kg})\end{array}$ & $\begin{array}{c}\text { Salinity } \\
\left(\%_{0}\right)\end{array}$ & $\begin{array}{c}\text { Chlorinity } \\
(\% \%)\end{array}$ & $\begin{array}{c}\mathrm{Ca} \\
(\mathrm{mmol} / \mathrm{L})\end{array}$ & $\begin{array}{c}\mathrm{Mg} \\
(\mathrm{mmol} / \mathrm{L})\end{array}$ & $\begin{array}{c}\mathrm{SO}_{4} \\
(\mathrm{mmol} / \mathrm{L})\end{array}$ \\
\hline Surface seawater & 8.10 & 2.426 & 35.6 & 19.52 & 10.91 & 55.47 & 27.97 \\
5.9 & 7.60 & 3.563 & 35.0 & 18.61 & 10.51 & 51.73 & 24.07 \\
149.9 & 7.54 & 2.995 & 35.4 & 19.72 & 11.57 & 51.24 & 24.47 \\
166.0 & 7.68 & 2.940 & 35.4 & 19.27 & 11.57 & 51.13 & 23.91 \\
\hline
\end{tabular}

Table 3. X-ray analyses of samples from Hole 634A.

\begin{tabular}{ccccc}
\hline $\begin{array}{c}\text { Sub-bottom } \\
\text { depth } \\
(\mathrm{m})\end{array}$ & $\begin{array}{c}\text { Calcite } \\
(\%)\end{array}$ & $\begin{array}{c}\text { Aragonite } \\
(\%)\end{array}$ & $\begin{array}{c}\text { Dolomite } \\
(\%)\end{array}$ & $\begin{array}{c}\text { Quartz } \\
(\%)\end{array}$ \\
\hline 1.9 & 45 & 45 & 0 & 10 \\
2.9 & 86 & 0 & 12 & 3 \\
5.2 & 84 & 0 & 11 & 5 \\
146.9 & 97 & 0 & 0 & 3 \\
149.5 & 97 & 0 & 0 & 3 \\
164.7 & 96 & 0 & 2 & 2 \\
164.8 & 96 & 0 & 2 & 2 \\
165.9 & 97 & 0 & 0 & 3 \\
182.4 & 100 & 0 & 0 & 0 \\
229.9 & 100 & 0 & 0 & 0 \\
230.7 & 100 & 0 & 0 & 0 \\
258.6 & 100 & 0 & 0 & 0 \\
267.6 & 100 & 0 & 0 & 0 \\
354.7 & 100 & 0 & 0 & 0 \\
373.8 & 100 & 0 & 0 & 0 \\
441.1 & 95 & 0 & 3 & 2 \\
\hline
\end{tabular}

a Illite-montmorillonite, kaolinite, and palygorskite(?) occur generally in the upper $250 \mathrm{~m}$.

and most were steeper than the present geocentric axial dipole inclination for Site $634\left(43.3^{\circ}\right)$. The polarity of the samples seemed wrong, because the nannoplankton zone to which the sediments belong, NP10 (see "Biostratigraphy" section, this chapter), falls squarely within a $2.5-\mathrm{m} . \mathrm{y}$. period of reversed magnetic-field polarity (Harland et al., 1982). One sample was placed in the shipboard Schonstedt alternating-field demagnetizer and was demagnetized at 50 and $100 \mathrm{Oe}$. The magnetization of the sample dropped half an order of magnitude, from $4.9 \times 10^{-5}$ emu to $0.7 \times 10^{-5}$ emu. Moreover, the polarity of the sample reversed, its inclination changing from $79.1^{\circ}$ to $-23.0^{\circ}$. This observation suggests that the samples are overprinted with a secondary magnetization that must be removed by magnetic cleaning techniques in order to measure the primary magnetization. Because the demagnetization test reduced the intensity of the magnetization of the sample to a value close to the noise level of the shipboard spinner magnetometer, further work on these samples was postponed for later measurement on a cryogenic magnetometer.

\section{Magnetic Susceptibility}

Whole-core susceptibility measurements were taken at $10-\mathrm{cm}$ intervals along Cores 634A-1R, 634A-2R, 634A-4R, 634A-6R, and $634 \mathrm{~A}-28 \mathrm{R}$. Because of poor recovery in Hole $634 \mathrm{~A}$, these were the only cores measured. The susceptibility values from Core $634 \mathrm{~A}-1 \mathrm{H}$, which extends to $6.4 \mathrm{~m}$ sub-bottom, were higher than expected for carbonate-rich sediments. The section averages for this core ranged from $0.9 \times 10^{-6} \mathrm{G} / \mathrm{Oe}$ to $2.8 \times 10^{-6}$ $\mathrm{G} / \mathrm{Oe}$, values similar to those recorded in the upper parts of Holes 627B, 632A, and 633A. The susceptibility values from the other Hole 634A cores were either slightly paramagnetic, with averages near $0.2 \times 10^{-6} \mathrm{G} / \mathrm{Oe}$ to $0.6 \times 10^{-6} \mathrm{G} / \mathrm{Oe}$, or slightly diamagnetic, with averages near $-0.2 \times 10^{-6} \mathrm{G} / \mathrm{Oe}$.

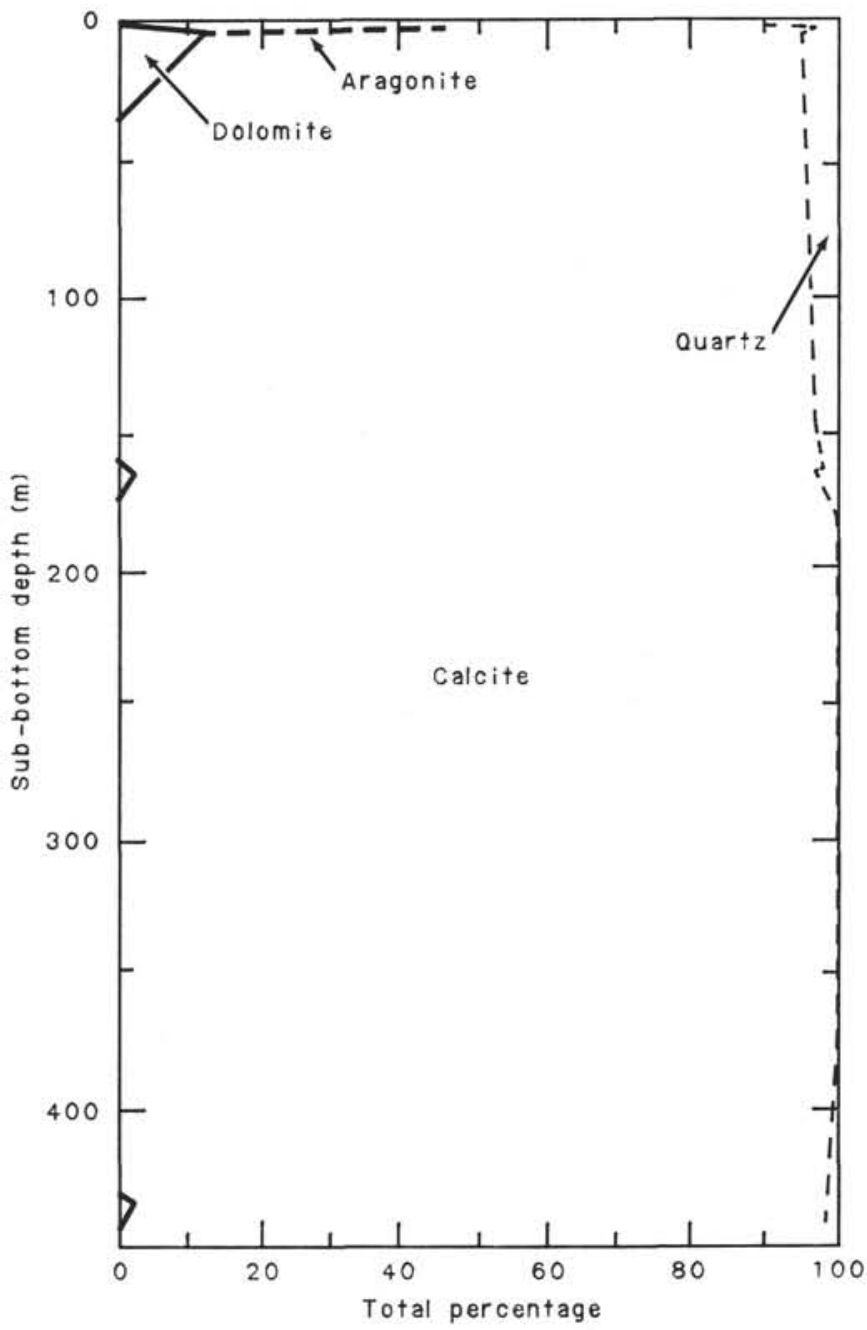

Figure 17. X-ray data, Site 634.

These values are typical of carbonate sediments measured in other holes on Leg 101.

\section{PHYSICAL PROPERTIES}

Physical properties were measured on sediment and rock recovered from Site 634 as described in the "Introduction and Explanatory Notes" (this volume). A complete series of physicalproperty measurements was made on the mud-line core $(634 \mathrm{~A}$ $1 \mathrm{R})$ with results tabulated in Table 6 . Sediments recovered from Core $634 \mathrm{~A}-2 \mathrm{R}$ at $144 \mathrm{~m}$ sub-bottom and deeper were too indurated for thermal-conductivity and shear-strength measurements, but compressional wave velocity measurements were made. However, in order to conserve sample material as a result of poor recovery, few index-property measurements were made by gravimetric and volumetric techniques. Wet-bulk density and porosi- 


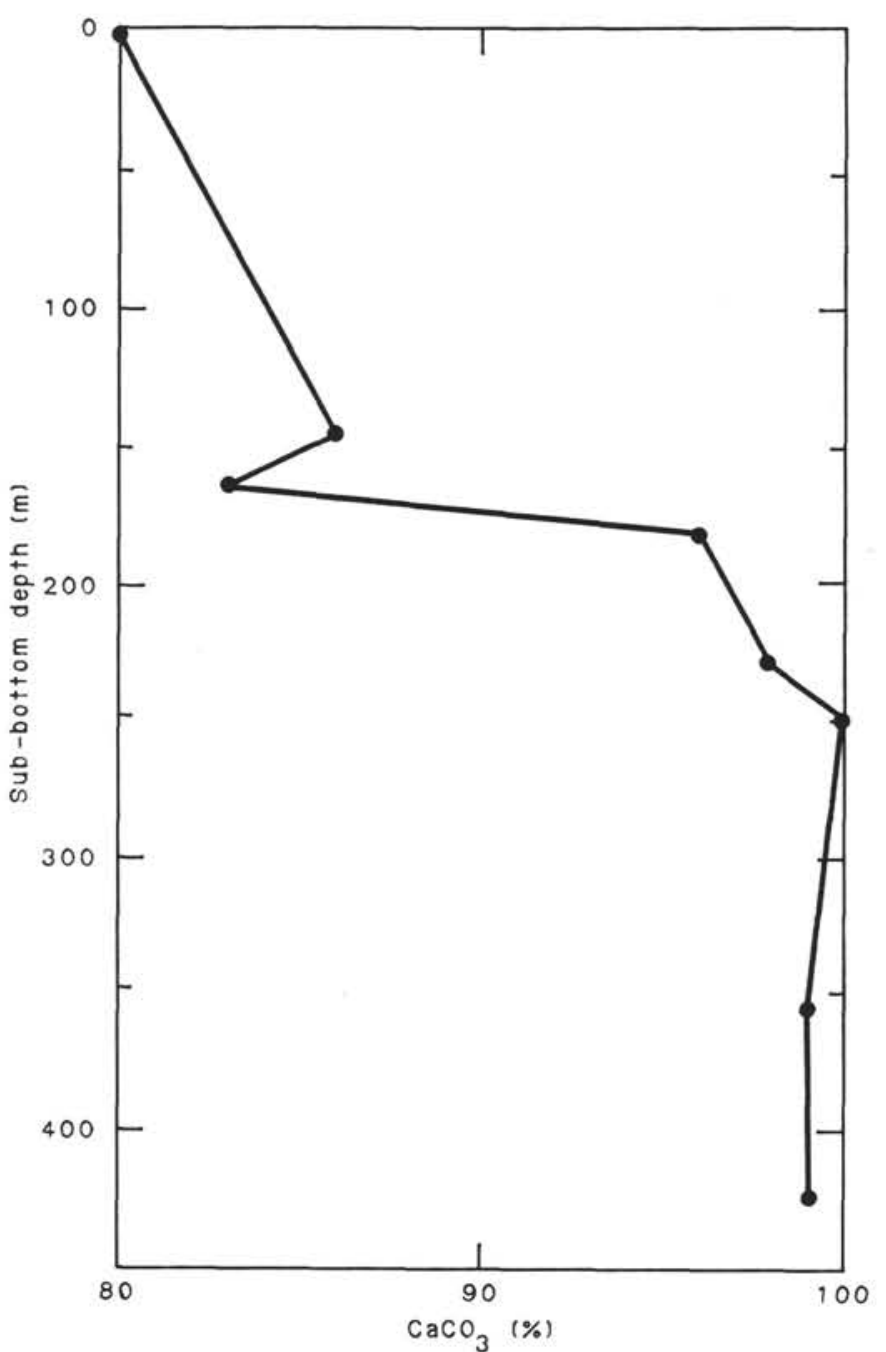

Figure 18. Carbonate-bomb data, Site 634.

\begin{tabular}{cc}
$\begin{array}{c}\text { Table 4. Carbonate- } \\
\text { bomb data, Site 634. }\end{array}$ \\
\hline $\begin{array}{c}\text { Sub-bottom } \\
\text { depth } \\
\text { (m) }\end{array}$ & $\begin{array}{c}\mathrm{CaCO}_{3} \\
\text { content } \\
(\%)\end{array}$ \\
\hline 2.2 & 80 \\
146.2 & 86 \\
165.3 & 83 \\
182.4 & 96 \\
230.4 & 98 \\
249.1 & 100 \\
355.0 & 99 \\
422.4 & 99 \\
\hline
\end{tabular}

ty were primarily determined by 2 -min counts with the Gamma Ray Attenuation Porosity Evaluator (GRAPE). In the downhole-distribution curve of Figure 19, values determined by both techniques are illustrated. As a result of drilling operations at Site 634 (washing between 6.4 and $144 \mathrm{~m}$ sub-bottom) and poor recovery, physical-property parameters represent only selective samples of the drilled section.

\section{Compressional Wave Velocity}

Compressional wave velocity measurements fall into three groups (Fig. 20). In the mud-line core, velocity averages 1600
Table 5. Organic-geochemical (Rock-Eval) values, Site 634. ${ }^{\mathrm{a}}$

\begin{tabular}{clllll}
\hline $\begin{array}{c}\text { Sub-bottom } \\
\text { depth } \\
(\mathrm{m})\end{array}$ & $\mathrm{S}_{1}$ & $\mathrm{~S}_{2}$ & $\mathrm{~S}_{3}$ & $\begin{array}{c}\mathrm{T}_{\max } \\
\left({ }^{\circ} \mathrm{C}\right)\end{array}$ & $\mathrm{S}_{2} / \mathrm{S}_{3}$ \\
\hline 0.8 & 0.05 & 0.15 & 5.68 & 379 & 0.02 \\
3.8 & 0.05 & 0.17 & 2.24 & 362 & 0.07 \\
146.3 & 0 & 0 & 0.97 & 391 & - \\
150.8 & 0 & 0.02 & 0.35 & 284 & 0 \\
164.6 & 0.03 & 0.18 & 1.07 & 494 & 0.16 \\
182.4 & 0.04 & 0.13 & 0.64 & 284 & 0.20 \\
230.45 & 0.03 & 0.16 & 0.39 & 421 & 0.41 \\
\hline a For a more complete explanation, see Table 6, Site \\
626 chapter.
\end{tabular}

$\mathrm{m} / \mathrm{s}$. Between 144 and $184 \mathrm{~m}$ sub-bottom, most of the values are clustered around $2000 \mathrm{~m} / \mathrm{s}$. These values represent chalk recovered in this interval. Velocities between 3000 and $4000 \mathrm{~m} / \mathrm{s}$ were measured in three chert layers interbedded in the chalk. Below $230 \mathrm{~m}$ sub-bottom, the velocity varies between 1600 and 6000 $\mathrm{m} / \mathrm{s}$. This wide range correlates with the lithology and cementation of recovered sediment. Low values between 1600 and 2500 $\mathrm{m} / \mathrm{s}$ are recorded from chalks and partly lithified grainstones. Velocities between 2500 and $3500 \mathrm{~m} / \mathrm{s}$ are recorded from cemented grainstones and rudstones. Velocities between 4500 and $6000 \mathrm{~m} / \mathrm{s}$ were recorded from chert as well as from hard rudstones and boundstones that probably represent shallow-waterlimestone clasts washed out from debris flows ("Sedimentology" section, this chapter). Anisotropy is evident in numerous samples, with velocities measured parallel to bedding being up to $80 \mathrm{~m} / \mathrm{s}$ higher than those measured perpendicular to bedding (Fig. 20). Further shore-based work is required to clarify this finding.

\section{Wet-Bulk Density, Porosity, and Water Content}

In the mud-line core, water content and porosity average $60 \%$, and wet-bulk density averages $1.63 \mathrm{~g} / \mathrm{cm}^{3}$ (Fig. 19). Between 144 and $230 \mathrm{~m}$ sub-bottom, bulk-density values range from 1.84 to $2.07 \mathrm{~g} / \mathrm{cm}^{3}$, with the average value being $2.0 \mathrm{~g} / \mathrm{cm}^{3}$. Water content ranges from $40 \%$ to $30 \%$, and porosity from $53 \%$ to $45 \%$.

Below $248 \mathrm{~m}$ sub-bottom, a pronounced decrease in density occurs. Values shift from 2.2 to $2.6 \mathrm{~g} / \mathrm{cm}^{3}$. Porosity and dry water content are correspondingly low. Water content was measured on only three samples below $240 \mathrm{~m}$ sub-bottom; values average $16 \%$. Wet-bulk density and porosity were determined by GRAPE and display values between 2.2 and $2.5 \mathrm{~g} / \mathrm{cm}^{3}$.

\section{Discussion}

The shift at $240 \mathrm{~m}$ sub-bottom reflects the change from chalks to lithified, cemented grainstones. Although a few chalks were present below $240 \mathrm{~m}$ sub-bottom, measurements were made only on lithified grainstones. The sampling was dictated by poor recovery and the need to preserve core material and does not reflect the lithologic variability below $240 \mathrm{~m}$ sub-bottom.

\section{DOWNHOLE MEASUREMENTS}

With the hole conditions at Site 634 similar to those at Hole $626 \mathrm{~B}$, the decision was made to limit the logging runs to those tools which could be run in the pipe. These logging runs covered the interval from 0 to $151 \mathrm{~m}$ sub-bottom with a compensatedneutron (CNL) and gamma-ray (GR) combination, and the interval from 151 to $409 \mathrm{~m}$ sub-bottom with a gamma-spectrometry (GST), CNL, and GR combination. The CNL is similar to the CNTG used in Holes 626B and 627B, except that the CNL measures only thermal neutron porosity and not epithermal. The GST is an induced gamma-spectrometry tool that bom- 
Table 6. Physical properties of sediments, Site 634.

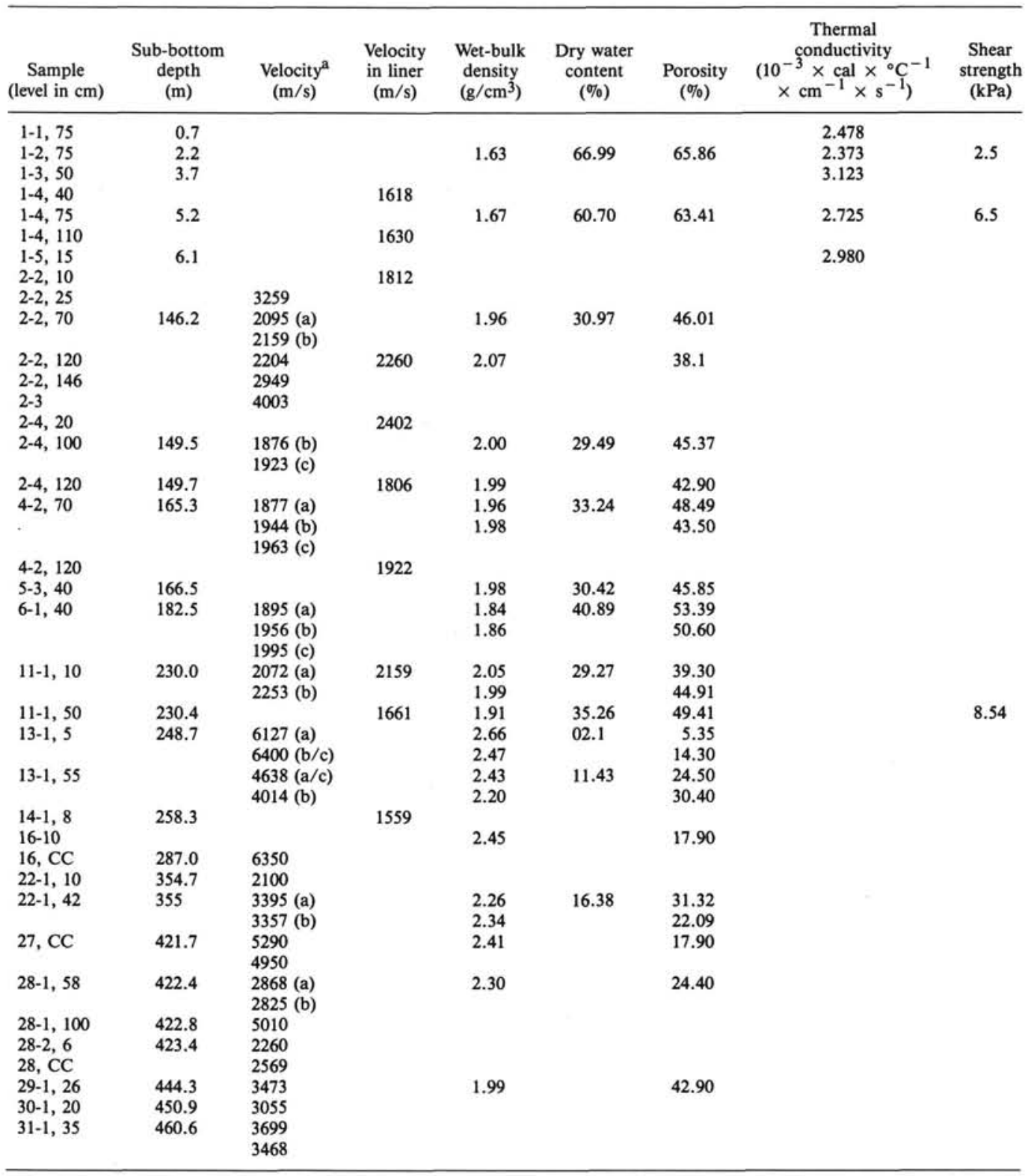

a See footnote to Table 9, Site 627 chapter.

bards the formation with high-energy neutrons and records the gamma-ray spectrum generated by the neutron interactions. The recorded spectra are then used to detect the presence of carbon $(C)$, oxygen $(\mathrm{O})$, silicon $(\mathrm{Si})$, calcium $(\mathrm{Ca})$, sulfur $(\mathrm{S})$, chlorine $(\mathrm{Cl})$, hydrogen $(\mathrm{H})$, and iron $(\mathrm{Fe})$ in addition to porosity and the total neutron capture cross section of the formation. The count rates generated by the GST can be displayed directly or in ratios which indicate changes in lithology, salinity, and porosity (Westaway et al., 1980).

A total of 10 passes were made with the GST, 5 in the capture-tau mode over the interval from 151 to $409 \mathrm{~m}$ sub-bottom and 5 in the inelastic mode in the intervals from 246 to $251 \mathrm{~m}$ sub-bottom and 370 to $383 \mathrm{~m}$ sub-bottom. In the capture-tau mode, measurements are made of $\mathrm{H}, \mathrm{Si}, \mathrm{Ca}, \mathrm{Cl}, \mathrm{Fe}, \mathrm{S}$, and the neutron capture cross section, while the inelastic mode measures $\mathrm{C}, \mathrm{O}, \mathrm{Si}, \mathrm{Ca}, \mathrm{S}$, and $\mathrm{Fe}$.

\section{Log Characterization}

Figure 21 displays the neutron porosity curve and the standard gamma-ray curve for the interval 0 to $409 \mathrm{~m}$ sub-bottom; 10 separate zones of relatively constant porosity can be identified within this interval. Average core porosity measurements from the same intervals are included in parentheses for each value given below (see "Physical Properties" section, this chapter). From 0 to $167 \mathrm{~m}$ sub-bottom, the porosity averages $75 \% \pm$ $15 \%(55 \% \pm 10 \%)$, owing to poor hole conditions. A zone from 167 to $223 \mathrm{~m}$ sub-bottom exhibits an average porosity of $60 \% \pm 10 \%(60 \%)$; this porosity value is interrupted between 175 and $181 \mathrm{~m}$ sub-bottom and between 185 and $191 \mathrm{~m}$ sub-bottom by zones with porosities of approximately $70 \%$. The fourth zone lies between 223 and $239 \mathrm{~m}$ sub-bottom, with porosities averaging $67 \% \pm 10 \%$ (no measurements), and this is followed by 
- Determined by gravimetric and volumetric techniques

$\triangle$ Determined by GRAPE (2-min counts)
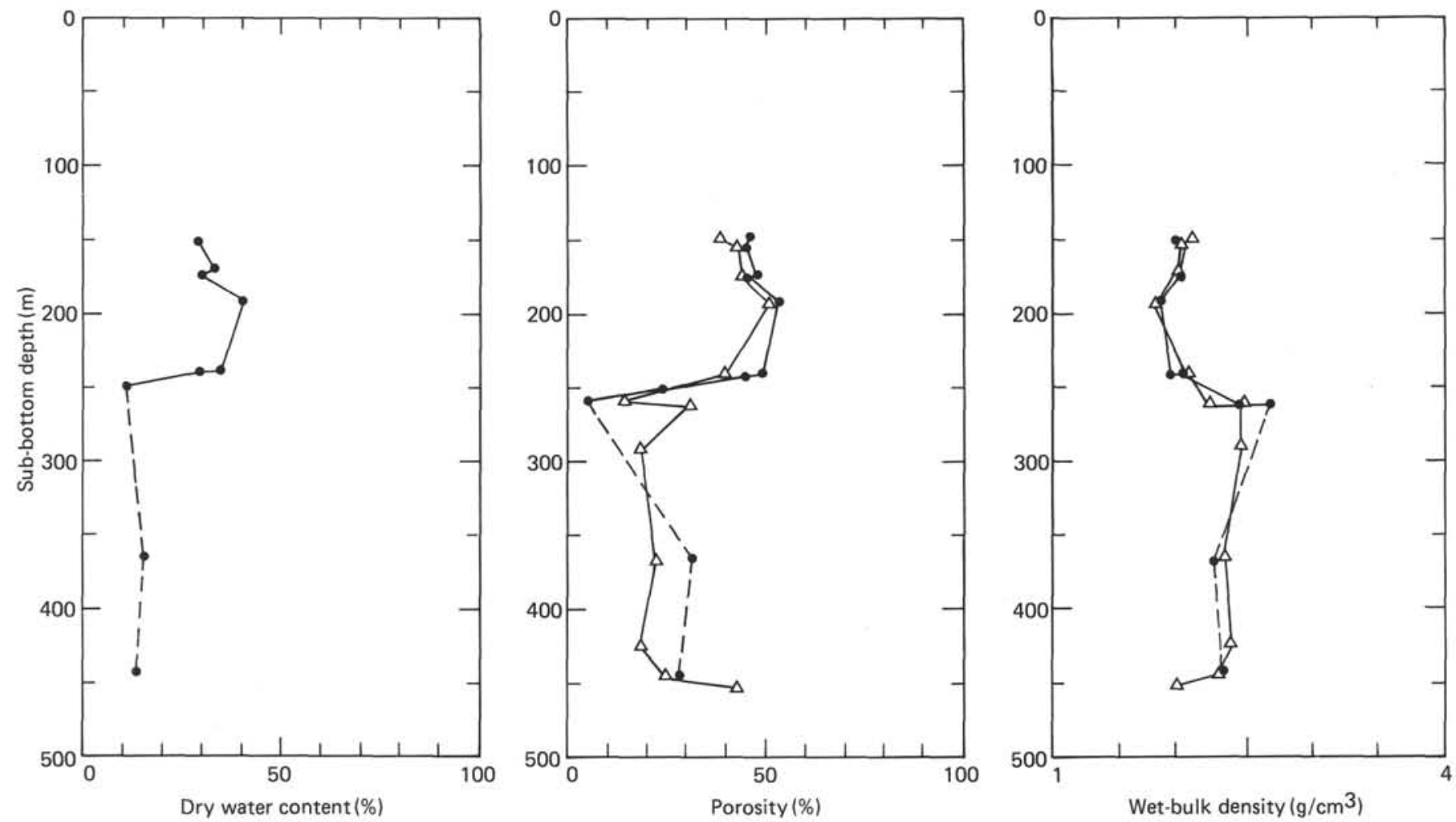

Figure 19. Dry water content, porosity, and wet-bulk density, Site 634.

porosities averaging $50 \% \pm 10 \%(45 \%)$ from 239 to $252 \mathrm{~m}$ subbottom. At this point the curve becomes highly variable, oscillating between $50 \%$ and $75 \%$ (no measurements) between 252 and $329 \mathrm{~m}$ sub-bottom. From 329 to $339 \mathrm{~m}$ sub-bottom the porosity averages $40 \% \pm 5 \%$ (no measurements), and from 339 to $376 \mathrm{~m}$ sub-bottom the average increases to $57 \% \pm 10 \%$ (one measurement of $30 \%$ ). Finally, the porosity dips to $45 \% \pm 10 \%$ (no measurements) between 376 and 409 m sub-bottom.

The count rates measured during the third GST pass are given in Figure 22; the eight curves displayed are the count rates for sulfur (CSUL), iron (CFE), chlorine (CCHL), calcium (CCA), hydrogen ( $\mathrm{CHY}$ ), and silicon (CSI), along with the background gamma radiation (GR) and the formation capture cross section (CSIG). The neutron capture cross section curve is sensitive to the presence of hydrogen surrounding the drill string, so it is a good indicator of borehole size. An examination of that curve shows large hole diameters in the intervals from 175 to $179 \mathrm{~m}$, 184 to $187 \mathrm{~m}, 188$ to $190 \mathrm{~m}, 223$ to $237 \mathrm{~m}, 255$ to $260 \mathrm{~m}, 270$ to $273 \mathrm{~m}, 277$ to $317 \mathrm{~m}, 343$ to $353 \mathrm{~m}$, and 359 to $369 \mathrm{~m}$. These intervals show up in the other curves as increases in CHY and CCHL and decreases in CCA.

The CSUL curve stays close to zero for the entire logging interval, a result consistent with the lithology determined through core analysis (see "Sedimentology" section, this chapter). By contrast, the CFE curve gives consistently higher values (averaging between 0.05 and 0.10 ), and at many points, most notably between 329 and $339 \mathrm{~m}$ sub-bottom, peaks to values approaching 0.25 . It should be noted that the bottom-hole assembly (BHA) was positioned starting at $319 \mathrm{~m}$ sub-bottom and that this caused a general increase in CFE, GR, and CSI and a decrease in CCHL and CHY. Despite this effect, CSI generally increases in value with depth.
Figure 23 shows the GST curves in terms of ratios, which are intended to provide insight into variations of lithology within the hole. The equations for the determination of each ratio are given in Table 7. The salinity-indicating ratio (SIR) follows a relatively constant value of 2.5 except for the section of the hole corresponding to the BHA. The porosity-indicating ratio (PIR) clearly responds to the presence of the washed-out zones mentioned above, but in the rest of the hole it corresponds fairly well to the neutron porosity curve. The iron-indicating-ratio (IIR) curve is consistent in shape with the CFE curve given in Figure 22 . For the lithology-indicating ratio (LIR), a value of 1.0 corresponds to pure sandstone, and a value of 0.0 corresponds to pure limestone. In this case the LIR varies between 0.0 and 0.3 , values that indicate a formation consisting of nearly pure calcite. This pattern changes at the BHA, where the increased thickness of iron causes a jump in the quantity of silicon indicated by the log. This jump is due to distortion of the measured spectra by the large quantity of iron in the BHA.

\section{Interpretation}

A general interpretation of the count rates displayed above is made possible through the use of Schlumberger's Quicklook program. This program scales the data from the initial count rates and presents estimates of the various formation constituents. The results of a Quicklook study of the third capture-tau pass are shown in Figure 24. The curves in the first and second tracks are repeat plots of IIR, GR, PIR, and CNL porosity. The stippled areas between the PIR and CNL porosity curve are indicators of probable washed-out zones. Porosity, percentage of calcite, and percentage of chert are displayed in the third track, with the high porosity values resulting from having run the CNL in the drill pipe (see "Downhole Measurements" section, Site 


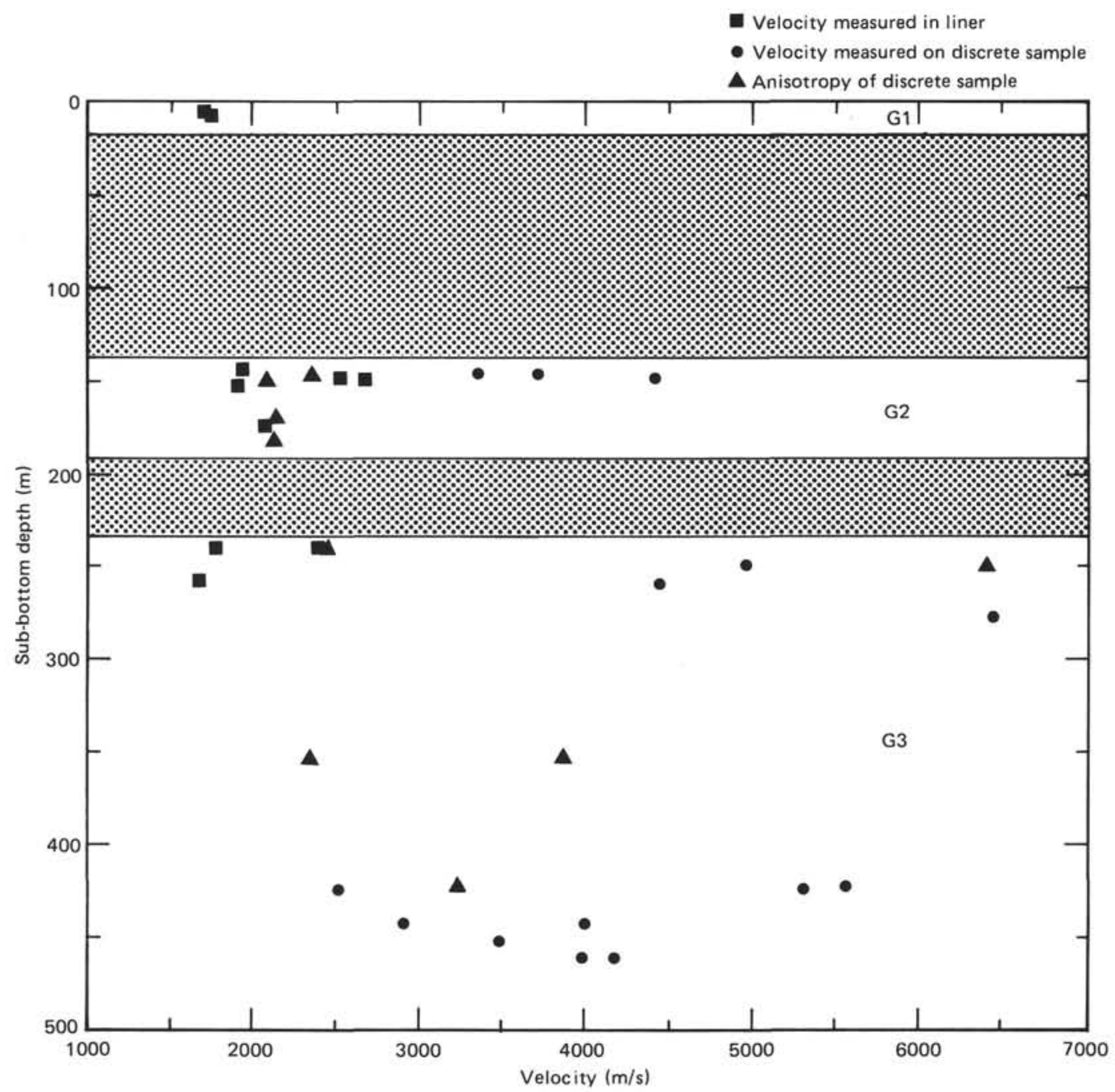

Figure 20. Velocity distribution at Site 634 (shaded areas indicate sections of no recovery). $G 1=$ mudline core; $G 2$ = group with bimodal values (chalk and chert); $G 3$ = group with great variations (pelagic chalk and limestones with cherts and intercalations of turbidites).

626 chapter). The formation consists almost completely of calcite, except for a few intervals of what appear to be chert layers. A comparison of the location of cores that recovered chert with the lithology curve clearly shows the correspondence of recovered chert to the chert layers indicated by the log.

Below the beginning of the BHA, between 329 and $339 \mathrm{~m}$ sub-bottom, an interval of high iron content and low porosity (approximately $45 \%$ ) occurs. At first, this variation was thought to be a product of the presence of the BHA, but in the fifth pass the drill string was moved up $4 \mathrm{~m}$, moving the shifts in PIR, LIR, and CNL porosity without affecting the placement of the high-iron-low-porosity zone. Thus, this zone is a characteristic of the formation, but the significance of the iron peak is not clear at the present time, as there was no recovery in the two cores covering the interval (see "Sedimentology" section, this chapter).

\section{SEISMIC STRATIGRAPHY}

\section{Introduction}

All three Northwest Providence Channel sites were not originally primary drilling targets of Leg 101 . As a result, no site- specific surveys were conducted for them. Site 634 , a reoccupation of DSDP Site 98, was originally approved as an alternate for DSDP Leg 76. Only when poor hole conditions forced premature abandonment of Site 634 were Sites 635 and 636, both modifications of BAH-3-A, selected for successive attempts to sample the previously interpreted mid-Cretaceous shallow-water-carbonate platform inferred to lie beneath Northeast Providence Channel (Sheridan et al., 1981; Fig. 25). Unfortunately, all three sites were unsuccessful in reaching the platform top. Nonetheless, some recalibration of regional seismic markers was made possible by Site 634 results, and Albian slope sediments recovered at Site 635 provide both a stratigraphic tie with Site 627 and force a modification of the "megaplatform" hypothesis to accommodate diachronous drowning in the northwestern Bahamas.

\section{Site 634}

As has already been stated, no new regional or site-specific geophysical data were collected for Leg 101 in the vicinity of DSDP Site 98. LDGO regional multichannel seismic lines 94 and 334 (Figs. 25 and 26; see Fig. 3 for locations) were used for siting purposes. Based on results from Site 634, the following observations can be made. 


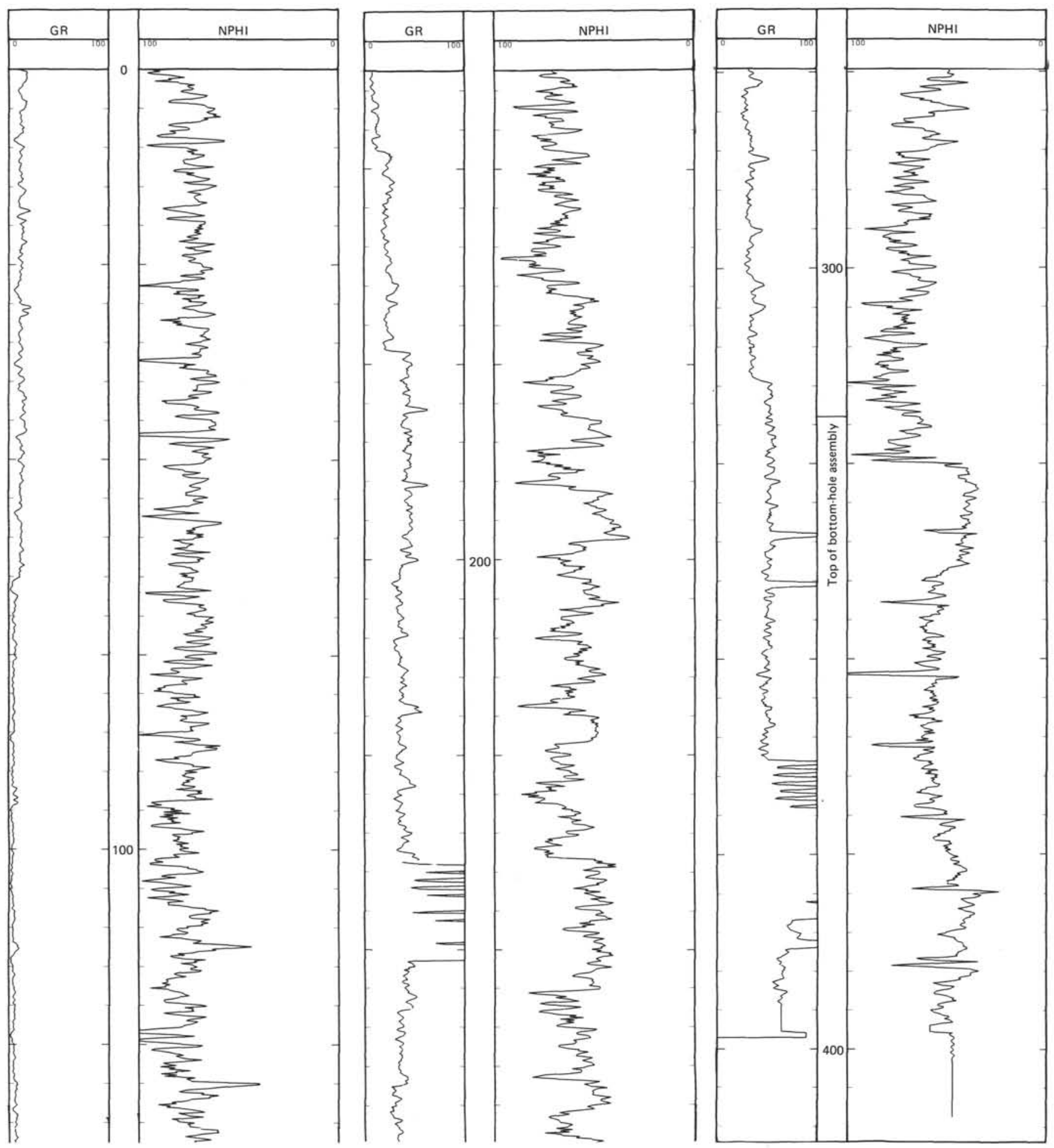

Figure 21. Neutron porosity (NPHI) and gamma-ray (GR) log for Hole 634A. The off-scale peaks in the gamma-ray curve represent positions of inelastic stations. The high value for the gamma-ray curve results from formation activation by the GST. Depth in meters.

1. The upper Eocene/upper Oligocene sequence boundary of Sheridan et al. (1981) is older than previously thought. At Site 634 , this boundary falls at $0.19 \mathrm{~s}$ sub-bottom (Fig. 25 ). This converts to a depth of $176 \mathrm{~m}$ sub-bottom in Hole $634 \mathrm{~A}$, based on the $1.85-\mathrm{km} / \mathrm{s}$ interval velocity used to stack line 94 (Fig. 25 , inset). Therefore, this acoustic horizon ties in depth either to the Paleocene/Eocene contact in Core 634A-4R (163.1-172.4 m sub- bottom) or to the top of the late Campanian at 172.4-191.5 m sub-bottom. At nearby Site 98, the same acoustic horizon occurs at $194 \mathrm{~m}$ sub-bottom, which puts it within the Eocene.

2. The same conclusion can be reached concerning the lower Eocene/upper Eocene sequence boundary of Sheridan et al. (1981), which falls at $0.295 \mathrm{~s}$ sub-bottom on line 94 at Site 634 (Fig. 25). Again assuming a conversion velocity of $1.85 \mathrm{~km} / \mathrm{s}$ 


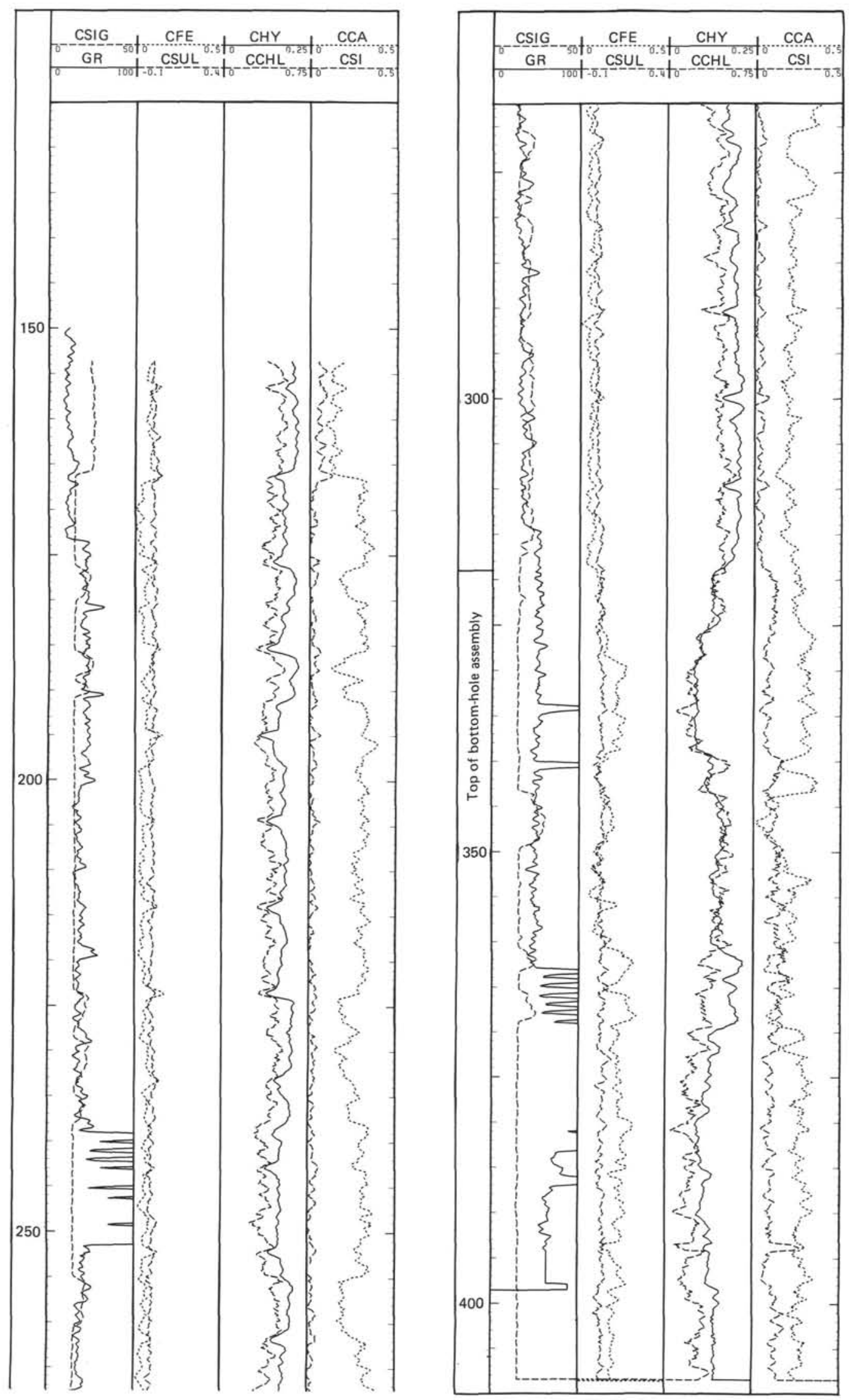

Figure 22. Count-rate curves from the third GST pass. Note how pipe collars and the bottom-hole assembly affect the data. Depth in meters. 

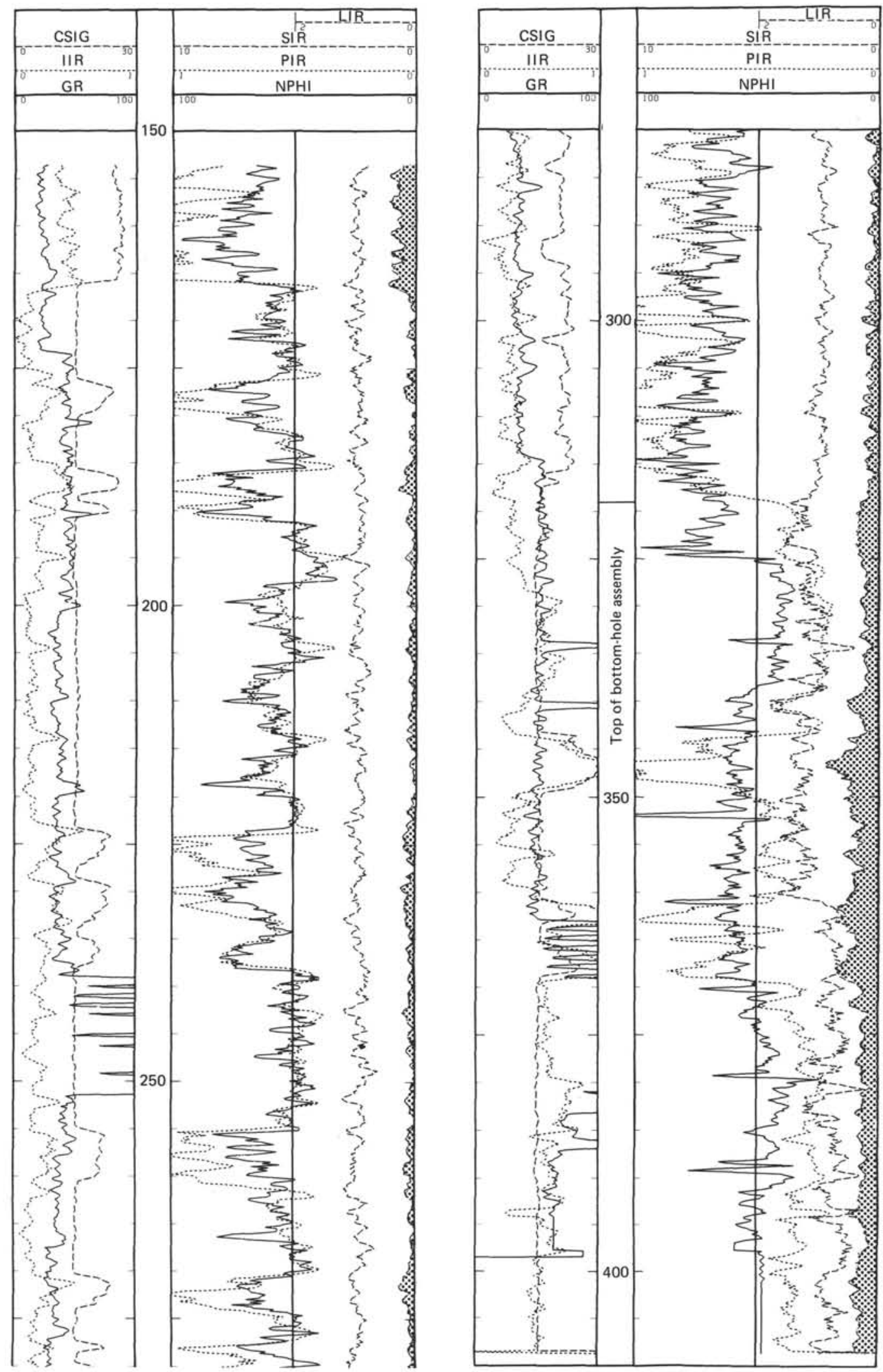

Figure 23. Ratio curves from the third GST pass. Note how washed-out intervals are indicated by CSIG and PIR. Depth in meters. 
Table 7. Ratios and their equations computed in GST capture-tau passes. ${ }^{\text {a }}$

\begin{tabular}{ll}
\hline \multicolumn{1}{c}{ Ratio } & Corresponding equation \\
\hline Porosity-indicating ratio (PIR) & $\mathrm{CHY} /(\mathrm{CCA}+\mathrm{CSI})$ \\
Lithology-indicating ratio (LIR) & $\mathrm{CSI} /(\mathrm{CCA}+\mathrm{CSI})$ \\
Salinity-indicating ratio (SIR) & $\mathrm{CCHL} / \mathrm{CHY}$ \\
Iron-indicating ratio (IIR) & $\mathrm{CFE} /(\mathrm{CCA}+\mathrm{CSI})$ \\
\hline
\end{tabular}

a Abbreviations: GST = gamma-spectrometry tool; $\mathrm{CHY}=$ count rate for hydrogen; $\mathrm{CCA}=$ count rate for calcium; $\mathrm{CSI}=$ count rate for silicon; $\mathrm{CCHL}=$ count rate for chlorine; $\mathrm{CFE}=$ count rate for iron.

(Fig. 25, inset), this traveltime suggests a depth of $273 \mathrm{~m}$ subbottom. At present, this lower sequence boundary is correlated to both a pronounced decrease in drilling rates and formation porosity and an increase in compressional wave velocities (measured on hand specimens by the Hamilton Frame; see "Physical Properties" section, this chapter), which occurs at approximately $250 \mathrm{~m}$ sub-bottom in Hole $634 \mathrm{~A}$. These physical discontinuities may be caused by the presence of cherty zones within the interval of Campanian calciturbidites sampled at Site 634 (see "Sedimentology" section, this chapter).

At DSDP Site 98, a chert zone occurs at approximately 300 $\mathrm{m}$ sub-bottom, which once again places it within the Campanian interval sampled there (Hollister, Ewing, et al., 1972).

3. The top of the inferred shallow-water-carbonate platform previously discussed occurs at Site 634 at $0.635 \mathrm{~s} / 770 \mathrm{~m}$ subbottom. Unfortunately, this surface was not reached at Site 634, necessitating operations at Sites 635 and 636.

\section{SUMMARY AND CONCLUSIONS}

Hole 634A represents an attempt to deepen DSDP Hole 98 to the mid-Cretaceous carbonate platform inferred to underlie both banks and basins in the northwestern Bahamas. Only one hole was drilled. It is $500 \mathrm{~m}$ north (i.e., downslope) from DSDP Hole 98 (Hollister, Ewing, et al., 1972), and it penetrated $479 \mathrm{~m}$ of Cenozoic and Cretaceous sediments.

From top to bottom, the sequence penetrated at Site 634 consists of the following lithologic units (Fig. 27 and "Sedimentology" and "Biostratigraphy" sections, this chapter): (1) periplatform ooze and carbonate ooze devoid of aragonite, some calcitic chalk with hardground, early Pliocene to Pleistocene, $6 \mathrm{~m} \mathrm{(12}$ $\mathrm{m}$ in DSDP Hole 98); (2) washed to $144 \mathrm{~m}$; (3) nannofossil chalk with chert nodules, late Paleocene to early Eocene, $38 \mathrm{~m}$; and (4) alternation of nannofossil chalk and detrital limestones with some chert; limestones consist of skeletal grainstones and rudstones, interpreted as turbidites, and of rudstones with pebble-sized clasts of shallow-water limestones in a chalk matrix, tentatively interpreted as debris flows; proportions of these lithologies in the formation are not well known because of low recovery; age is early to late Campanian, $297 \mathrm{~m}$.

Based on the similarity to deposits on modern Bahamian platform flanks, we interpret the basal unit of chalk and turbidites as the debris apron of a carbonate platform. The sedimentation rate in the turbidite sequence is $27-60 \mathrm{~m} / \mathrm{m}$.y., comparable to modern Bahamian basin fills ("Sediment-Accumulation Rate" section, this chapter; Droxler and Schlager, in press). The turbidite apron grades upward into a carbonate slope that was being bypassed by turbidity currents and was characterized by slowly accumulating carbonate ooze. In Hole 634A the sedimentation rate is between 8 and $36 \mathrm{~m} / \mathrm{m}$.y. but is poorly constrained because of the washed interval. At the better documented DSDP Site 98, Hollister, Ewing, et al. (1972) calculate $7 \mathrm{~m} / \mathrm{m}$.y. for this part of the section. The transition from basin floor to slope may reflect the combined effects of upbuilding (and prograding?) of the Cretaceous Bahama Bank and the downward cutting of the nearby Great Bahama Canyon (Schlager and Ginsburg, 1981).

Hole $634 \mathrm{~A}$ penetrated two prominent seismic reflectors. The upper one can be confidently tied to the top of the upper Campanian turbidite sequence at $144 \mathrm{~m}$; the other corresponds probably to an abrupt increase of hard turbidites within this formation and a concomitant increase in drilling rate and sonic velocities at 250 m ("Sedimentology" and "Physical Properties" sections, this chapter). Using a tie to Site 98, Sheridan et al. (1981) had dated the upper reflector as late Eocene-late Oligocene and the lower as early-late Eocene. These age interpretations are not compatible with our drilling results.

CNL and GST logs run in the pipe provide continuous information on porosity and basic lithologies and partly compensate for the poor core recovery ("Seismic Stratigraphy" section, this chapter).

\section{REFERENCES}

Akers, W. H., 1972. Larger foraminifers from Hole 98. In Hollister, C. D., Ewing, J. I., et al., Init. Repts. DSDP, 11: Washington (U.S. Govt. Printing Office), 545-546.

Andrews, J. E., Shepard, F. P., and Hurley, R. J., 1970. Great Bahama Canyon. Geol. Soc. Am. Bull., 81:1061-1078.

Droxler, A., and Schlager, W., in press. Glacial/interglacial sedimentation rates and turbidite frequency in the Bahamas. Geology.

Freeman-Lynde, R., Cita, M. B., Jadoul, F., Miller, E. L., and Ryan, W. B. F., 1981. Marine geology of the Bahama Escarpment. Mar. Geol., 44:119-156.

Gartner, S., 1977. Calcareous nannofossil biostratigraphy and revised zonation of the Pleistocene. Mar. Micropaleontol., 2:1-25.

Halley, R. B., Pierson, B. J., and Schlager, W., 1984. Alternative diagenetic models for Cretaceous talus deposits, Deep Sea Drilling Project Site 536, Gulf of Mexico. In Buffler, R. T., and Schlager, W., et al., Init. Repts. DSDP, 77: Washington (U.S. Govt. Printing Office), 397408.

Harland, W. B., Cox, A. V., Llewellyn, P. G., Pickton, C. A. G., Smith, A. G., and Walters, R., 1982. A Geologic Time Scale: Cambridge (Cambridge Univ. Press).

Hollister, C. D., Ewing, J. I., et al., 1972. Init. Repts. DSDP, 11: Washington (U.S. Govt. Printing Office).

Hollister, C. D., et al., 1972. Site 98-Northeast Providence Channel. In Hollister, C. D., Ewing, J. I., et al., Init. Repts. DSDP, 11: Washington (U.S. Govt. Printing Office), 9-50.

Hottinger, L., 1972. Campanian larger foraminifera from Site 98, Leg 11 of the Deep Sea Drilling Project (Northwest Providence Channel, Bahama Islands). In Hollister, C. D., Ewing, J. I., et al., Init. Repts. DSDP, 11: Washington (U.S. Govt. Printing Office), 595-606.

Paulus, F. J., 1972. The geology of Site 98 and the Bahama Platform. In Hollister, C. D., Ewing, J. I., et al., Init. Repts. DSDP, 11: Washington (U.S. Govt. Printing Office), 877-897.

Schlager, W., and Ginsburg, R. N., 1981. Bahama carbonate platformsthe deep and the past. Mar. Geol., 44:1-24.

Sheridan, R. E., Crosby, J. T., Bryan, G. M., and Stoffa, P. L., 1981. Stratigraphy and structure of southern Blake Plateau, northern Florida Straits, and northern Bahama Platform from multichannel seismic reflection data. AAPG Bull., 65:2571-2593.

Westaway, P., Hertzog, R., and Plasek, R., 1980. The gamma spectrometer tool inelastic and capture gamma-ray spectroscopy for reservoir analysis. Soc. Pet. Eng. 9461.

Zemmels, I., Cook, H. E., and Hathaway, J. C., 1972. X-ray mineralogy studies-Leg 11. In Hollister, C. D., Ewing, J. I., et al., Init. Repts. DSDP, 11: Washington (U.S. Govt. Printing Office), 729-790. 

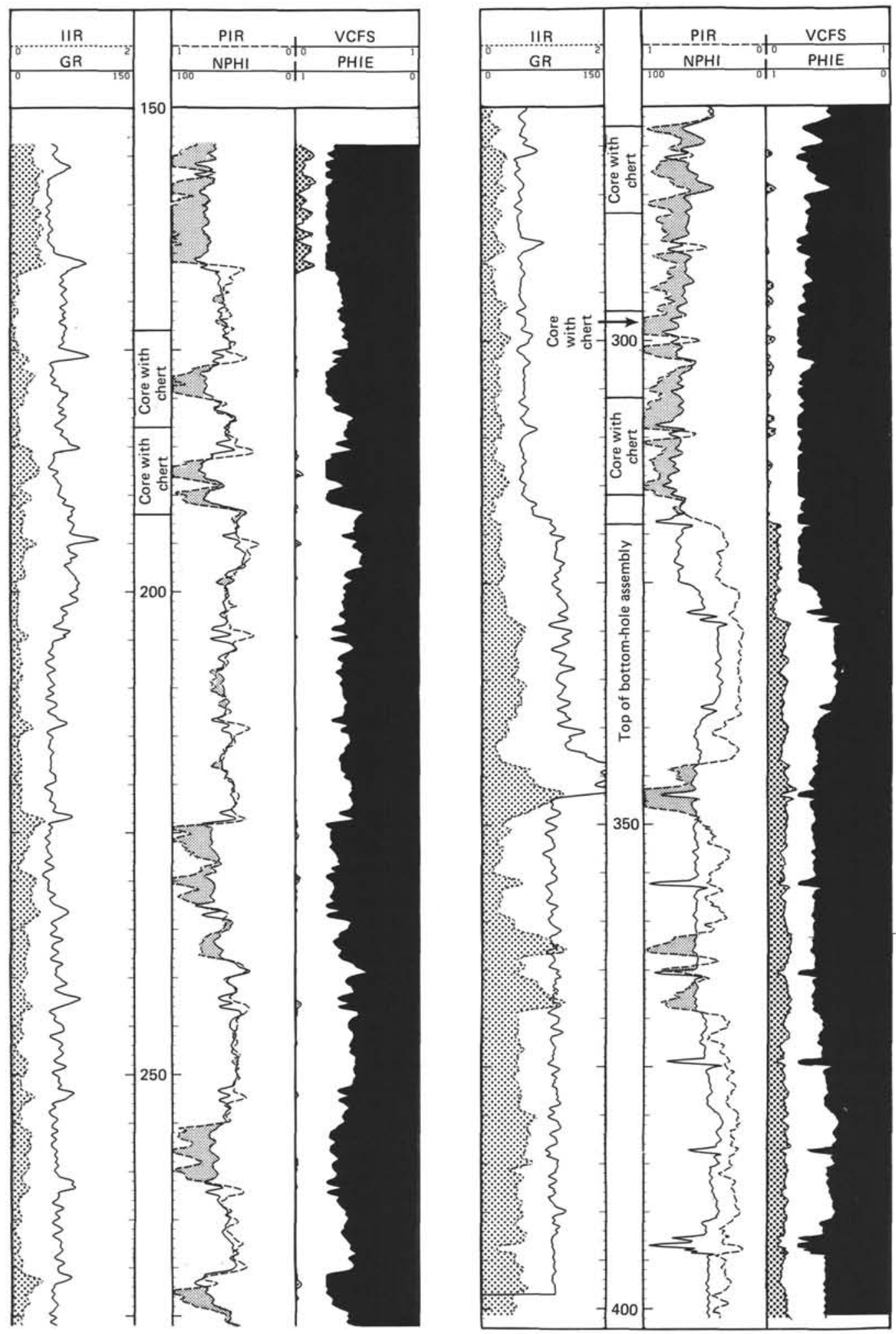

Figure 24. Ratio and lithology curves generated by the Quicklook program. The ratios are the same as in Figure 23. In the right columns, the solid-black area indicates the percentage of porosity, the blank area indicates calcite, and the stippled area indicates zones of chert. The difference between PIR and CNL porosity is used for washout determination. The locations of cores recovering chert are also indicated. Depth in meters. 


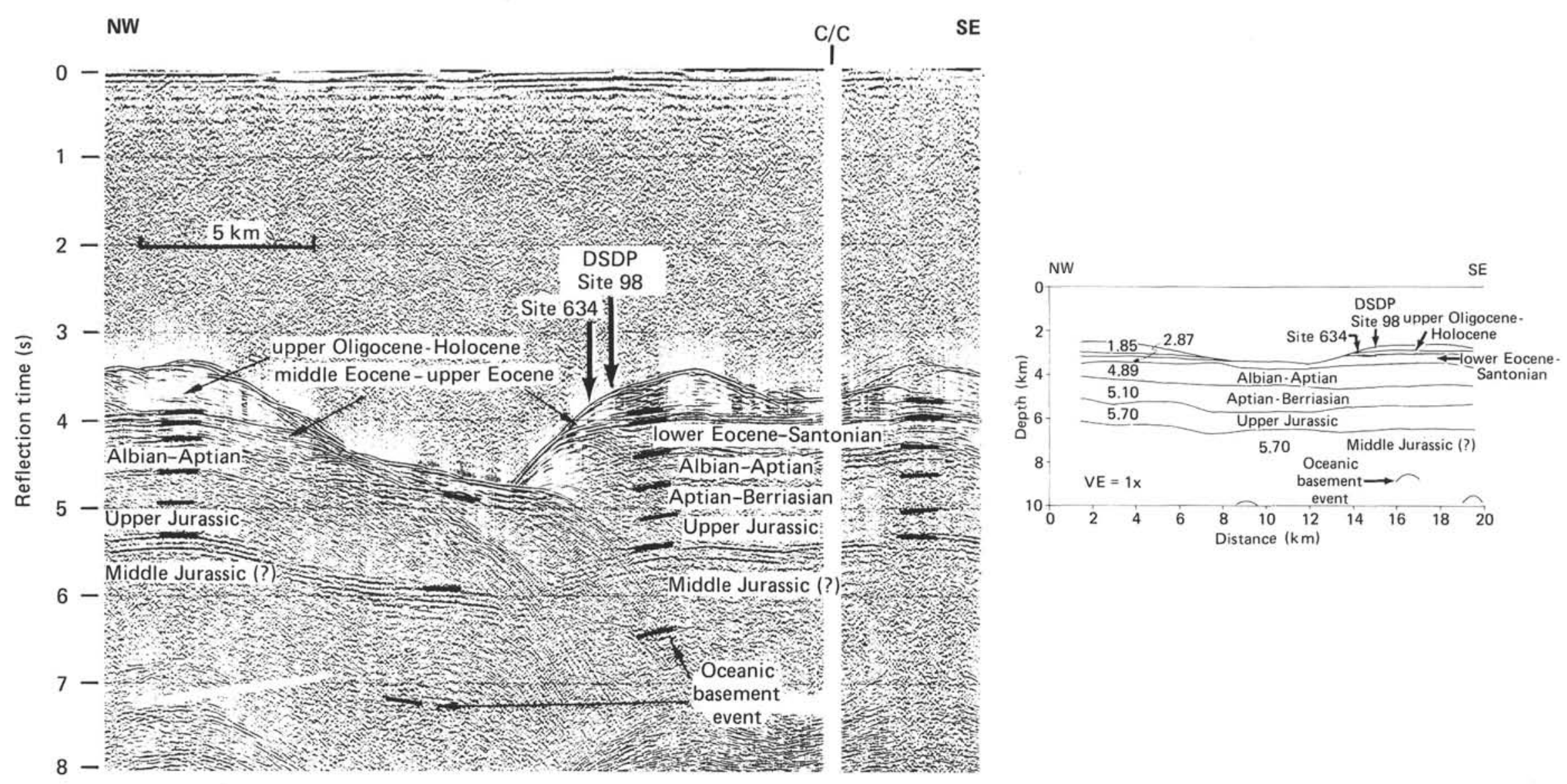

Figure 25. Interpretation of seismic line 94 in the vicinity of DSDP Site 98 and ODP Site 634 (see Fig. 3). Inset: line drawing showing velocities used for time-to-depth conversions. After Sheridan et al. (1981). 


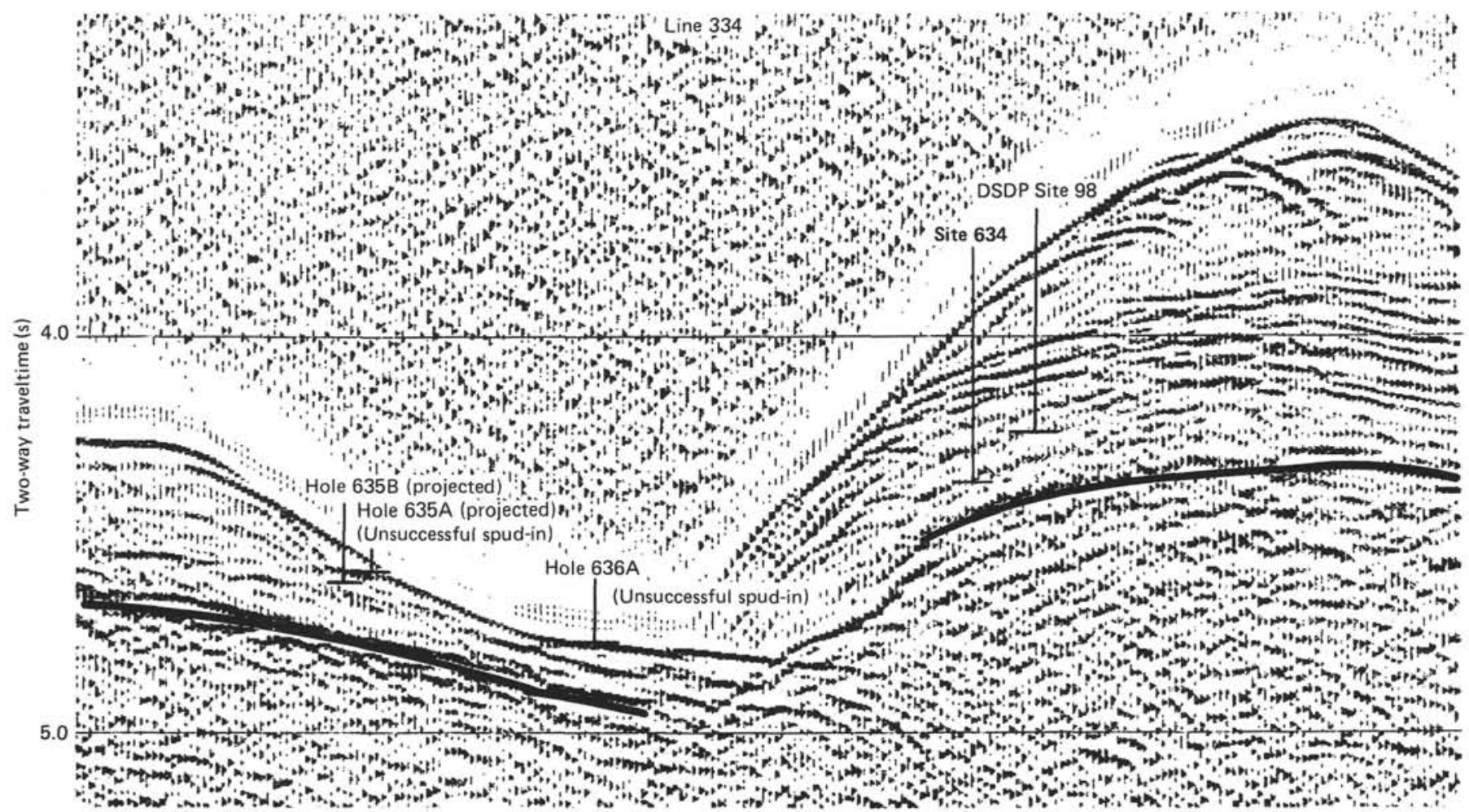

Figure 26. Spatial relationships of Sites 635 and 636 and DSDP Site 98 on line 334 (see Fig. 3). Inferred platform top is indicated by heavy line. After Sheridan et al. (1981). 


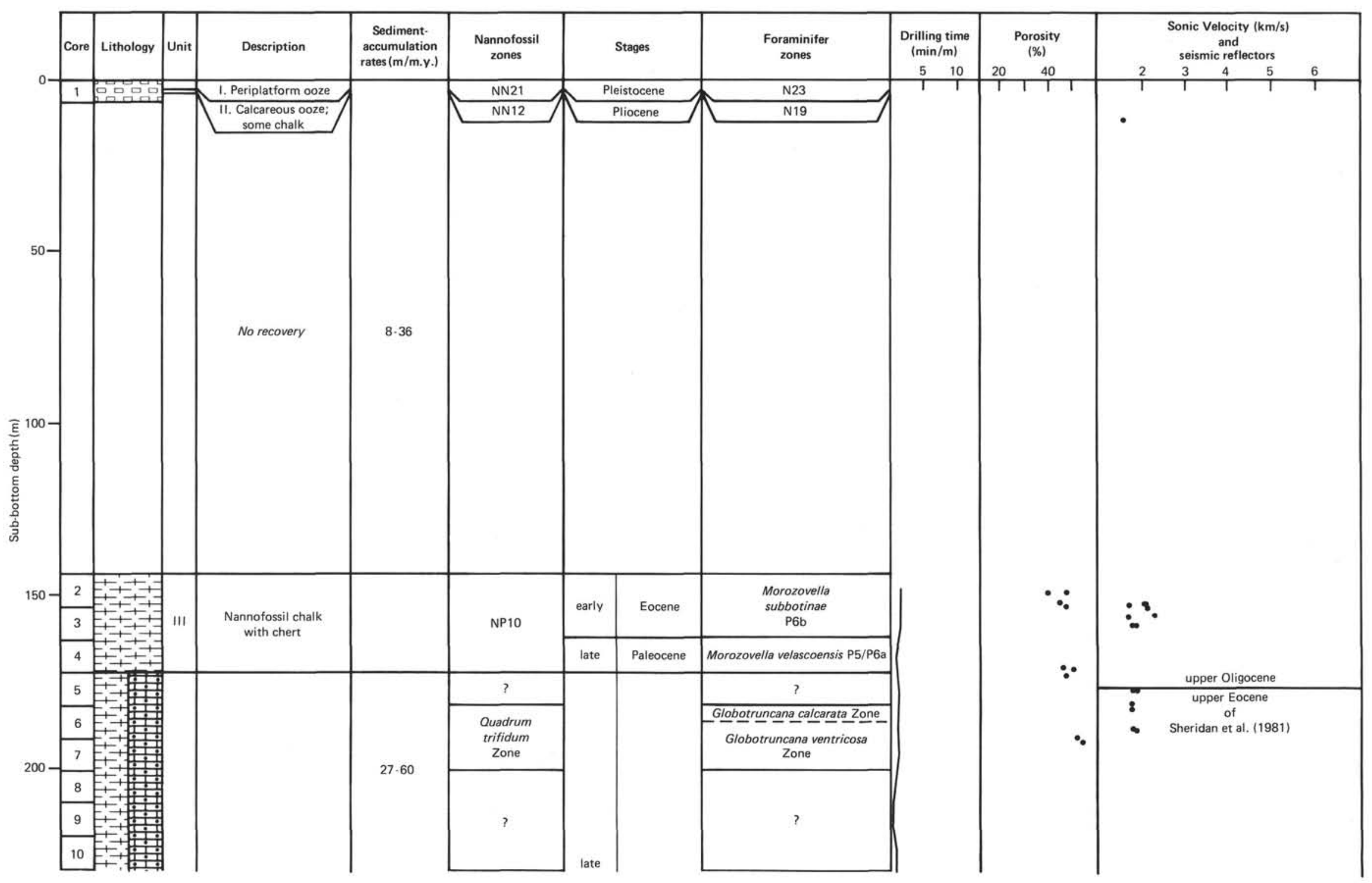




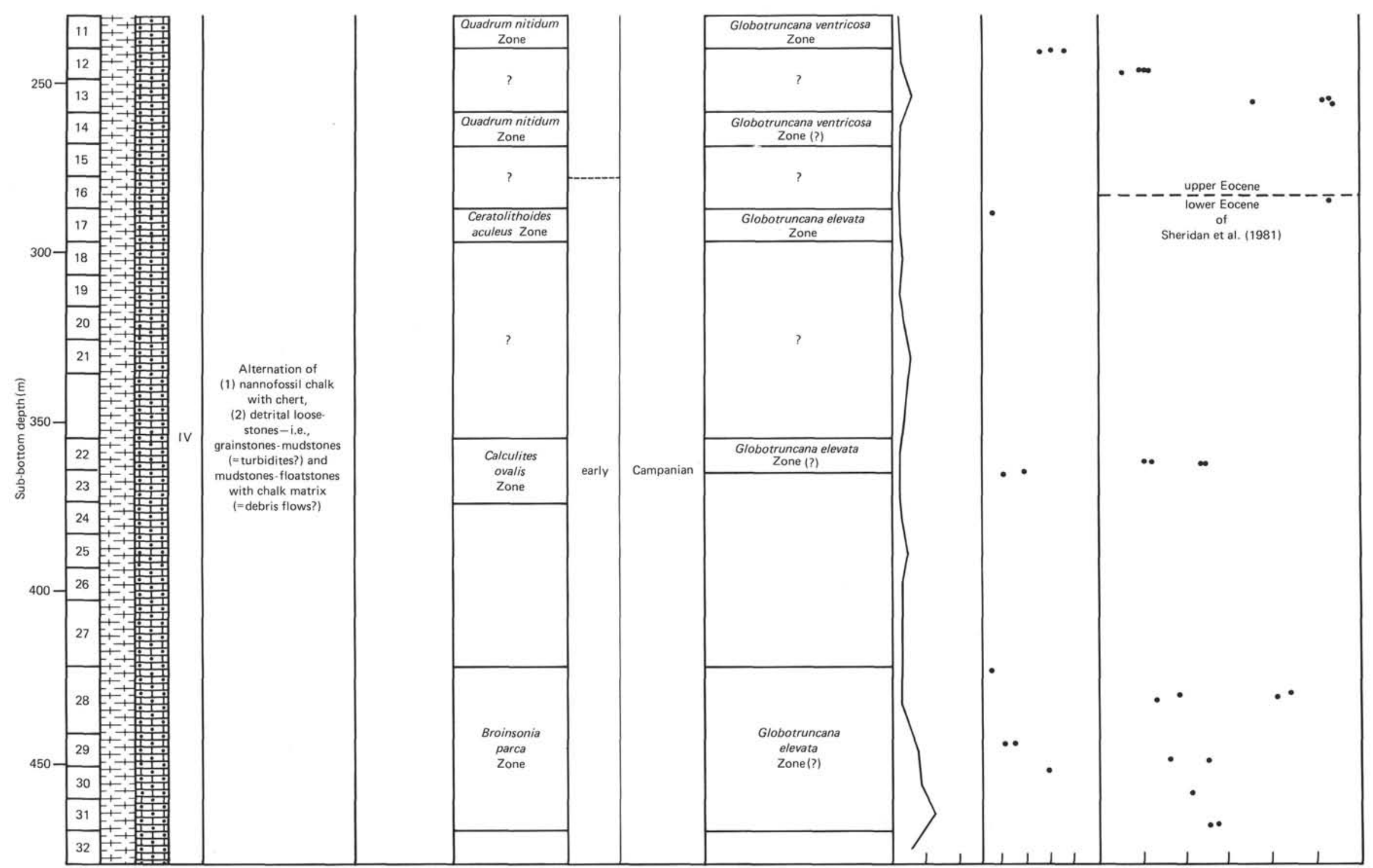

Figure 27. Summary of data for Site 634. 

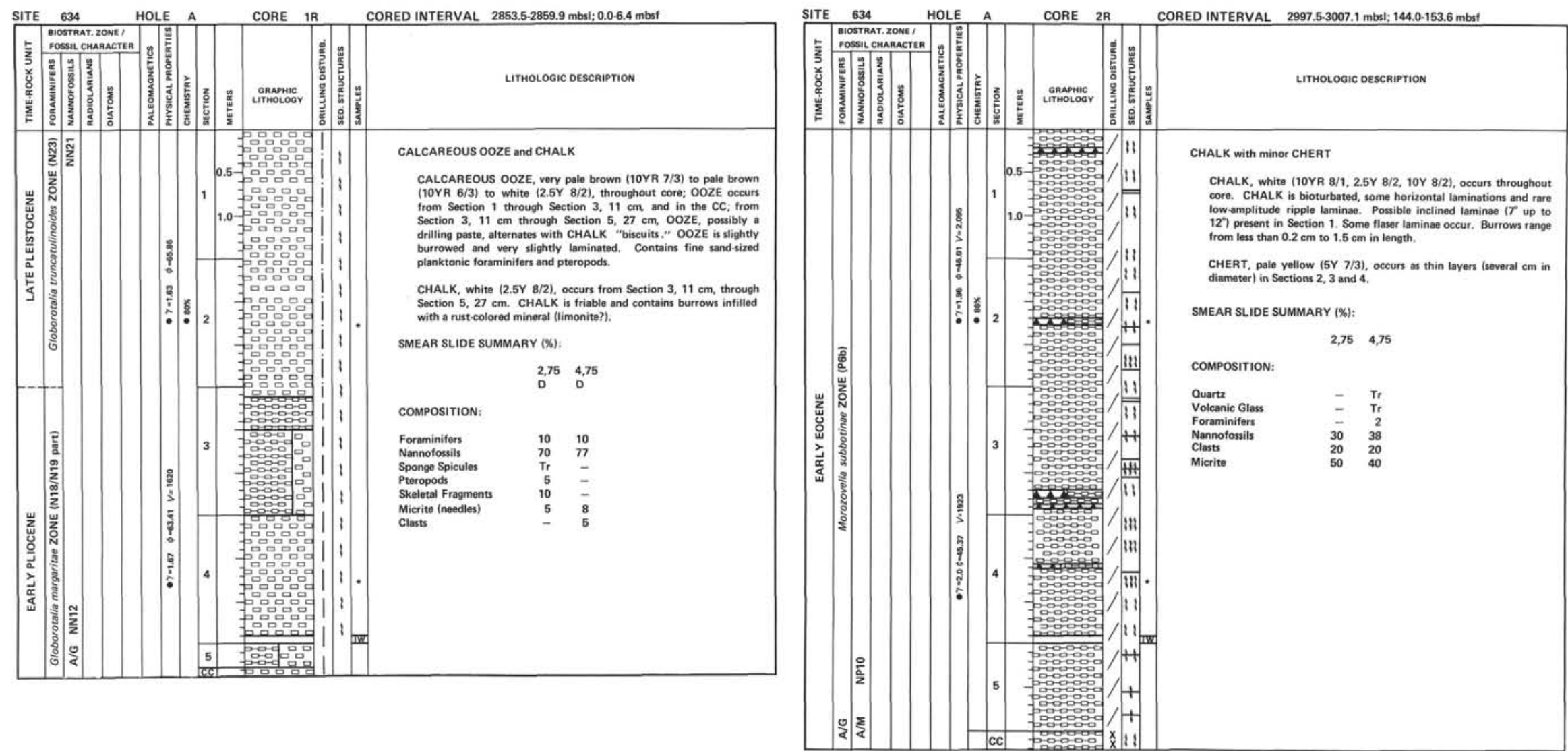


\begin{tabular}{|l|l|l|l|l|l|l|l|}
\hline SITE & 634 & \\
\hline
\end{tabular}
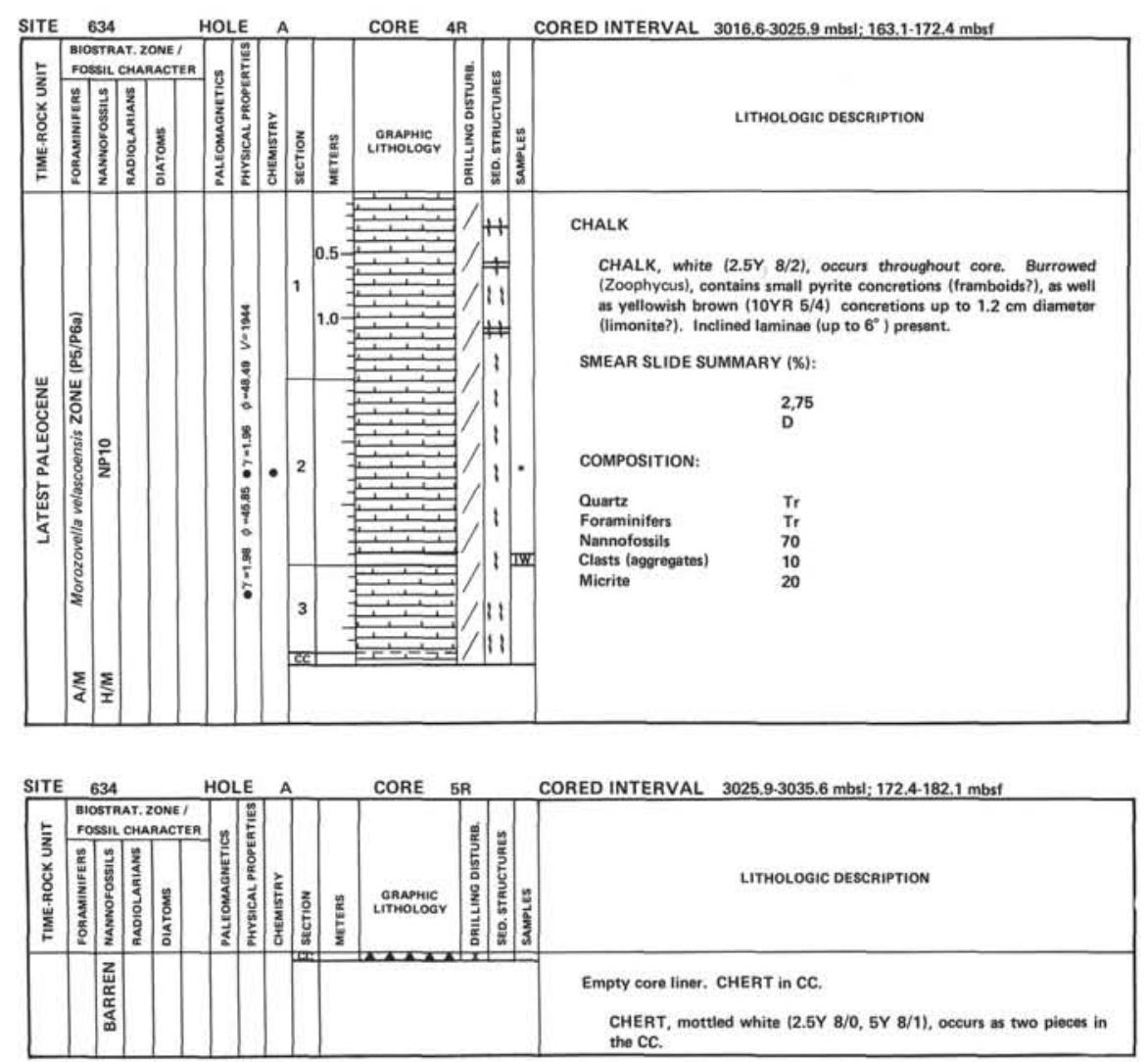
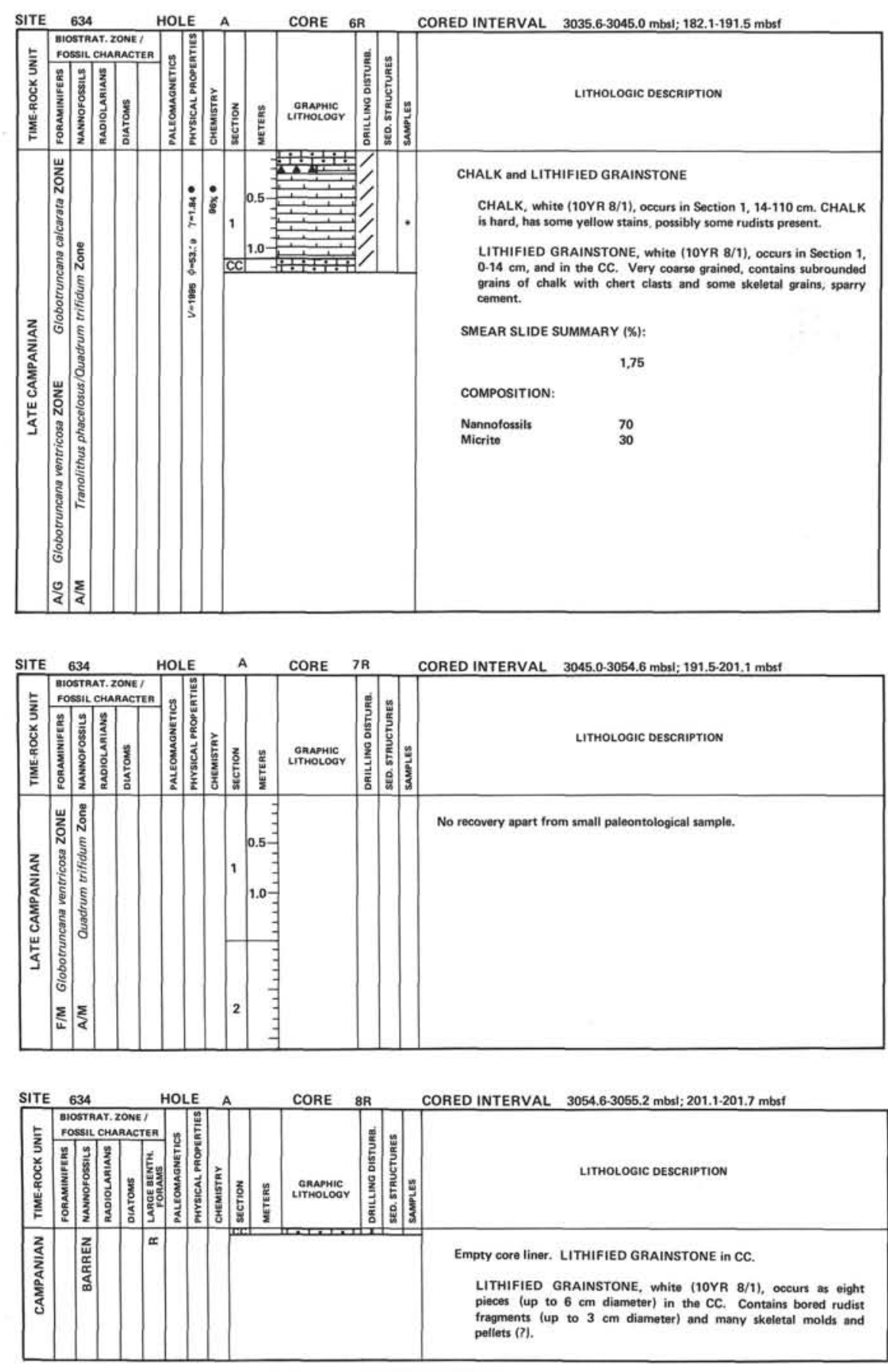

CORE 9 NO RECOVERY 

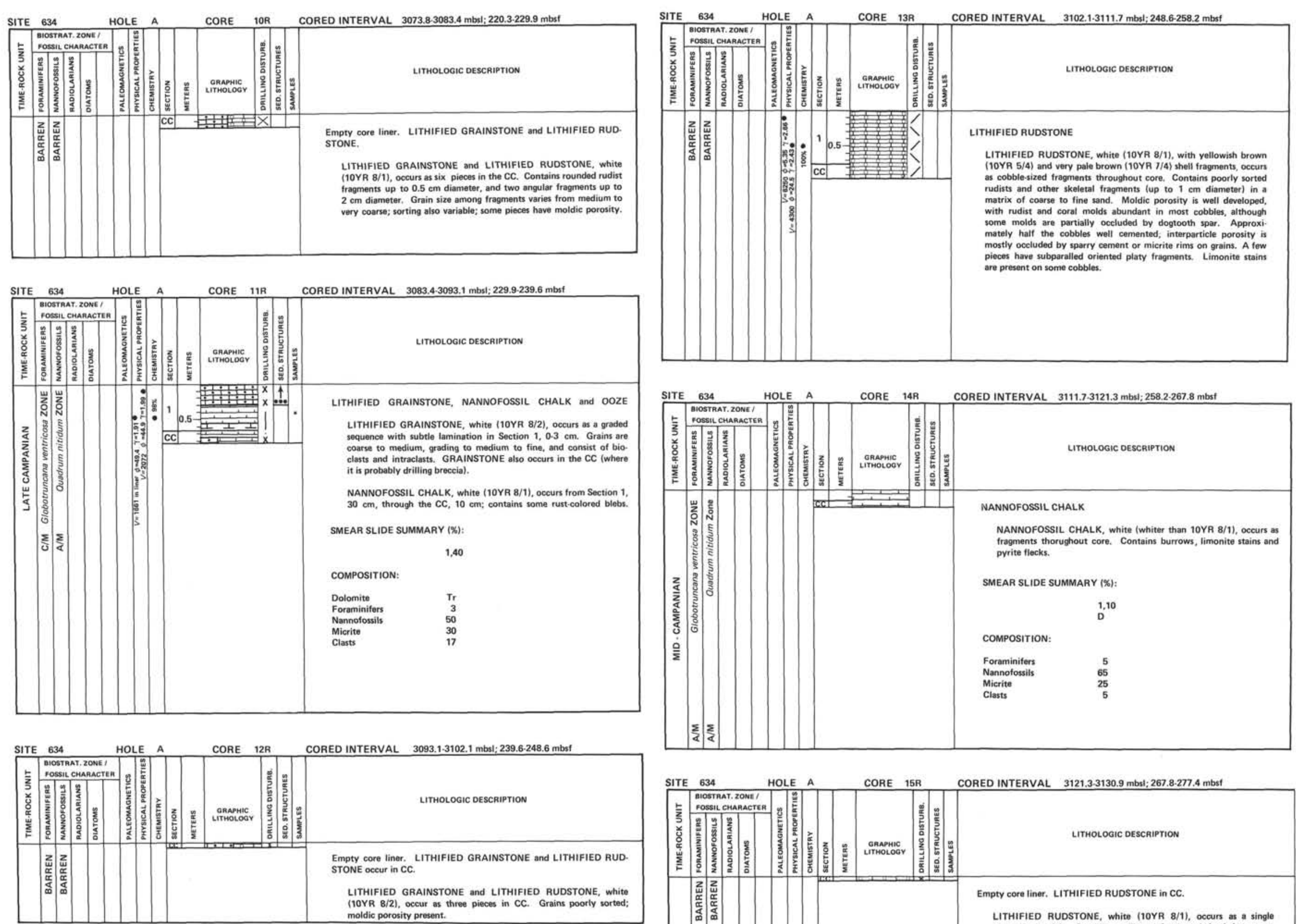

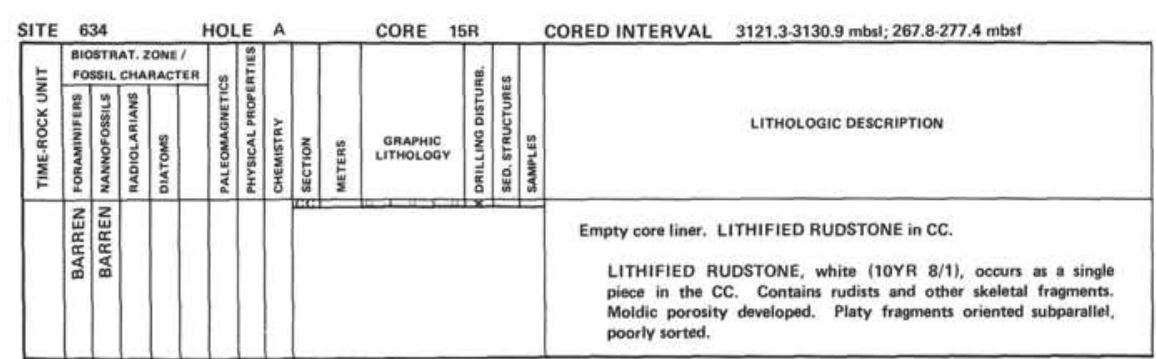



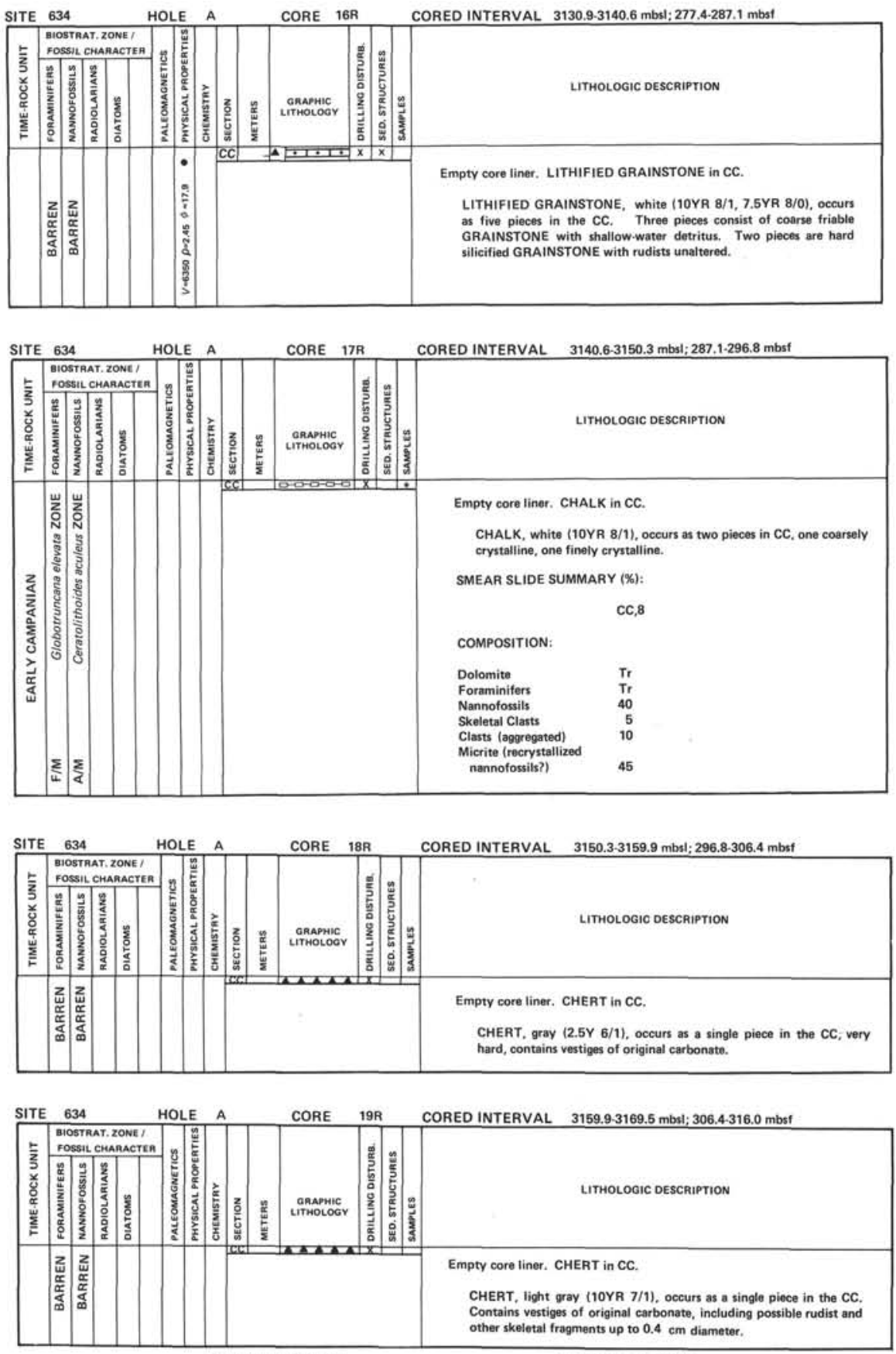
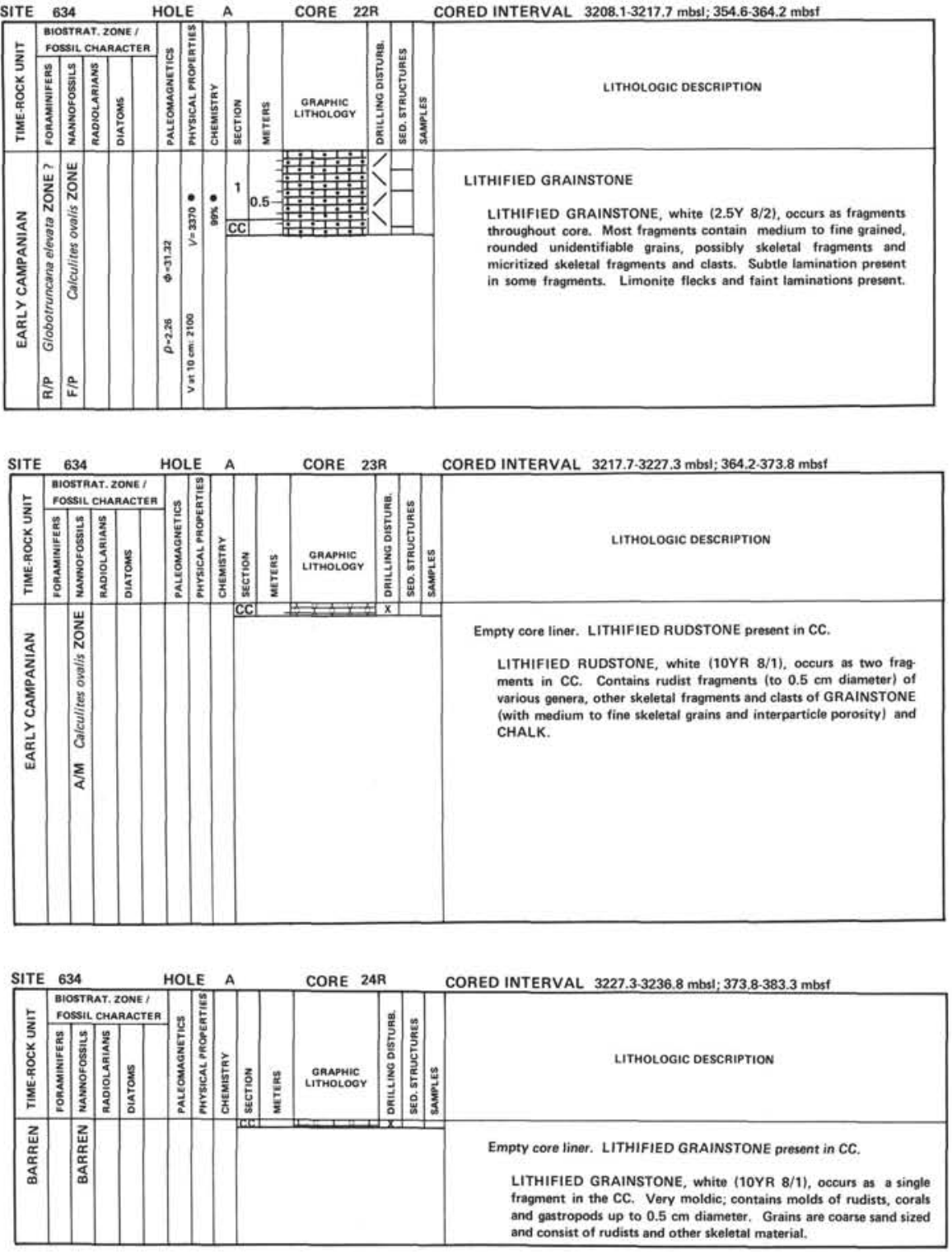

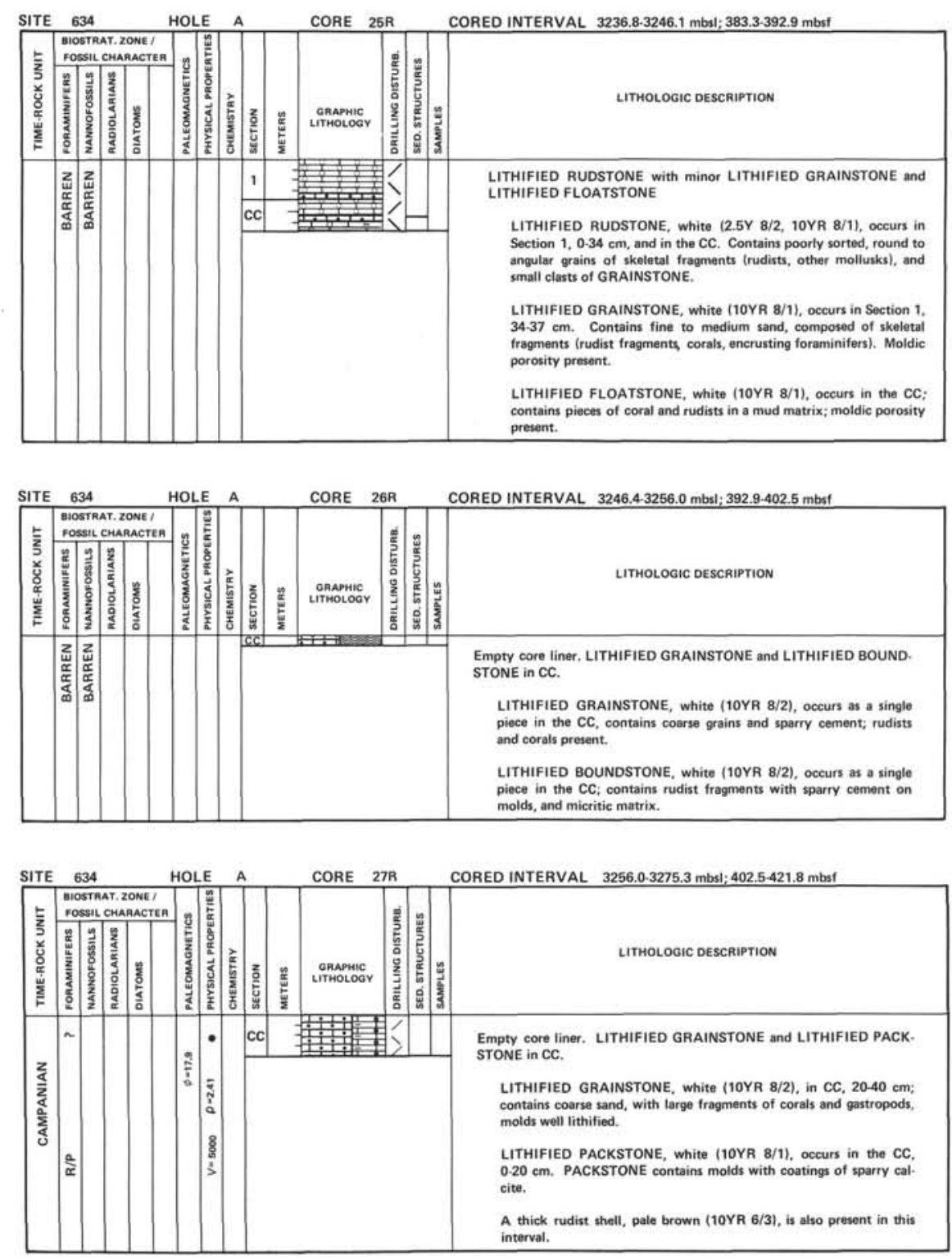
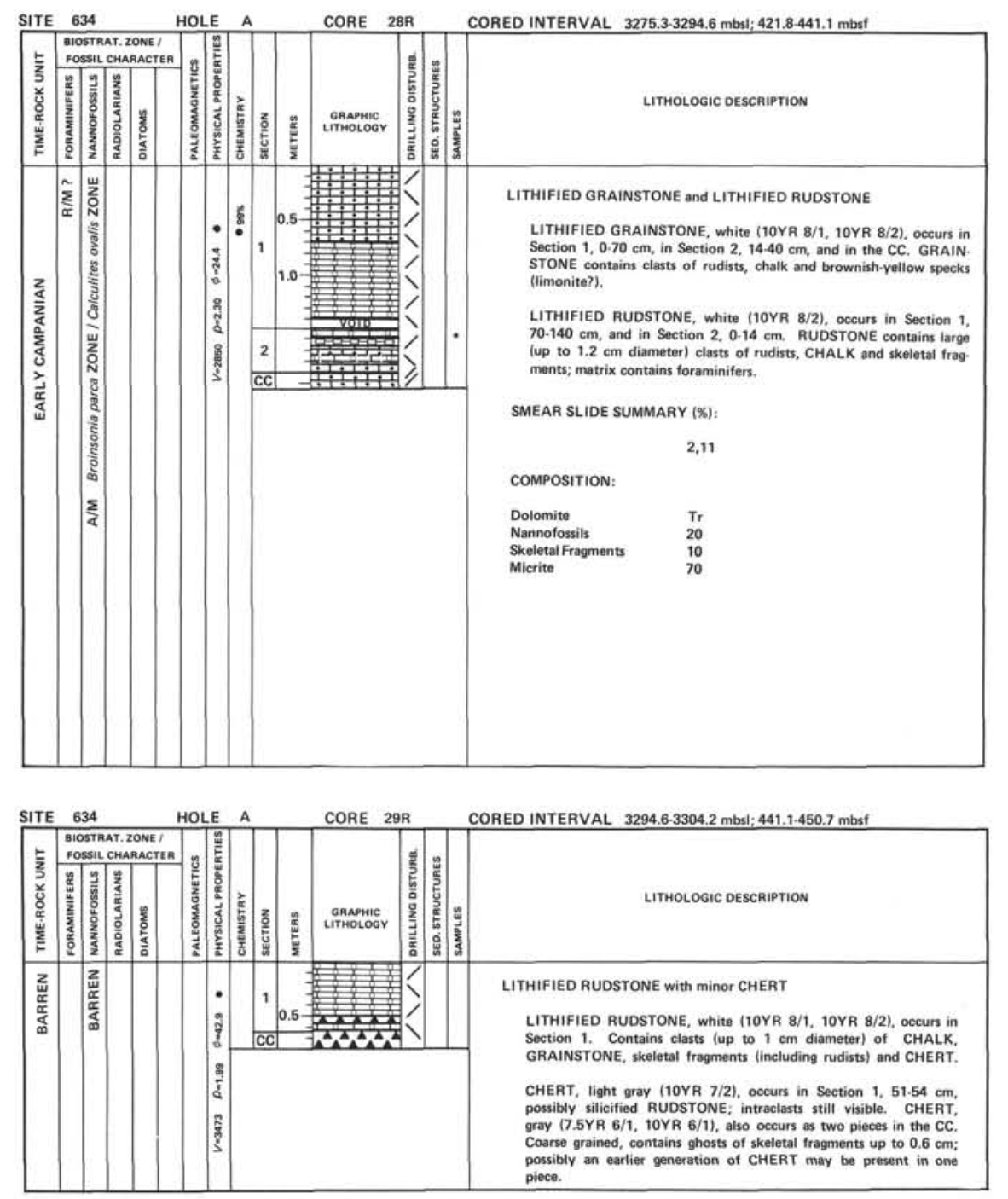


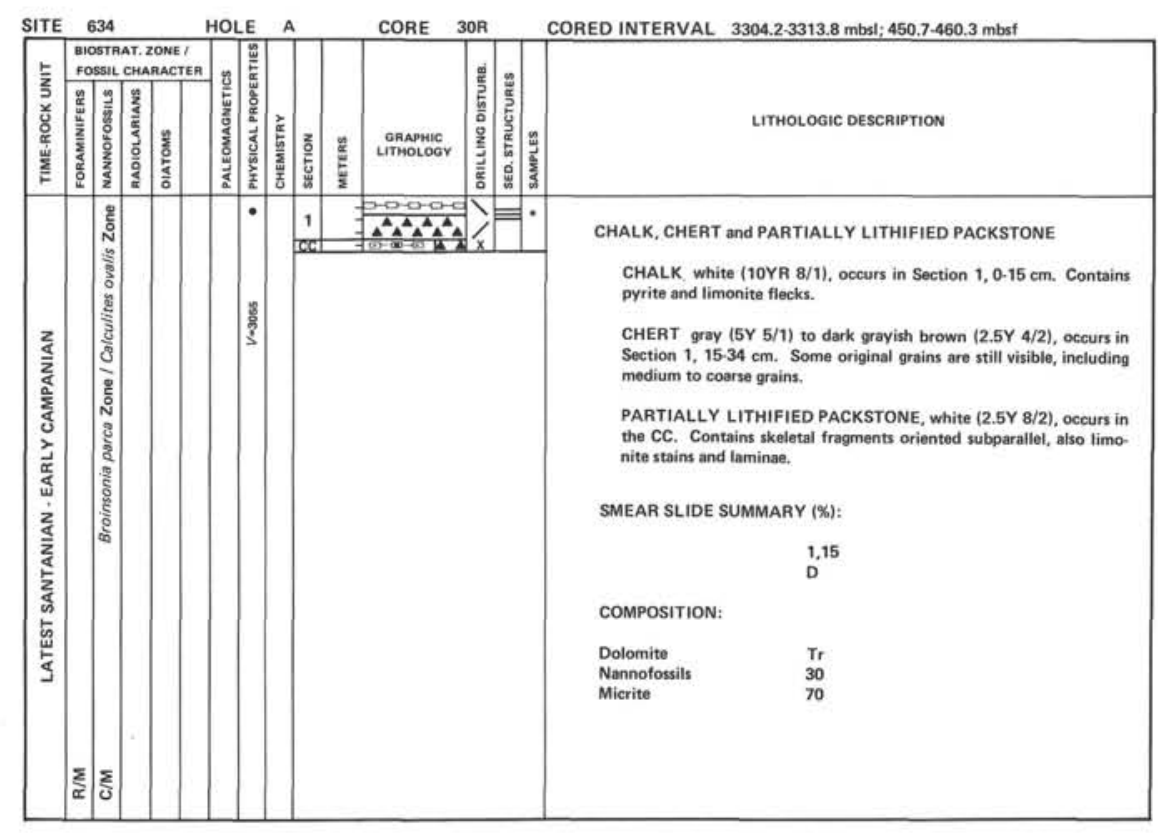

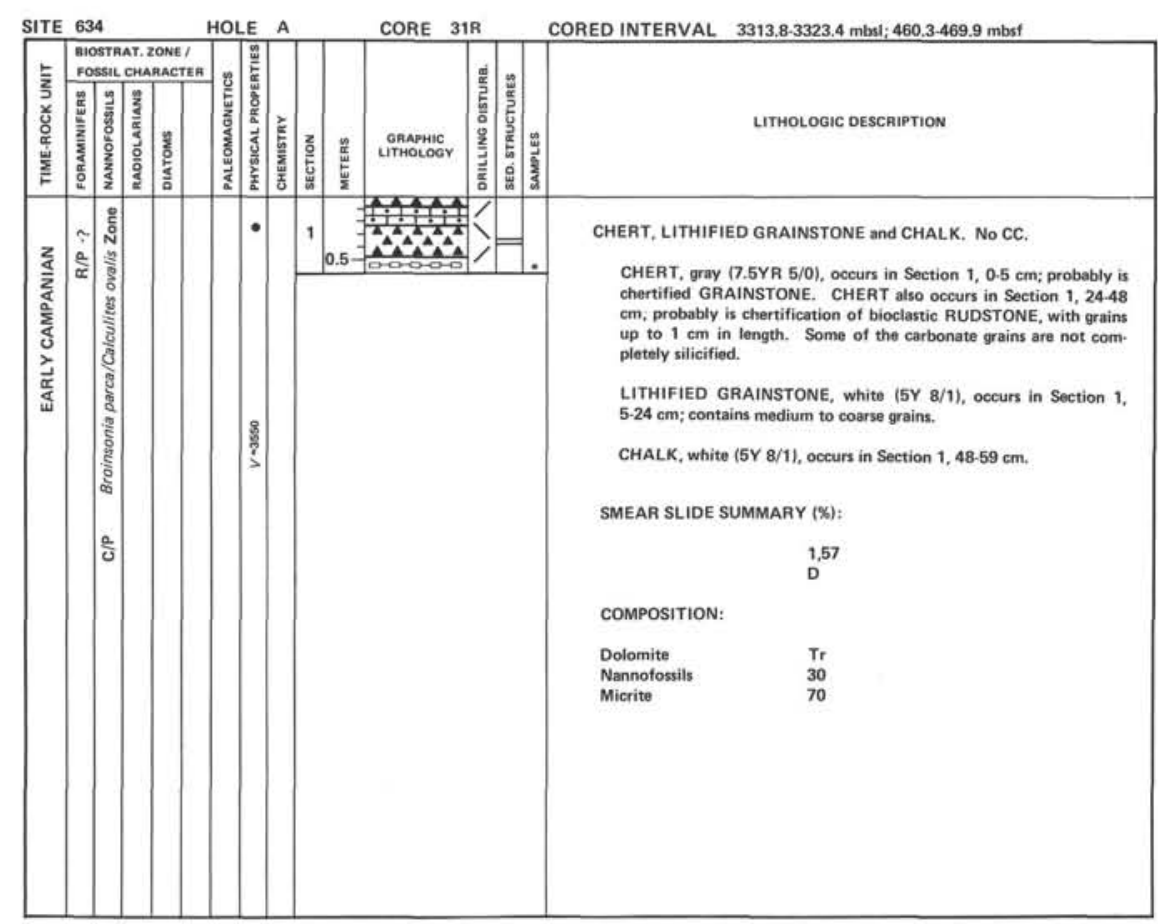

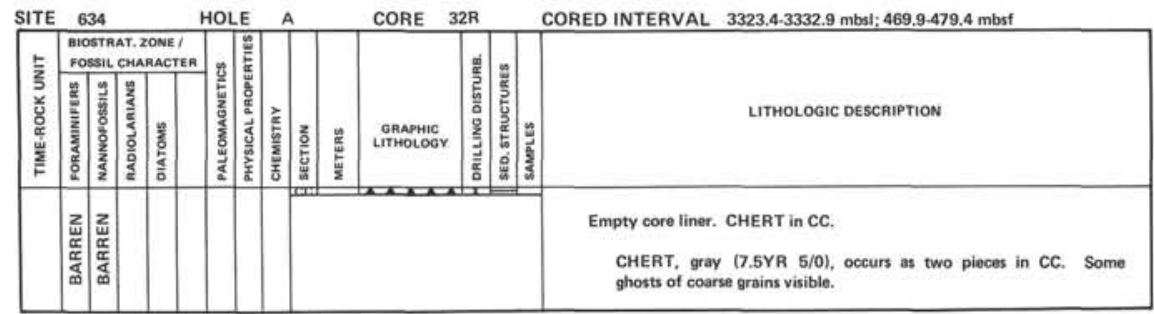




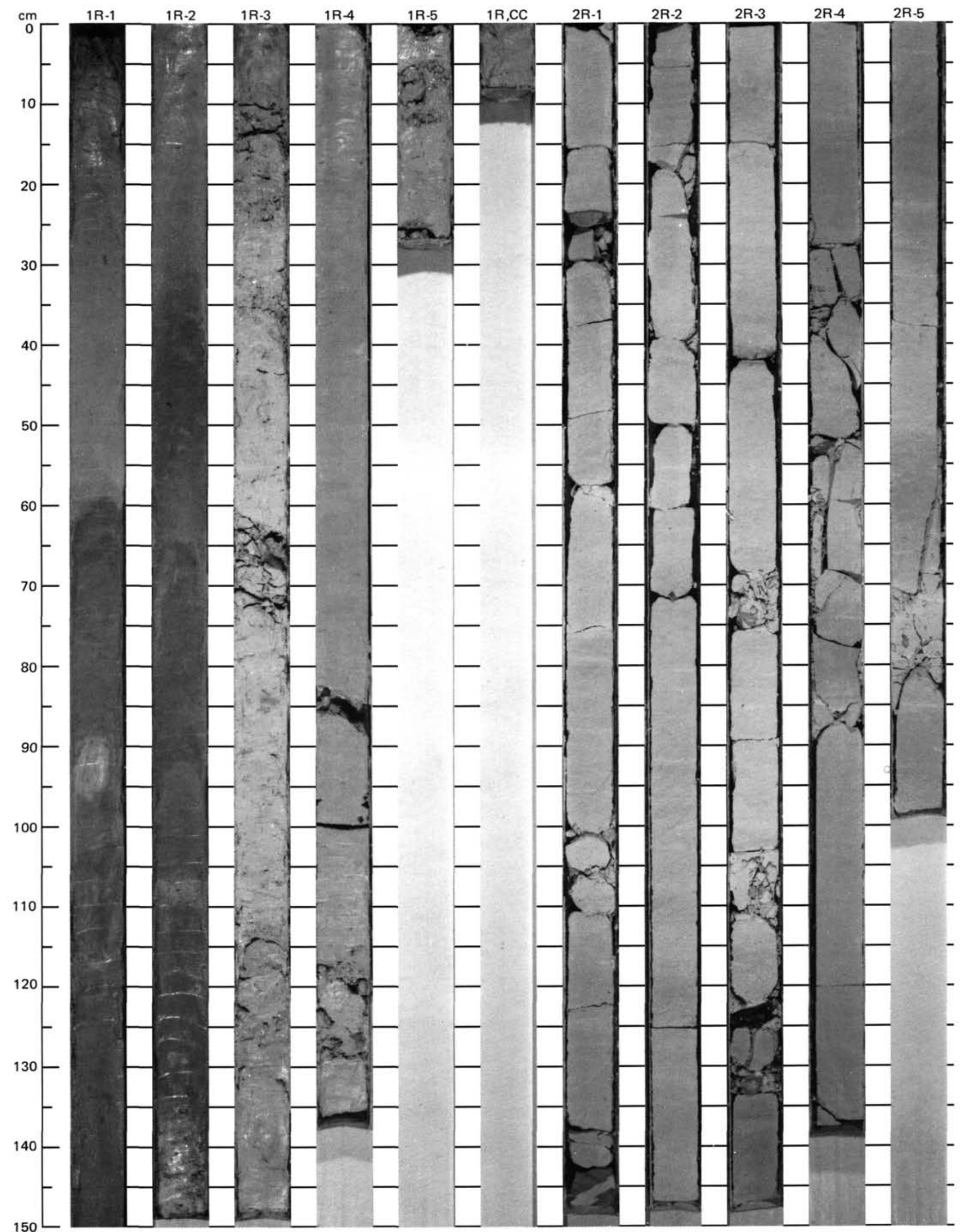




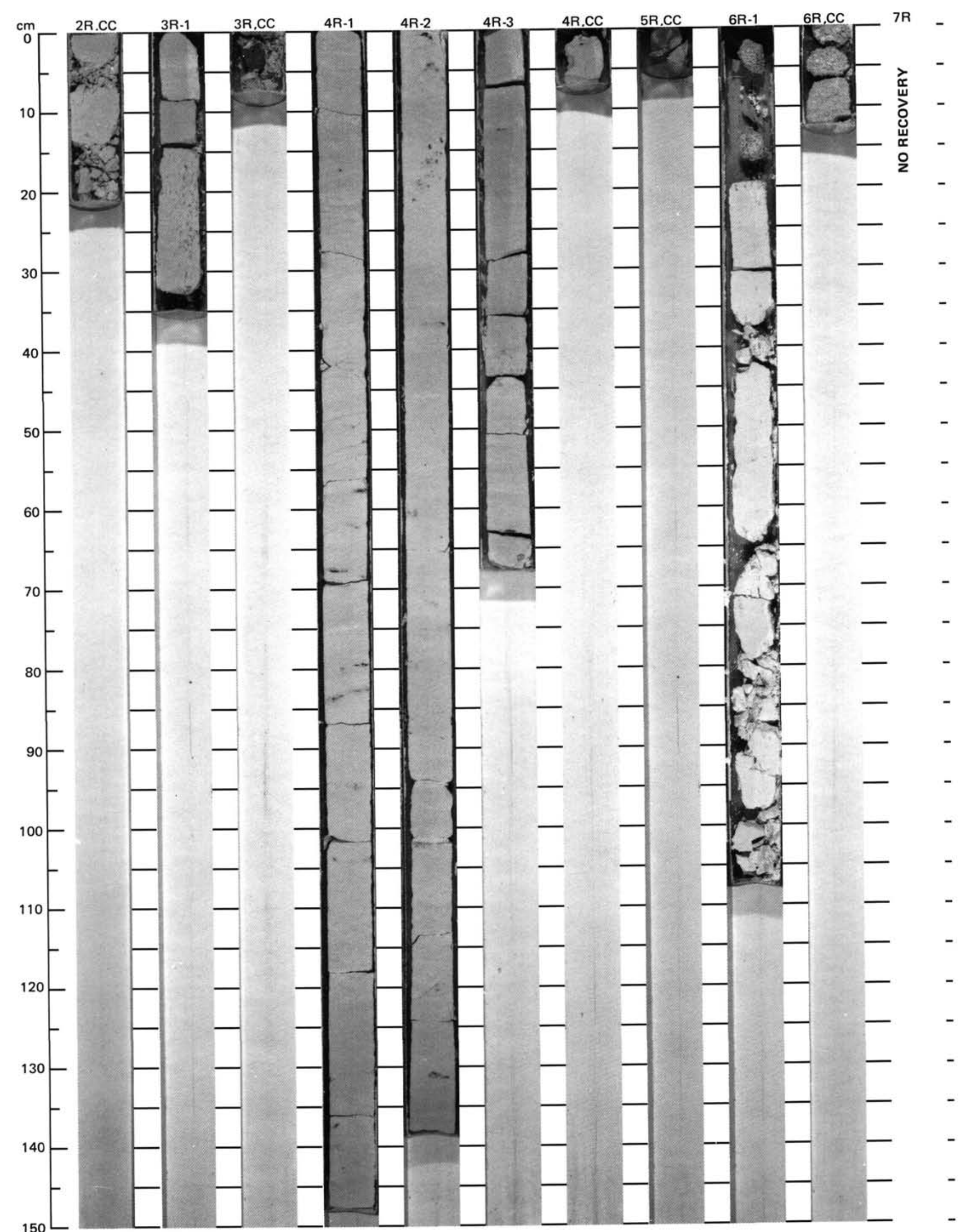


SITE 634 (HOLE A)

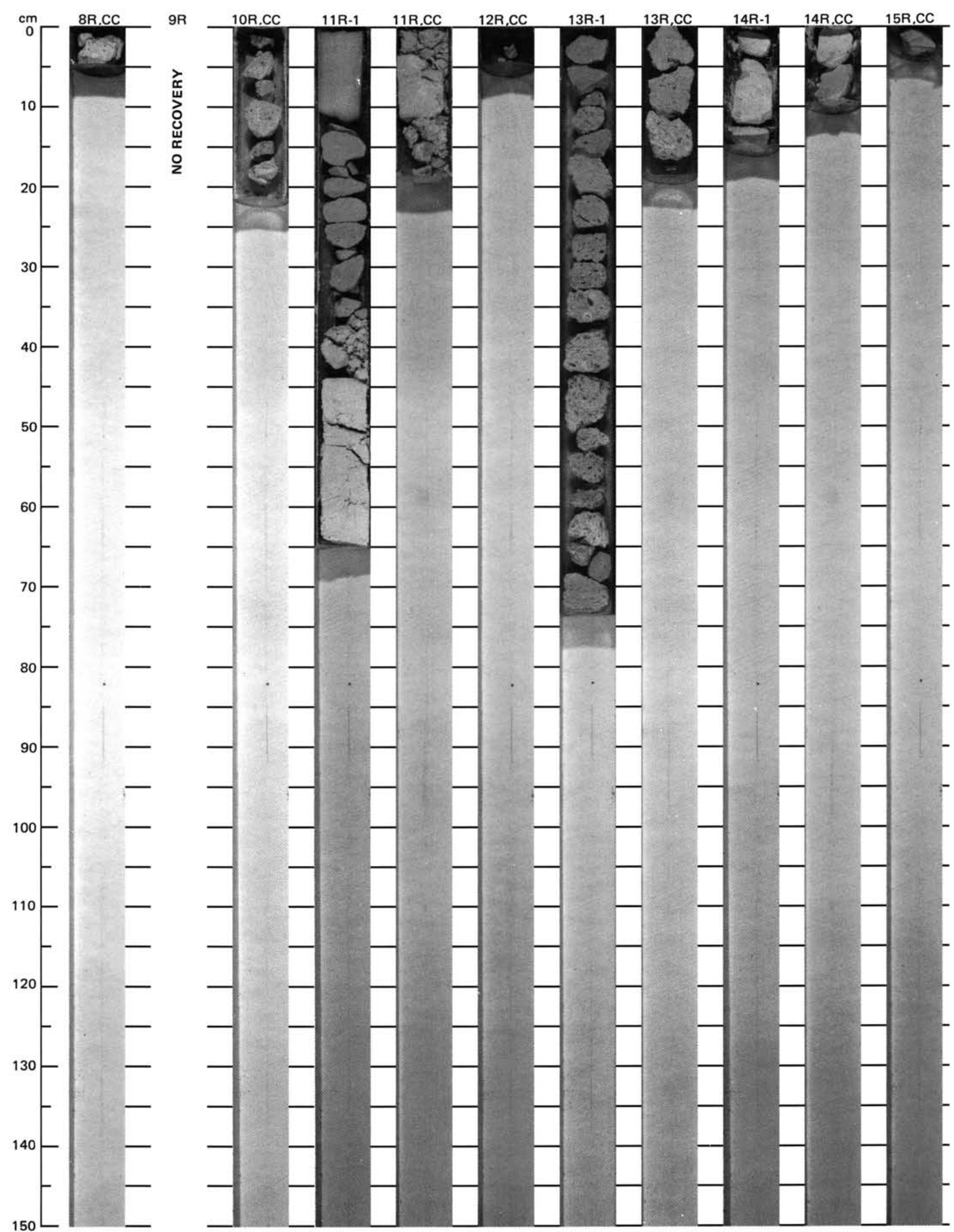




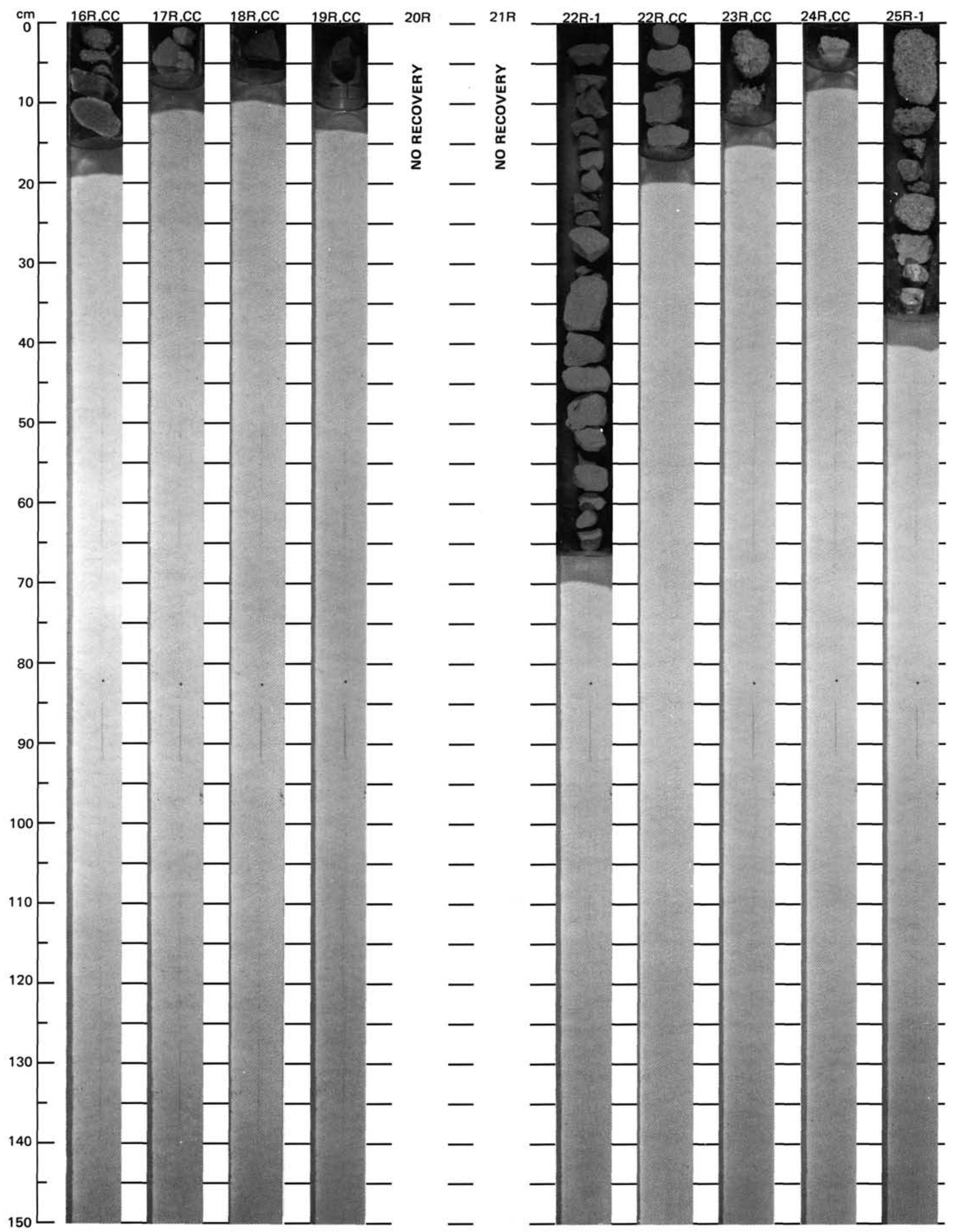




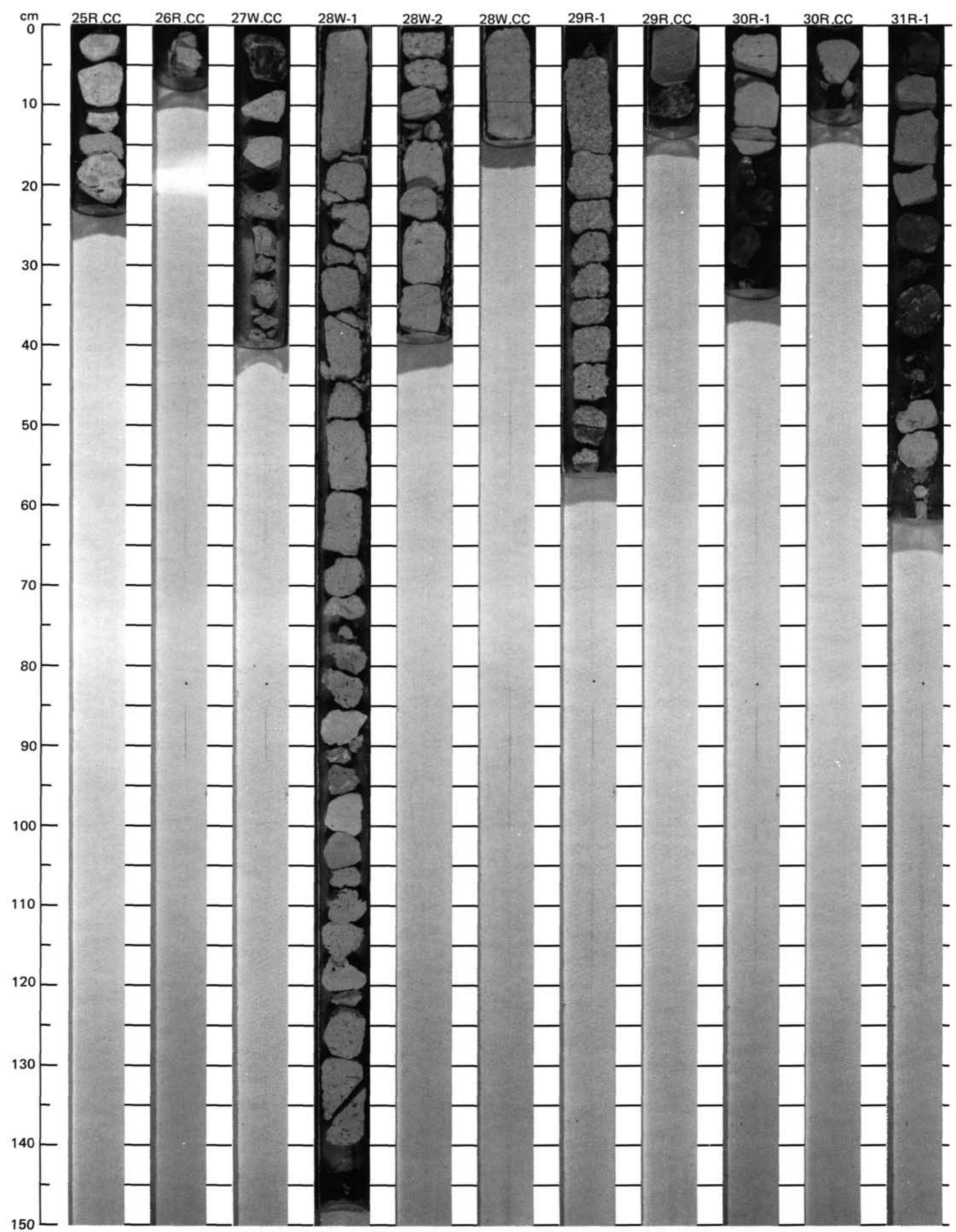




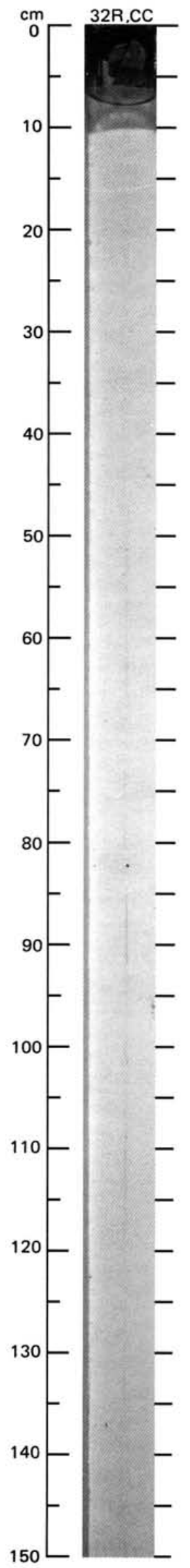

